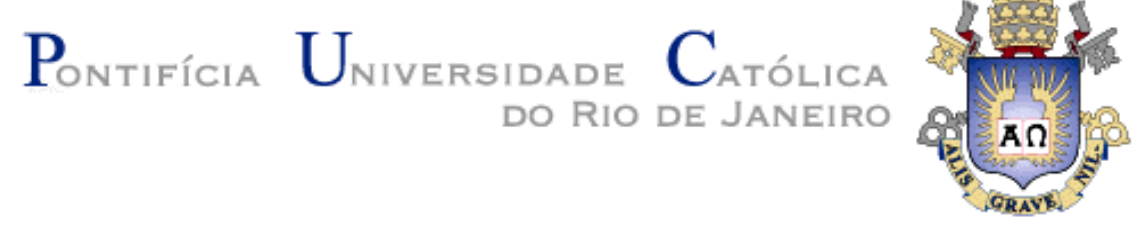

Murialdo Gasparet

Humanização na Mobilidade: evangelização nos ambientes urbanos atuais

Dissertação de Mestrado

Dissertação apresentada como requisito parcial para obtenção do grau de Mestre pelo Programa de Pósgraduação em Teologia do Departamento de Teologia da PUC-Rio.

Orientador: Prof. Joel Portella Amado

Rio de Janeiro, Março de 2013 


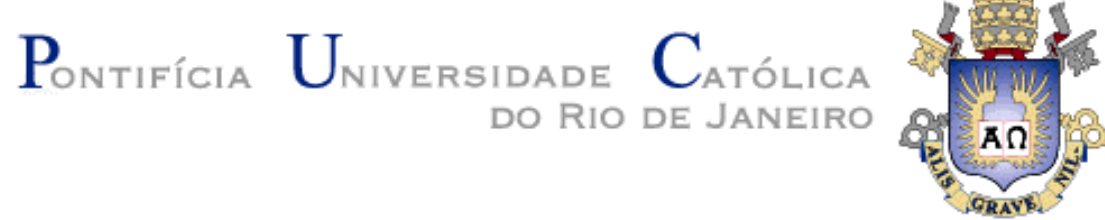

Murialdo Gasparet

Humanização na Mobilidade: evangelização nos ambientes

urbanos atuais

Dissertação apresentada como requisito parcial para obtenção do grau de Mestre pelo Programa de PósGraduação em Teologia do Departamento de Teologia do Centro de Teologia e Ciências Humanas da PUC-Rio. Aprovada pela Comissão Examinadora abaixo assinada.

Prof. Joel Portella Amado Orientador

Departamento de Teologia - PUC-Rio

Porf. Abimar Oliveira de Moraes

Departamento de Teologia - PUC-Rio

Prof. Alcir Almeida de Souza

Centro Evangélico de Missões

Prof. a Denise Berrueze Portinari

Coordenador Setorial de Pós-Graduação e Pesquisa do Centro de

Teologia e Ciências Humanas

Rio de Janeiro, 22 março de 2013 
Todos os direitos reservados. É proibida a reprodução total ou parcial do trabalho sem autorização da universidade, do autor e do orientador.

\section{Murialdo Gasparet}

Sacerdote. Graduou-se em Teologia na PUC-RS. Cursou Filosofia na Universidade Caxias do Sul (UCS). Foi um dos Membros Fundadores da Pastoral dos Nômades do Brasil (CNBB). Em 1999, publicou o O Rosto de Deus na Cultura Milenar dos Ciganos. Fez pós-graduação lato sensu em Psicologia Existencial Humanista (2009) e em Psicanálise Clínica (2011), todas pelos ISECENSA. É coordenador da Pastoral Universitária da Diocese de Campos dos Goytacazes, membro da comissão de ética e pesquisa CEP/Conep, pelo ISECENSA. Professor nos Institutos Superiores do CENSA e no Curso de Filosofia Eclesiástica Sede Sapientiae, no Seminário Maior Maria Imaculada - Diocese de Campos do GoytacazesRJ.

Ficha Catalográfica

Gasparet, Murialdo

Humanização na mobilidade: evangelização nos ambientes urbanos atuais / Murialdo Gasparet ; orientador: Joel Portella Amado. - 2013. $147 \mathrm{f}$; $30 \mathrm{~cm}$

Dissertação (mestrado)-Pontifícia Universidade Católica do Rio de Janeiro, Departamento de Teologia, 2013

Inclui bibliografia

1. Teologia - Teses. 2. Mobilidade. 3. Humanização. 4. Urbano. 5. Evangelização. I. Amado, Joel Portella. II. Pontifícia Universidade Católica do Rio de Janeiro. Departamento de Teologia. III. Título. 
Fixo o olhar em Deus. Nele creio, espero, amo, confio, agradeço e caminho. 


\section{Agradecimentos}

Aos meus pais, dos quais recordo com saudade, transmitiram-me o dom da vida e plantaram, pela educação, as sementes do bem, do respeito e da justiça. Por seus exemplos de cuidado, afeto, bondade e ternura, ensinaram-me valores cristãos.

Ao CNPq e à PUC-Rio, pelos auxílios concedidos, sem os quais este trabalho não poderia ter sido realizado.

Ao meu orientador e amigo, Prof. Joel Portella Amado, pela dedicação, maturidade e entusiasmo partilhados ao longo deste Mestrado.

Às Irmãs Salesianas Filhas de Maria Auxiliadora de Campos dos Goytacazes, a Suely Lemos, Ricardo e Mairse Teixeira, Elizabeth Landin, Paula Sousa, e a todos os amigos pela amizade, confiança e incentivo nessa caminhada.

Aos professores que me enriqueceram com os seus conhecimentos e dons, todos indispensáveis para minha formação.

Aos professores que participaram da Comissão Examinadora Prof. Joel Portella Amado, Prof. Abimar Oliveira de Moraes e Prof. Alcir Almeida de Souza.

Aos meus colegas de curso e funcionários desta Universidade, que por meio dos trabalhos e gestos mais simples, foram instrumentos de ensino e acolhida.

A todos os homens e mulheres de boa vontade que constroem um mundo melhor, com palavras, atos e ações. 


\section{Resumo}

Gasparet, Murialdo; Amado, Joel Portella. Humanização na Mobilidade: evangelização nos ambientes urbanos atuais. Rio de Janeiro, 2013. 147p. Dissertação de Mestrado - Departamento de Teologia, Pontifícia Universidade Católica do Rio de Janeiro.

A presente dissertação pretende analisar alguns aspectos do ser humano à luz da concepção da antropologia teológica cristã e suas implicações, especialmente no que diz respeito à mobilidade urbana atual. Pretende-se demonstrar as várias formas de nomadismo urbano da atualidade e suas características marcantes, como a transitoriedade como um fenômeno humano no ambiente social, afetivo e religioso; o anonimato e a perda de identidade nas grandes cidades, que gera uma insatisfação social, bem como mostrar que o ser humano é capaz de fazer a experiência cristã nos ambientes de mobilidade atual. Ressaltar-se-á a importância da adoção de uma proposta pastoral para as novas referências culturais marcadas por esse contexto. Esse trabalho também pretende fazer uma reflexão sobre alguns aspectos positivos do nomadismo urbano atual, como a superação do individualismo e outros considerados negativos, como o perigo do ser humano tornar-se fragmentado e coisificado. Isso obriga a pensar em que sentido a mobilidade urbana atual favorece aos processos de humanização. Assim, é de extrema importância possibilitar o encontro do ser humano com o Deus de Jesus Cristo nos ambientes em que a vida vem se tornando uma experiência notoriamente móvel.

\section{Palavras-chave}

Mobilidade; humanização; urbano; evangelização. 


\section{Abstract}

Gasparet, Murialdo; Amado, Joel Portella (Advisor). Humanization in Mobility: evangelization in today's urban environments. Rio de Janeiro, 2013. 147p. MSc. Dissertation - Departamento de Teologia, Pontifícia Universidade Católica do Rio de Janeiro.

This dissertation intends to analyze some aspects of the human being the light of conception of Christian theological anthropology and its implications, especially regarding to today's urban mobility. It is indented to show many ways of current urban nomadism and their outstanding characteristics, such as the transitoriness as a human phenomenon in social, affective and religious environments; the anonymity and identity loss in big cities, which creates a sosial dissatisfaction, as well as to show that human beigs are capable of making the Christian experience in today's urban mobility environments. It will emphasize how important is to adopt a pastoral proposal facing the new cultural references marked by this context. This work also intends to make a reflection about some positive aspects of current urban nomadism, like overcoming individualism and others aspects considered as negative, like the danger of a human become fragmented and thingified. This forces us to think in which way today's urban mobility favors the humanization process. Therefore, it is extremely important to enable human encounter with Jesus Christ's God in all environments in which life has become notoriously a mobile experience.

\section{Keywords}

Mobility; humanization; urban; evangelization. 


\section{Sumário}

Introdução

1. Nomadismo Urbano Atual 15

1.1. A cidade, sua história e uma possível compreensão 17

1.2. Sedentarismo, a vida urbana atual e a mobilidade social 19

1.3. Compreensão de urbano e processo de urbanização 22

1.4. Compreensão de nomadismo urbano 27

1.5. Perfil do ser humano nômade urbano 34

2. O Ser Humano à Luz da Antropologia Cristã -

A Mobilidade e o Ser Humano: Parâmetros 52

2.1. Criatura 55

2.2. Ser vivente 59

2.3. Capacitado para a eleição-aliança 66

2.4. Aberto positivamente aos outros 67

2.5. Aberto ao Divino e Absoluto 74

2.6. Pessoa 76

2.7. Ser que é corpo $\quad 79$

2.8. Aberto ao futuro 84

2.9. Em busca da verdade 85

2.10. Restaurado em Jesus Cristo e santificado no Espírito 87

2.11. O ser humano e a mobilidade: desafios 91

3. Mobilidade, Humanização e Evangelização 95

3.1. A pergunta trazida pela mobilidade 97

3.2. A resposta cristã 104

3.3. Implicações para a evangelização 110

$\begin{array}{ll}\text { Conclusão } & 135\end{array}$

4. Referências Bibliográficas 142 
A vida é movimento / Que nos move para perto / Ou para longe /Através do tempo / Para outros mundos / Onde a imaginação levar / Movimento pensado, inventado, sonhado / Recriado / Movimento de mudança, de forma, / De ritmo, de cenário / Ação, emoção / Além da realidade / Direção que te leva além da liberdade / 


\section{INTRODUÇÃO}

A mobilidade é uma característica marcante de nossos dias. O ser humano vive uma situação de desenraizamento constante nos espaços urbanos, uma movimentação contínua nos espaços geográficos, sociais, psicológicos e religiosos. O mobilizar urbano atual constitui um desafio para a fé cristã que se defronta com uma realidade permeada pelas incertezas, fragmentações e flutuação identitária. Assume, assim, a mobilidade, uma importância fundamental na Antropologia Teológica, pela compreensão da totalidade do ser humano, uma vez que, mais que em qualquer outro tempo, a realidade tem exigido uma movimentação intensiva nos planos sociais, políticos e afetivos.

Fixar-se é uma possibilidade da condição humana, assim como movimentar-se. No entanto, nunca as contingências dessa mobilidade afetaram tanto o ser humano como na época atual. A própria globalização nos espaços urbanos atuais acena para a abertura total desses espaços, a aceleração do ritmo de vida e a ruptura com quaisquer barreiras que tornem o ser humano limitado. A evangelização depara-se cada vez mais com a construção de novas identidades e inúmeros desafios para os processos de humanização com valores cristãos, em que o cidadão contemporâneo, alcançado pelo desenvolvimento do conhecimento científico e tecnológico, tende a romper com as antigas estruturas e buscar, como sentido principal, a inovação. Parar neste contexto é sinal de impotência, enquanto a mobilidade passa a ser sinal maior de vitalidade, força e poder.

A mobilidade na qual se vive hoje traz uma particularidade de um tempo passado. Ela não apresenta um objetivo ou um ponto específico de parada. A própria subjetividade não se alimenta mais só de projetos, metas e caminhos bem definidos e norteados na trajetória de vida.

Refletir sobre as condições de vida da atualidade do ser humano que vive numa sociedade urbanizada, altamente sofisticada de relações e, muitas vezes, empobrecida de valores, em um ambiente de mobilidade, é o objeto de estudo deste trabalho. Para sustentar as reflexões aqui suscitadas, a iniciativa foi dialogar com as produções dos autores que tratam das questões em pauta, dentre eles João Batista Libanio, que trata da mobilidade atual; Alfonso Garcia Rubio, que aprofunda o tema do ser humano na Antropologia Teológica e os processos de 
humanização e Joel Portella Amado sobre os processos de evangelização nos ambientes de mobilidade atual.

A atualidade mostra que a sociedade urbana é cada vez mais imediatista, com projetos e episódios de curto prazo e a vida exige uma movimentação constante do ser humano em todos os âmbitos; a flexibilidade e a prontidão para mudar tornaram-se características presentes da humanidade que está em constante movimentação. Esta transitoriedade cria um estado de provisoriedade constante, momentos vividos de forma instável, em que os laços não são de lugar (geográficos), mas são mutáveis e imprevisíveis.

Esta vida urbanizada é uma experiência notoriamente móvel, pois quanto maior e mais heterogênea a cidade, mais as fronteiras se aproximam de raças, nacionalidades, deuses e liturgias diferentes. Neste processo de afluir, as relações humanas não mais possuem um eixo vertical (compreendida assim uma sociedade hierarquizada), porém um eixo horizontal (as posições podem ser trocadas).

A Antropologia Teológica focaliza a pessoa humana em si mesma, na sua relação com Deus, com o outro e com o cosmos. Tudo isso à luz da fé no Deus Salvador, que é, simultaneamente, Criador. Neste tempo de mobilidade, faz-se necessário frisar a visão unitária do ser humano, caso contrário, as relações imediatas e não duradouras ameaçam levar à coisificação do ser humano e a sua desumanização. É na ação de Deus, fundamento que cria, sustenta e torna possível, que o existir humano encontra a sua liberdade e realização. Criado à imagem e à semelhança de Deus, o ser humano é chamado a assumir a sua responsabilidade em relação à história e ao mundo criado. A co-humanidade, aspecto fundamental da visão trinitária na relação com Deus, mune o ser ao diálogo, à decisão e à resposta.

Este estudo não pretende esgotar o tema da mobilidade urbana atual, mesmo porque seria quase impossível, uma vez que a questão da mobilidade do ser humano é presente desde o início da sua história. Também não pretende abordar a mobilidade como realidade de uma cultura específica, tribos e raças humanas em que o nomadismo é um modo de vida, muito menos os que são forçados a moverse pela perda de suas terras ou vivem em regiões de conflitos e são obrigados ao deslocamento. O enfoque se dá à infixidez atual, que aponta para um aspecto singular na identidade social contemporânea, uma humanidade em movimento em 
plena era reconhecida como do neoliberalismo global, em que o mapa mental dos seres humanos é composto segundo a sua permanente circulação.

As transformações ocorridas, nos últimos anos, no âmbito social, político, econômico e religioso, aliadas à hegemonia do neoliberalismo, à força do mercado em todos os espaços globalizados, à flexibilização do trabalho, à substituição da sociedade industrial pela de serviços, têm mudado, profundamente, as relações do ser humano no mundo como, por exemplo, criando "exclusões" para aqueles que não conseguem se adaptar às exigências dessa nova ordem social e econômica. Enquanto os avanços da contemporaneidade, se por um lado contemplam e facilitam a comunicação e o encontro cada vez de forma mais ampla e global, por outro, vive-se numa sociedade com riscos de frustrações sociais, afetivas e religiosas. Estes riscos significam a possibilidade de perder o sentido do tempo histórico e as referências subjetivas, tamanha é a volatilidade e a mobilidade dos acontecimentos nos quais as relações inter-humanas são esquecidas ou deixadas em segundo plano.

A vida é, por definição, movimento; todo ato de movimentar-se ocasiona mudanças. E todo modificar tem, ao mesmo tempo, algo que permanece e algo que se transforma. Em síntese, a transformação envolve a humanidade inteira e, de modo particular, a constituição identitária humana. É claro que não se consegue ver tudo ao mesmo tempo, sob todos os ângulos e aspectos, mas é possível identificar algumas transformações e um fazer diferente, especialmente no que se refere à convivência, pois viver é mais que pensar, mais que querer e sentir.

A realidade é que, enquanto o mundo se torna mais próximo e as populações se aglomeram nos espaços urbanos atuais, os precipícios econômicos, sociais e culturais aumentam rapidamente. Numa tentativa de repensar o conteúdo da fé e da identidade cristã do ser humano nos espaços de mobilidade urbana atual, no primeiro capítulo, o fenômeno da mobilidade será o foco central, o que provoca o caminhar um pouco pela história da humanidade, conceituando urbanização e mobilidade, mostrando que o motor da história se encontra nos processos de movimentação social e que os novos estilos de vida móveis que se formaram nos últimos anos correspondem a um conjunto dos conhecimentos técnicos que a humanidade acumulou durante a sua história. 
Ainda neste primeiro momento, a intenção foi desvendar os desafios de mobilidade enfrentados pela sociedade e traçar o perfil do ser humano que está em constante movimento, especialmente com o advento das novas tecnologias da informação e comunicação que colocaram os homens diante de um contraditório "estar" no mundo. Nunca se esteve no meio de tantos, porém com tantas oportunidades de solidão. Grave também é reconhecer que os bens produzidos pela tecnologia, se por um lado trouxeram importantes benefícios, por outro, não permitiram o usufruto democrático por parte de todos, o que asseverou forte exclusão social em nosso tempo. Diante deste quadro social, torna-se preciso fomentar soluções econômicas, políticas, sociais e religiosas capazes de acompanhar esse ser humano de constante volubilidade, para que ele não perca a sua identidade nesta presente e veloz movimentação do mundo.

Alguns aspectos antropológico-teológicos, acerca do ser humano, como criatura de Deus, pessoa e ser capaz de comunhão, serão abordados no segundo capítulo. As reflexões se fazem a respeito da identidade do ser humano dentro da realidade de mobilidade vivida no mundo contemporâneo, onde esse mesmo ser humano está sempre querendo alcançar e superar seus limites, numa mistura de competição, solidariedade e capacidade de criação. Neste mesmo contexto, ele busca também construir e reconstruir a sua identidade, em condições sempre renovadas diante do perigo iminente e eminente de fragmentação. A pessoa humana, para não se perder nessa realidade de constante movimento, precisa ter consciência de sua identidade e da sua dignidade. Por isso, a necessidade de refletir se a atual mobilidade favorece ou não os processos de humanização.

Por fim, no terceiro capítulo, as reflexões se voltam para o modo como a Igreja Católica Apostólica Romana pode atuar nestes processos de mobilidade urbana atual, através da evangelização, favorecendo assim a construção de valores que humanizam. Para isso, torna-se necessário uma pastoral contextualizada, inserida na realidade humana. A proposta seria traçar um caminho pastoral teológico que vá ao encontro dessa nova conjuntura social.

O presente estudo buscou proporcionar um pensar e um desafio: é possível viver a experiência cristã na mobilidade urbana atual? Em que sentido o urbano atual, marcado pela mobilidade, favorece, ou não, os processos de humanização? Confrontar, analisar e destacar, sempre com uma visão unitária do ser humano, na 
qual se incluem movimentos e estabilidades, são ações que ajudarão a mostrar o ser humano capaz de Deus também nos ambientes de mobilidade, como um ser de caminho. Todas estas indagações possibilitam compreender a importância de uma pastoral encarnada nesta realidade móvel, abrindo novas formas de evangelização que possibilitam o encontro com o Deus de Jesus Cristo, diante do universo da transitoriedade e da itinerância.

A Antropologia Teológica cristã deve ser suporte para ultrapassar lamentações e para buscar iluminar e valorizar os aspectos positivos da mobilidade urbana atual, bem como repensar as propostas pastorais cristãs nos processos de evangelização, a fim de se descobrir como apresentar a mensagem salvífica, neste contexto social e religioso de motilidade em constante transformação. 


\section{1 \\ NOMADISMO URBANO ATUAL}

Com os avanços da tecnologia da informação e comunicação, ocorridos, principalmente, a partir do final do século passado, os espaços urbanos se reconfiguraram, ambientes se ampliaram, em especial onde o acesso à internet e aos produtos da tecnologia. Sem exigir grande movimentação espacial, de sua casa, seu trabalho ou de qualquer lugar, é possível à pessoa comunicar-se, conhecer e interagir com o conhecimento, sem que seja necessário, para isso, o deslocamento físico, processo que interfere, de certa maneira, na vida como um todo. Nesse sentido, pode-se dizer que, em nosso tempo, há uma aceleração e uma transformação no fenômeno urbano, estimulado pelo avanço tecnológico em que a mobilidade das pessoas, movimento de estar no mundo e se relacionar com ele, acontece de maneira diferente daquela que, tradicionalmente, exigia o deslocar-se fisicamente de um lugar para outro, para interagir com novas realidades.

Neste capítulo, buscaremos refletir sobre o nomadismo urbano atual, a partir de uma retomada da história da civilização desde os primeiros povos. Assim, faremos por compreender ser esta retomada uma opção interessante, no intuito de suscitar a análise do sentido de movimento que, próprio do humano, o impulsiona, desde os primórdios de sua existência, a deslocar-se em busca de alcançar seus objetivos, fossem eles de sobrevivência, busca de conhecimento e de progresso ou mesmo da conquista.

O ser humano sempre foi um ser de movimento, e uma das características de alguns povos antigos era o nomadismo. ${ }^{1}$ Em grupos, eles armavam e desarmavam suas tendas, deslocam-se permanentemente, num movimento que era espacial, geográfico. Atualmente, o movimentar-se do ser humano, ganhou outras formas, à medida que foram incorporados, em sua vida social, meios inimagináveis, em épocas passadas, de comunicar-se com o mundo de forma ampla, seja para conhecê-lo, dominá-lo ou simplesmente estar nele em tempo real. Ao longo deste estudo, buscaremos apresentar essas novas formas que proporcionam aos seres humanos movimentar-se e que parecem trazer nova identidade e modos outros de movimento, especialmente dentro dos espaços urbanos.

\footnotetext{
${ }^{1}$ HAROUEL, J. L., História do Urbanismo. Campinas: Papirus, 1990, p.62.
} 
Por certo, não se abandona aqui a mobilidade física, pois também ela foi alcançada pela tecnologia, permitindo que se vá de um ponto a outro do planeta em tempo bastante curto. Preocupa-nos, contudo, como objeto material desta dissertação, a mobilidade como condição de vida, ou seja, não como exceção, mas como regra, a marcar todos os setores da vida humana.

$\mathrm{O}$ aspecto que tentaremos destacar é o da vida urbana. A natureza da cidade é aqui compreendida como lugar ou estrutura física onde são construídas e consolidadas, de forma articulada, as relações políticas, econômicas e sociais. ${ }^{2}$ "Se quisermos lançar novos alicerces para a vida urbana, cumpre-nos compreender a natureza histórica da cidade e distinguir entre suas funções originais aquelas que dela emergiram e aquelas que podem ser ainda invocadas."3

Nosso tempo tem vivenciado, com mais intensidade e complexidade, o fenômeno urbano e da mobilidade. Antes, os povos antigos eram nômades no sentido de migrar fisicamente de um espaço para outro; hoje, a modernidade tecnológica trouxe uma nova realidade de mobilidade, que cumpre investigar. É certo que o ser humano sempre foi um ser de movimento. A diferença consiste em que, antes, o ser humano vivia em constante deslocamento, transportando toda a sua vida consigo. Com a sedentarização, própria da fixação do ser humano à vida das cidades, este processo se inverteu: a vida se tornou voltada para um local, uma geografia e as cidades se tornaram ícones desse processo.

Nos dias de hoje, no entanto, estamos diante de um novo momento na história da humanidade, no qual as cidades se reconfiguram e realizam função importante nos modelos atuais de organização estrutural e cultural de diversos grupos sociais. "A cidade reúne os nômades e no mesmo golpe oferece um novo tipo de nomadismo aos que estão em casa. Há uma recodificação sempre local, atravessada por novos fluxos que se mobilizam."

Estamos numa época histórica em que movimento e estabilidade, nomadismo e sedentarismo se fundem, gerando um novo tipo de sociedade, na qual, novas formas de relações sociais são redesenhadas por um novo tipo de ser

\footnotetext{
${ }^{2}$ GOITIA, F. C., Breve história do urbanismo. Lisboa: Presença, 1992, p.42.

${ }^{3}$ LIBANIO, J. B., As lógicas da cidade: o impacto sobre a fé e sob o impacto da fé. São Paulo: Loyola, 2002, p.16.

${ }^{4}$ CAIAFA, J., Aventuras das cidades: ensaios e etnografias. Rio de Janeiro: FGV, 2007, p.118.
} 
humano. Sobre este novo ser humano de mobilidade atual é que procuramos refletir ao longo de nossa pesquisa.

\section{1}

\section{A Cidade, sua História e uma possível compreensão}

A cidade representa uma grande construção do ser humano, de natureza social. Inicialmente, veremos o processo de formação das cidades, como elas surgiram e como foram importantes para o aparecimento das indústrias, para o desenvolvimento de tecnologias e o processo de urbanização.

O processo de formação das cidades é longo e sua compreensão tem diversas fontes de pesquisa que as definem. ${ }^{5}$ Ao longo da história, as cidades foram chamadas de civilizações, onde ocupações especializadas, o comércio, o estoque de alimentos e o poder foram centralizados.

O crescimento de impérios antigos e medievais favoreceu o surgimento de cidades como Babilônia, Roma, Antioquia, Alexandria e Constantinopla. Este fenômeno aparece, de início, com o surgimento das primeiras vilas neolíticas e áreas urbana na Mesopotâmia, atualmente Iraque; depois, surgiram as do Mediterrâneo e Europa e, finalmente, as cidades na China. As primeiras cidades se constituíram, predominantemente, devido ao desenvolvimento da agricultura, de técnicas para o cultivo e irrigação. Por isso, quase sempre, perto de grandes rios. ${ }^{6}$

Com a criação das cidades, os homens passaram a construir sua vida em função do seu trabalho e da vida da cidade, fixando-se naquele lugar, ou seja, passaram a viver de forma sedentária, circunscritos a determinado território, invertendo dessa forma, o seu primeiro estilo de vida, o nomadismo.

Durante a Idade Média, uma cidade era tanto uma entidade política administrativa como um agrupamento de casas. Morar na cidade passou a ser considerado um ato de liberdade em relação às obrigações rurais, advindas do poder do senhor feudal. "Ao afluir para cidades, os camponeses se libertavam do

\footnotetext{
${ }^{5}$ Entre as obras destacáveis neste campo, podemos indicar: BARROS, José D'Assunção. Cidade e História. Petrópolis: Vozes, 2007; BENEVOLO, Leonardo. História da Cidade, São Paulo: Perspectiva, 1993; GOITIA, Fernando Chueca. Breve história do urbanismo, Lisboa: Presença, 1992; HAROUEL, Jean-Louis. História do Urbanismo. Campinas: Papirus, 1990; MUMFORD, Lewis. A cidade na história: suas origens, transformações e perspectivas. $2^{\mathrm{a}}$ ed. São Paulo: Martins Fontes, 1990.

${ }^{6}$ BENEVOLO, L., História da Cidade. São Paulo: Perspectiva, 1993, p.21.
} 
regime de servidão, não mais se submetendo ao vínculo com a terra e com o senhor que lhes roubavam o trabalho, a comida e o tempo."

No Renascimento, a indústria e a arte também auxiliaram no crescimento de cidades, de modo especial, pela supremacia da economia que advinha das cidadesestado, detentoras de grande concentração de terra e extensivos impérios marítimos. A maioria das cidades do mundo, após a ascensão do feudalismo, era pequena em termos de habitantes, "a agricultura de aldeia cria a concepção monocêntrica. $\mathrm{O}$ espaço se configurava num centro em torno do qual girava a vida

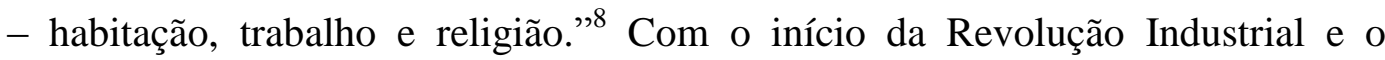
crescimento da indústria no final do século XVIII, surgiram cidades mais populosas. Assim, na medida em que emergiam novas oportunidades geradas pelas cidades, muitos migrantes provenientes de comunidades rurais se dirigiam para áreas urbanas e ali se instalavam. "A grande tarefa do século XX foi a construção das cidades e o fato dominante foi a migração do campo para a cidade." 9

As cidades, na contemporaneidade refletem a complexidade dos tempos atuais sob a égide dos avanços da tecnologia e as profundas transformações que ela promoveu nos modos de produção, decisivos para as mudanças na economia mundial. Podem-se destacar os avanços ocorridos nas áreas da microeletrônica e da teleinformática que aceleraram o processo de globalização e ampliaram as possibilidades da rápida circulação das informações. Desse modo, vai-se da robótica às moedas eletrônicas, de gigantescos bancos de dados a microcomputadores, de celulares a tour por satélite, descobertas que transformaram e transformam profundamente a realidade, ampliando, nesse contexto, o emaranhado de conexões que acontecem no interior das cidades bem como nas suas relações com o mundo. "A cidade é a diversidade de pessoas, ideias, religiões, culturas, modos de viver, profissões, atividades, projetos, partidos, grupos." $" 10$

Vista de longe ou de perto, a cidade seduz pelo fascínio da técnica, do consumo, das vitrines e faz as pessoas sonharem, desejarem e fantasiarem uma

\footnotetext{
${ }^{7}$ ROLNIK, R., O que é cidade. $3^{\text {a }}$ ed. São Paulo: Brasiliense, 1994, p.35.

${ }^{8}$ LIBANIO, J. B., As lógicas da cidade: o impacto sobre a fé e sob o impacto da fé, p. 31 .

${ }^{9}$ COMBLIN, J., Pastoral Urbana: o dinamismo na evangelização. $3^{\mathrm{a}}$ ed. Petrópolis-RJ: Vozes, 2002, p.8.

${ }^{10}$ Ibid., p.10.
} 
felicidade possível. Em muitas situações, o ser humano é exposto a uma pluralidade de valores, de relativismos e de fragmentos.

\section{2}

\section{Sedentarismo, a Vida Urbana Atual e a Mobilidade Social}

O sedentarismo é caracterizado pela mudança do estilo de vida do ser humano, passando do estado nômade ou seminômade para o sedentário, ou seja, pelo fixar-se em determinado território. Dois fatores contribuíram para essa territorialização: a agricultura e a pecuária, que agregaram pessoas, formando vilas, cidades e comunidades. A partir do momento em que o ser humano foi descobrindo que podia plantar e colher seus alimentos, descobriu também que não precisava deslocar-se de uma região para outra em busca da sua sobrevivência. Isso ocasionou uma grande mudança na sociedade, pois permitiu ao ser humano tornar-se sedentário.

Com o advento das indústrias nas cidades, o ser humano deixou o campo e migrou para os centros industriais, na busca de um emprego fixo, de uma mudança de status social, de outras formas de conhecer, de novas tecnologias. O contexto industrial começou a se desenvolver e ganhar força no cenário mundial a partir do surgimento de várias necessidades como a especialização da mão-deobra, a criação de novos setores, novas frentes de trabalho e também, a exigência pela rapidez nos meios de comunicação. De acordo com Kiely,

O industrialismo é associado à emergência da sociedade industrial moderna, que foi a preocupação central dos sociólogos do século XIX. Essa sociedade é baseada num desenvolvimento sem precedentes de novas tecnologias, numa complexa divisão do trabalho, no urbanismo e no potencial surgimento de uma "política de massa." $" 11$

$\mathrm{O}$ industrialismo fez, pois, com que muitas pessoas se deslocassem para o meio urbano, provocando o rápido crescimento industrial. Esse crescimento industrial e a nova sociedade que se formou obrigaram o comércio a acompanhar esse contexto, desenvolvendo-se e gerando novos empregos, pois à medida que a população aumentava, o consumo que já não era mais de produtos artesanais, também teve que aumentar. O comércio ganhou impulso e o desenvolvimento,

\footnotetext{
${ }^{11}$ KIELY, R., Industrialismo. In: SCOTT, J., Sociologia: conceitos-chave. Rio de Janeiro: Zahar, 2010, p. 108 .
} 
com as tecnologias e tornou-se mais acelerado. Esse período fica conhecido como a era tecnológica.

Em decorrência do avanço tecnológico, um elemento marcante nessa nova realidade foi o surgimento da informática, que, de forma galopante, veio interferir na vida das pessoas tanto em relação às ações práticas do cotidiano como nas suas inter-relações pessoais, tecnologias que, por vezes, auxilia nos seus fazeres, por outras, ameaça a sua privacidade.

Cada vez mais o ser humano tem incorporado a tecnologia na sua vida pela praticidade e necessidade de estar todo o tempo online com o mundo. Hoje, é possível ter no bolso praticamente tudo de que precisamos para o trabalho, para a comunicação, para o lazer, para a economia, para o viver.

O ser humano, como já mencionado, por motivos diferentes, desde os tempos antigos, esteve envolto em mudanças e movimentos. As contingências culturais, naturais e da própria sobrevivência, em alguns momentos, determinaram essa mobilidade. É natural do ser humano caminhar, mover-se, conquistar, explorar e conhecer assim como estacionar, fixar-se e criar territórios, também são possibilidades a ele pertinentes. Mover e parar são alternativas, portanto, da condição humana.

A característica marcante do nômade urbano atual é o ir em busca de algo novo, de novas conquista e de novos desafios. A agitação da cidade, a presença das tecnologias e o desenvolvimento fazem com que muitos não se contentem em ficar parados, estagnados na mesma vida. "As pessoas se movimentam por motivos de comércio, estudo, viagens, visitas familiares, para adquirir habilidade ou praticar uma profissão, ganhar dinheiro em moeda forte ou vivenciar uma cultura ou um modo de vida alternativos.",12

Assim, devido a essa revolução tecnológica vivida pela sociedade, os novos modelos de produção, a globalização do comércio, as possibilidades e as necessidades que surgem ou são provocadas, muitos trocaram ou foram obrigados a substituir suas vidas sedentárias por outros estilos de vida, pela agitação de trabalharem a longas distâncias, em cidades ou estados diferentes, ou, ainda, de se transferirem para outros países, sem deixar, inclusive, de se comunicar rapidamente com pessoas, amigos, parentes de sua terra de origem. Como foi

\footnotetext{
${ }^{12}$ COHEN, R., Migração e diásporas. In: SCOTT, J., Sociologia: conceitos-chave, p.124.
} 
cantado por Chico Science: “Um passo à frente e você já não está mais no mesmo lugar."13

Ao falarmos de nomadismo ou sedentarismo, estamos nos referindo às possíveis relações do ser humano com o movimento. Este nos remete à noção de espacialidade. A modernidade e a pós-modernidade cultural mudaram drasticamente a concepção de espaço. O espaço agora é construído pelo ser humano e não mais dado a ele, como no sistema feudal, por exemplo; não é mais um espaço para aceitar e a ele se adaptar. Estamos diante de um espaço a construir, transformar, mudar. O ser humano pós-moderno é errante, transitivo, não está atado a um ponto fixo; caminha para muitas e várias direções. Isso não se dá apenas como movimento espacial e geográfico, uma vez que, além de sair de um ou vários lugares, o ser humano conseguiu mudar sua maneira de viver, sua forma de pensar e de agir. Ele vive hoje um exercício de desenraizamento constante e uma movimentação contínua.

Realidade e condições de uma mobilidade cotidiana permeada de relações, incertezas, descobertas, fragmentações, enriquecimentos culturais e flutuação identitária revelam um estar no mundo inconformado com a perenidade das coisas e das relações. Segundo Valery a "interrupção, incoerência, surpresa são as condições comuns de nossa vida."14 Vivemos, pois, numa era marcada, pela desterritorialização, pela aventura e por uma nova forma de nomadismo, como modo de buscar e conquistar novos horizontes. Essa mobilidade é uma característica marcante da atualidade.

A mobilidade social assume uma importância relevante no exercício pastoral acerca do ser humano na sociedade contemporânea, pois este ser deslocase com bastante intensidade no ambiente social, econômico, geográfico e religioso em busca do progresso e do desenvolvimento. A vida nesta sociedade atual exige, mais do que em outras eras, uma movimentação constante, do aspecto econômico que envolve uma complexa relação com o mercado a todos os outros aspectos da vida humana.

\footnotetext{
${ }^{13}$ SCIENCE, C. (compositor), Afrociberdelia: Um Passeio No Mundo Livre. Chico Science \& Nação Zumbi, 1996.

${ }^{14}$ BAUMAN, Z., Modernidade Líquida. Rio de Janeiro: Zahar, 2001, p.7.
} 


\section{3}

\section{Compreensão de Urbano e Processo de Urbanização}

A primeira observação que se pode fazer a respeito do urbano diz ao fato de que não estamos diante de um conceito unívoco. Utilizado por várias ciências e perspectivas diversificadas, a denominação urbano necessita de indispensável conceituação, todas as vezes que com ela se deseja trabalhar.

$\mathrm{Na}$ maioria das vezes, encontramos identificação no uso das expressões urbano e cidade. Neste caso, trabalha-se com a oposição entre cidade ou urbano versus rural; trata-se de uma concepção espacial de urbano. Estar na cidade consiste, neste caso, estar no mundo urbano. Esta identificação tem suas raízes na origem do termo urbano, ligado à urbe, cidade.

Numa segunda definição, de natureza mais técnica, se identifica urbanização como o conjunto de condições infraestruturais que representam o desenvolvimento das cidades em seu aspecto geográfico, como transportes, água e esgoto, energia elétrica etc. Neste caso, costuma-se dizer que uma região está sendo urbanizada, ou seja, está recebendo a referida infraestrutura. Podemos também nos referir ao urbanismo, termo de uso mais específico, pois referido ao estudo, ao planejamento das cidades e ao "modo de vida de seus habitantes das cidades." 15

Para a reflexão teológica, urbanização possui um sentido específico e não tão diretamente ligado às estruturas físicas de uma cidade. Ela volta sua atenção para as relações humano-sociais que acontecem no interior dessas estruturas, pois o Evangelho, como bem sabemos, destina-se às pessoas. Dito de modo simples, o Reino de Deus consiste num tipo específico de relação com Deus, e também humanas e sociais, relações que podem ocorrer em qualquer estrutura física. Assim, ao falarmos do urbano, para fins desta dissertação, nos referimos às relações que acontecem nas cidades, acompanhando a transformação destas mesmas relações, na medida em que o fenômeno urbano se transforma e as cidades igualmente. Mais que as estruturas físicas que ocorrem nas áreas urbanas, são as relações humanas que se formam nesses ambientes que nós buscamos

\footnotetext{
${ }^{15}$ SCOTT, J., Sociologia: conceitos-chave, p.220.
} 
compreender. "Vivemos [...] diante de uma sociedade pluralista, secularizada e sofrendo rápidas e sucessivas transformações."16

O processo de urbanização das cidades acontece com o desenvolvimento e sua consequente necessidade de estruturar uma determinada comunidade que cresce e se desenvolve, provocando o surgimento de necessidades de planejamentos para que o crescimento possa acontecer de maneira mais organizada e as relações humanas possam ser preservadas. O conceito de urbanização aqui não se limita à concentração de pessoas ou a construção de recurso materiais de infraestrutura, pois com a urbanização também surgem novas relações econômicas, com estilos de vida próprios como o nomadismo urbano, conforme veremos mais adiante.

Crescimento demográfico, industrialização e urbanização fazem parte de um mesmo contexto social. A urbanização não é algo instantâneo que acontece de um dia para o outro. Pode, porém, ocorrer dentro de um processo mais acelerado ou mais lento, dependendo do crescimento populacional e da atividade econômica.

Como vimos, foi com a Revolução Industrial que o processo de urbanização aconteceu nas cidades. As máquinas foram inseridas nesse contexto social, aperfeiçoando os métodos produtivos e determinando o triunfo da indústria capitalista. O processo de urbanização possuiu, porém, uma estrutura diferenciada entre as cidades, cada uma com suas características próprias, sua importância e finalidades. Existiam cidades onde o serviço, o desenvolvimento e a tecnologia atuavam a todo vapor e em outras nem tanto. O grau de urbanização foi diferente, pois, em cada cidade, porém, em todas, ele estava presente.

Segundo Bauman, "Nem toda a vida urbana é moderna, mas toda vida moderna é urbana. Tornar-se moderno significa, no que se refere à vida, assemelhar-se mais à vida urbana." $" 17$ As cidades mais desenvolvidas e de maior importância na economia foram destacando-se e agregando cidades vizinhas, surgindo, assim, as metrópoles. No dizer de Santos "o perfil urbano se torna complexo, com tendência à onipresença da metrópole, através de múltiplos fluxos de matérias e são o novo arcabouço dos sistemas urbanos." ${ }^{18}$

\footnotetext{
${ }^{16}$ MIRANDA, M. F., Igreja e Sociedade. São Paulo: Paulinas, 2009, p.6.

17 BAUMAN, Z., A vida fragmentada: ensaios sobre a moral pós-moderna. Lisboa: Relógio D’água, 2007, p.133.

${ }^{18}$ SANTOS, M., A Urbanização Brasileira. São Paulo: Hucitec, 1993, p.10.
} 
Podemos dizer que hoje, as mudanças sociais e as transformações do próprio ser humano originam-se essencialmente das transformações tecnológicas. Com essas transformações, chegamos ao projeto genoma, às telecomunicações e as grandes redes sociais virtuais. Por conseguinte, tais fatos forçaram o ser humano a mudar o seu próprio estilo de vida, sua mentalidade, conceitos e formas de conhecimento.

A urbanização nas cidades acontece mais rápido que no campo, porque é na cidade que o povo se aglomera. ${ }^{19}$ É na cidade que surgem os conflitos e a necessidade de procurar respostas, soluções e possibilidades para as realidades emergentes. Isso não significa que no campo essa realidade não exista como afirmou Vianna:

[...] O urbanismo é condição moderníssima da nossa evolução social. Toda a nossa história é a história de um povo agrícola, é a história de uma sociedade de lavradores e pastores. É no campo que se forma a nossa raça e se elaboram as forças íntimas de nossa civilização. O dinamismo da nossa história, no período colonial, vem do campo. Do campo, as fases em que se assenta a estabilidade admirável da nossa sociedade no período imperial. ${ }^{20}$

O mundo atual tem presenciado uma nova fase da urbanização, com uma procura maior por trabalhadores intelectuais, como os consultores econômicos, os planejadores, os administradores, etc. Inclusive, a própria indústria agrícola, localizada em áreas rurais, tem exigido uma tecnologia de ponta, com necessidade da presença desses trabalhadores qualificados.

Com esse quadro, aquela ideia de que rural significa ultrapassado, ficou para trás, fazendo com que haja uma maior integração entre o campo e a cidade. A urbanização acontece de maneira unívoca nos dois cenários, de maneira que não se pode mais ligar urbanização apenas à cidade, ela acontece no cenário global. Como afirmou Santos:

A cidade dos notáveis, onde as personalidades notáveis eram o padre, o tabelião, a professora primária, o juiz, o promotor, o telegrafista, cede lugar à cidade econômica, onde são imprescindíveis o agrônomo (que antes vivia nas capitais), o veterinário, o bancário, o piloto agrícola, o especialista em adubos, o responsável pelos comércios especializados. ${ }^{21}$

A urbanização foi se desenvolvendo cada vez mais depressa no campo, porque os agricultores passaram a residir nas cidades centrais, buscando informação e tecnologia para levarem ao campo.

\footnotetext{
${ }^{19}$ BARROS, J. A., Cidade e História. Petrópolis: Vozes, 2007, p.105.

${ }^{20}$ VIANNA, O., Evolução do Povo Brasileiro. $4^{\mathrm{a}}$ ed. Rio de Janeiro: José Olympio, 1956, p.53.

${ }^{21}$ SANTOS, M., A Urbanização Brasileira, p.56.
} 
O que acontece hoje é um intercâmbio cultural, econômico e científico entre os diversos tipos de áreas econômicas, tanto a agrária como a industrial. Um consome aspectos importantes do outro, um influencia o outro. A produção rural absorve inovações tecnológicas e científicas produzidas nas cidades. Nesse contexto, é urgente pensar em uma sociedade que acompanhe esse desenvolvimento, adaptando-se as novas técnicas. Não basta apenas uma parcela da sociedade fazer essas adaptações e estar conectada com todo o mundo; é preciso inserir esse novo estilo de vida em todo quadro social, pois, caso contrário, ter-se-ia uma sociedade com traços de desigualdades absurdas não apenas social, mas também tecnológica, criando mundos completamente opostos. Essas desigualdades sociais e tecnológicas, infelizmente, ainda estão presentes em nossos dias, e uma parece incidir, na maioria dos casos, sobre a outra; é possível encontrar uns com "conectividade" planetária, outros sem o conhecimento para ligar um computador.

Cada vez mais, nos tempos atuais, uma diversidade de opções econômicas, de realidades, de lazer e de empregos se apresenta. A cidade com sua produtividade, com a força da tecnologia desenvolvida em seu meio, tornou-se globalizada e integrada com os principais mercados nacionais e internacionais. Segundo Sklair,

A globalização genérica pode ser definida por quatro fenômenos que emergiram ou se intensificaram desde meados do século $\mathrm{XX}$ : a) a revolução eletrônica, que transformou a base tecnológica e o escopo global dos meios de comunicação de massa e grande parte da infraestrutura material do mundo atual; b) a descolonização da maior parte da África, Ásia e Caribe, com impactos importantes sobre as atividades econômicas e culturais transfronteiriças e sobre as formas de migração e pós-colonialismo; c) a criação de espaços sociais transnacionais; e d) formas qualitativamente novas de cosmopolitismo, que permitem que pessoas e grupos construam múltiplas identidades. ${ }^{22}$

Além dos avanços ocorridos com o desenvolvimento das tecnologias da informação e comunicação, as evoluções no transporte terrestre, marítimo e aéreo fizeram com que as distâncias se aproximassem, fazendo com que as produções se difundissem por todo o mundo. Diante de tais realidades, registra-se uma ruptura com a hierarquia urbana tradicional e uma nova forma de modelo de relações se reconfigura, com uma maior complexidade com "uma urbanização concentrada, com a multiplicação de cidades de tamanho intermediário, para alcançarmos,

\footnotetext{
${ }^{22}$ SKLAIR, L., Globalização. In: SCOTT, J., Sociologia: conceitos-chave, p.94 et. seq.
} 
depois, o estágio da metropolização, com o aumento considerável do número de cidades milionárias e de grandes cidades médias." 23

Aquele tempo em que a sociedade era homogênea, com proletariado, campesinato e burguesia, ficou no passado. A sociedade de hoje é construída por um tecido complexo e com atores bem diferentes daquela outra sociedade. Vivese agora em "sociedades" urbanizadas. Uma frase de um relatório das Nações Unidas retrata bem esse contexto: "o Estado-nação tornou-se pequeno demais para as grandes cidades, e grande demais para as pequenas." 24

O mundo moderno está sendo despertado, cada vez mais, para novas iniciativas de organização social provocadas pelo mundo digital. Nunca, na história da humanidade, a informação esteve tão ao alcance de quase todos. Inúmeras coisas a nossa volta parecem estar abertas à mudança. ${ }^{25}$ As sociedades contemporâneas caracterizam-se por fragmentação crescente da experiência dos atores sociais, dissociação entre mundo da racionalidade instrumental e o mundo simbólico e cultural, entre tecnologia e valores, entre mundo objetivo e subjetivo, que atravessa a vida individual e a situação mundial. Ainda conforme coloca Touraine:

Não encontramos mais a terra firme de uma ordem social construída sobre instituições sólidas e métodos firmes de socialização. Vivemos uma mudança permanente que dissolve as instituições como se fossem bancos de areia, que confunde as balizas sociais, as normas e o que se chamavam os valores da comunidade. $\mathrm{O}$ nadador não tem outra saída senão construir uma balsa $\mathrm{e}$ sobreviver. ${ }^{26}$

Não restam dúvidas de que a informação mundial invadiu a casa de cada ser humano, que os conflitos sociais, as disputas políticas, as catástrofes que acontecem em qualquer lugar do mundo influenciam a vida de cada indivíduo em todos os lugares do planeta. Tudo está interligado, a sociedade não se restringe a uma cidade, ou a um estado.

Na era moderna, o nível de distanciamento tempo-espaço é muito maior do que em qualquer período precedente, e as relações entre formas sociais e eventos locais e distantes se tornam correspondentemente "alongadas". A globalização se refere essencialmente a este processo de alongamento, na medida em que as modalidades de conexão entre diferentes regiões ou contextos sociais se enredaram através da

\footnotetext{
${ }^{23}$ SANTOS, M., A Urbanização Brasileira, p.77.

${ }^{24}$ DOWBOR, L., A reprodução social. vol. I, Petrópolis: Vozes, 2011, p.35.

${ }^{25}$ DOMINGUES, J. M., Interpretando a modernidade: imaginário e instituições. Rio de Janeiro: FGV, 2002, p.17.

${ }^{26}$ TOURAINNE, A., Poderemos Viver Juntos? Iguais e Diferentes. São Paulo: Instituto Piaget, 1998, p.62.
} 
superfície da Terra como um todo. A modernidade é inerentemente globalizante. [...] A globalização pode assim ser definida como a intensificação das relações sociais em escala mundial, que ligam localidades distantes de tal maneira que acontecimentos locais são modelados por eventos ocorrendo a muitas milhas de distância e vice-versa. ${ }^{27}$

Como dito, a urbanização acontece quando algo se torna urbano, organizado, com técnicas e construções. Sendo assim, diante desse cenário, novas formas de se relacionar, novos pensamentos, novos estilos de vidas também são criados. Vimos também que a urbanização acontece tanto na área agrícola como na industrial, o que a difere é o grau de urbanização que encontramos na cidade ou no campo. Assim, urbano, urbanização e urbanismo têm a mesma raiz e natureza, porém funções diferentes. O que quisemos salientar e deixar claro é que todas essas ideias nos conduzem a uma mudança, e a mudança que nos interessa são as novas formas de relações humanas que delas surgem.

\section{4 Compreensão de Nomadismo Urbano}

São recorrentes, na história humana, a errância e a busca pelo novo, subjacentes ao nomadismo, mobilidade e estabilidade, realidades sociais. O nomadismo, se por um lado remete à migração de um lugar para o outro, leva também à formação de identidade. O êxodo bíblico é um bom exemplo desse processo da constituição da identidade de um povo. Ao atravessar o deserto de Sur e, posteriormente, o do Sinai, o povo Hebreu se constituiu como um grupo coeso e com uma identidade étnica e cultural comum.

A palavra nômade já foi usada para expressar o individuo que leva uma vida errante. Hoje, apesar de ainda ser utilizada nesse sentido, também encontramos a palavra nômade sendo utilizada para identificar aqueles que vivem mudando de lugar por necessidades econômicas, empresariais e políticas, sem uma habitação fixa. Nesta dissertação, procuramos mostrar o surgimento, nos contextos urbanos atuais, de uma terceira noção de nomadismo, em que as pessoas, mesmo tendo habitações fixas, estabelecem relações vitais marcadas pela mobilidade. Para este propósito, revisitaremos aspectos históricos do percurso da humanidade.

O ser humano pré-histórico vivia à procura de água e comida, pois não sabia ainda cultivar seu próprio alimento. A agricultura ainda não havia sido descoberta.

\footnotetext{
${ }^{27}$ GIDDENS, A., As consequências da modernidade. São Paulo: UNESP, 1991, p.69.
} 
Esse período é conhecido como o período paleolítico, dos caçadores nômades. Sempre em grupos, esses seres humanos fixavam-se em um lugar onde pudessem caçar e colher frutos e vegetais. Quando esses alimentos ficavam escassos, levantavam acampamento e procuravam outro lugar com as mesmas características. O nomadismo era uma prática cultural e não se conhecia outro estilo de vida. Assim ressaltou Cohen: "As pessoas se moviam em bandos defensivos em busca de comida e em resposta a mudanças climáticas"28, acrescentando que esse movimento "foi responsável pela construção social de comunidades. ${ }^{29}$

Os seres humanos que viviam no período Paleolítico da caça, da pesca e dos frutos que a terra fornecia, eram nômades. As suas habitações não eram fixas. Apesar de algumas pessoas acreditarem que foi com a descoberta da agricultura que o homem resolveu fixar a sua moradia.

Mumford explica que a fixação permanente das sociedades simples não teve correlação somente com a semeadura e a sazonalidade, mas com um tipo de questão totalmente diferente. De acordo com o autor, a morte das pessoas anciãs representava, para o saber mítico, o problema mais fascinante, como se nele se pudesse entrever o significado mais íntimo e oculto da existência. ${ }^{30}$

Constata-se que, ao longo da história, a busca dos povos antigos por alimentos exigia deles uma mudança contínua, uma mobilidade à procura desses recursos quando se faziam escassos. Terra, comida e clima tornaram-se fatores determinantes de deslocamento, de mobilidade.

Os nômades, ao longo da história, foram conhecidos não pelo que carregavam, mas principalmente pelo que deixavam para trás, por confiarem na natureza que lhe daria o sustento necessário. Os Beduínos, por exemplo, povos nômades do deserto do Saara, não carregavam água por terem o conhecimento de onde se encontravam os oásis.

Com o passar dos anos, este povo nômade, que não se prendia muito às normas territoriais, vivia sem muitas preocupações e desrespeitava as regras das fronteiras, passou a ser tratado como verdadeiro "vilão" do progresso. Por isso é

\footnotetext{
${ }^{28}$ COHEN, R., Migração e diásporas. In: SCOTT, J. Sociologia: conceitos-chave, p.123.

${ }^{29}$ Ibid., p.124.

${ }^{30}$ MUMFORD, L., A cidade na história: suas origens, transformações e perspectivas. $2^{\mathrm{a}}$ ed. São Paulo: Martins Fontes, 1990, p.21.
} 
que os nômades foram muito discriminados no início da era moderna e seus hábitos mal vistos. Bauman nos lembrou recentemente

[...] de que o advento da era moderna significou, entre outras coisas, o ataque consistente e sistemático dos 'assentados', convertidos ao modo sedentário de vida, contra povos e estilos de vida nômades, completamente alheios às preocupações territoriais e de fronteiras do emergente Estado moderno. Khaldoun, no século XIV, podia elogiar o nomadismo, que faz com os nômades "sejam melhores que os povos assentados porque [...] estão mais afastados de todos os maus hábitos que infectaram o coração dos assentados. ${ }^{, 31}$

Estamos vivendo um novo tipo de nomadismo na sociedade contemporânea, que tem suas raízes na tecnologia, do desenvolvimento e da globalização.

[...], vive-se hoje uma era pós-moderna, onde o nomadismo está se destacando novamente, vencendo preconceitos, derrubando barreiras construídas pelos próprios homens da modernidade, pois chegou-se a uma época em que não se pode mais falar de modernidade, de avanços tecnológicos e científicos, sem se render ao nomadismo. Avanços cada vez mais rápidos exigem deslocamentos cada vez mais velozes. Nesse período de fluidez vivido pela sociedade, a vida nômade atropela a vida sedentária. "Numa notável reversão da tradição milenar, são os grandes e poderosos que evitam o durável e desejam o transitório."32

O nomadismo além de suscitar uma ideia de movimento, migração e deslocamento, também remete o ser humano a um questionamento sobre a vida, o cotidiano, a rotina, levando-o a uma reflexão a respeito de sua identidade. A mobilidade dos tempos atuais é muito mais abrangente do que o nomadismo vivido outrora, com um deslocamento apenas físico, de territórios. Também vai de encontro aquele poder de submissão que os senhores feudais e a nobreza exerciam sobre os vassalos e os mais pobres, que os deixavam sem liberdade de movimento, quanto à questão social e territorial. "O domínio do tempo era o segredo do poder dos administradores e imobilizar os subordinados no espaço, negando-lhes o direito ao movimento, era a principal estratégia em seu exercício do poder."33

Hoje, não se movimenta apenas em busca de alimentos, por terras ou água. $\mathrm{Na}$ verdade, o nomadismo pode ser tudo isso, tendo como principal característica a liberdade, seja a cultural, a intelectual ou a religiosa. As pessoas já não aceitam mais qualquer explicação, pois a informação, a cultura e o conhecimento estão disponíveis de uma forma que jamais tiveram, dependendo, por muitas vezes,

\footnotetext{
${ }^{31}$ BAUMAN, Z., Modernidade Líquida, p.19.

${ }^{32}$ Ibid., p. 21.

${ }^{33}$ Ibid., p. 17 .
} 
apenas de um "click". Contudo, essa liberdade de movimento traz ao ser humano moderno a fluidez de identidades e o conflito nas relações. Nos dias atuais, o nomadismo pode ter alguma relação com a mudança das pessoas de cidades, estados e país, mas tem muito mais com as mudanças comportamentais, ideológicas e culturais, de rapidez e de ideias.

o advento do telefone celular serve bem como 'golpe de misericórdia' simbólico na dependência em relação ao espaço: o próprio acesso a um ponto telefônico não é mais necessário para que uma ordem seja dada e cumprida. Não importa mais onde está quem dá a ordem - a diferença entre 'próximo' e 'distante', ou entre o espaço selvagem e o civilizado e ordenado, está a ponto de desaparecer. ${ }^{34}$

O nomadismo pode ter várias faces, fases ou interesses, mas ele tem sempre um mesmo ideal ou uma mesma finalidade: a liberdade de buscar sonhos e conquistas.

No sentido de alcançar o seu aperfeiçoamento como ser, o indivíduo tem a possibilidade de, numa mesma sociedade, inserir-se em diferentes espaços sociais, onde ele se desenvolverá a partir das especificidades e função que cada um desses lugares suscita. Em relação ao trabalho, por exemplo, cada profissão se constitui em meio próprio e particular de organização a partir de conjunto de ideias construídas com base em costumes, práticas, percepções da realidade, aptidões, valores e conhecimentos específicos, que, quando internalizada pelo jovem, contribui sobremaneira para seu preparo e amadurecimento para a realização de determinada função essencial e a sua integração produtiva na sociedade.

Assim, a mobilidade e o movimento fazem parte da vida do ser humano, das suas raízes e origens. Se por um lado, hoje, muitos seres humanos fixam sua moradia em algum lugar determinado, por outro, e ao mesmo tempo, eles se movem muito mais rápido, sendo capazes, por exemplo, de se comunicarem com várias pessoas simultaneamente, inclusive em países diferentes através da internet. É um deslocar-se que pode ser tanto de maneira territorial como de modo virtual.

A mobilidade hoje, portanto, é uma forma de nomadismo não mais só histórico, cultural ou forçado, mas urbano, que se constitui de relações humanas vividas cada vez mais em episódios de curto e médio prazo. As intensificações das relações sociais, em escala mundial, em que acontecimentos são marcados por eventos distantes do próprio local, derrubando fronteiras, interligando pessoas,

\footnotetext{
${ }^{34}$ BAUMAN, Z., Modernidade Líquida, p.18.
} 
encolhendo distâncias e acelerando movimentos, traduzem o que se constitui a mobilidade urbana atual.

Deste modo, os estilos de vida de muitos seres humanos urbanos atuais assemelham-se aos dos povos nômades de outrora. Mesmo entre os mais sedentários, a mobilidade tornou-se necessária e constante. Como exemplo, podese citar a vida do atleta profissional que, em cada época, está em um lugar, em um estado ou país diferente; outro exemplo é a vida dos grandes empresários que administram seus negócios em, pelo menos, dois estados diferentes, vivendo cada tempo em um estado e realizando viagens sucessivas de negócios. Também se pode destacar a vida do estudante que sai do interior para estudar na capital ou em outro país, assim como a do trabalhador da construção civil, que fixa a sua morada na cidade onde a obra de uma construção civil está acontecendo e, quando acaba a obra, reconhece é o momento de "levantar acampamento" e ir em busca de nova construção e de novo emprego em outra cidade. Também existe a realidade daqueles trabalhadores que, muitas vezes, deixam o campo, a agricultura, para buscar na cidade uma qualidade de vida melhor para si e para a sua família.

Por fim, destaca-se a vida de muitos ciganos que podem ser encontrados nas cidades e vivem o nomadismo de maneira bem intensa, quase que no sentido original dos primeiros povos nômades. "É importante saber que os ciganos são nômades, mas nem todos os nômades são ciganos. Existem povos na África, América, Ásia e norte da Europa que migram conforme os ritmos do pastoreio, da caça ou da pesca." ${ }^{, 35}$

Sedentarismo e nomadismo são duas formas possíveis de vivência. No entanto, as contingências da mobilidade, que afetaram o ser humano em outras épocas e o levaram ao nomadismo, são diferentes das movimentações que ocorrem na atualidade. $\mathrm{O}$ advento da modernidade representou um forte impulso na movimentação do ser humano contemporâneo.

É quase uma condição sine qua non movimentar-se. Ficar parado ou estacionar, no contexto globalizado, significa impotência, enquanto a mobilidade é sinal de vitalidade, força e poder. O ser humano de hoje não mais só se define apenas migrante ou viajante. Ele está envolvido no fenômeno da mobilidade atual.

\footnotetext{
${ }^{35}$ GASPARET, M., O rosto de Deus na cultura milenar dos ciganos. São Paulo: Paulinas, 1999, p.24 et. seq.
} 
A sociedade urbana contemporânea é cada vez mais uma rede ${ }^{36}$, com uma série de projetos e episódios de curto prazo. A mobilidade tem gerado um estado de provisoriedade permanente e um exemplo marcante desta provisoriedade são as relações humanas. Os laços não só são de lugar, geográficos; são mutáveis e imprevisíveis. A vida urbana hoje é uma experiência notoriamente nômade, quanto maior e mais heterogênea a cidade mais as fronteiras se aproximam de raças, nacionalidades, deuses e liturgias diferentes.

"Hoje em dia estamos todos em movimento.",37 A mobilidade torna-se um marco da vida nas grandes cidades, sendo um deslocamento das relações entre tempo e espaço, causado pela inquietude contemporânea fazendo surgir novos espaços. O nomadismo atual é decorrente das transformações socioculturais. A realidade social no ambiente urbano, provocadora de um deslocamento constante, ao gerar uma mobilidade que arrasta as pessoas, muitas vezes, de uma cidade para outra, de um país para o outro, possibilita também a construção de espaços e relações com outros grupos de diferentes culturas, facilitando um vasto enriquecimento cultural.

O que mais nos chama a atenção nos tempos atuais é o nomadismo virtual, que permite a comunicação entre pessoas de diversas partes do mundo, criando assim uma constante troca de informações. É a tecnologia moderna, capaz de mover pessoas de uma realidade a outra em questão de segundos.

O ser humano urbano atual, diante dos recursos que a tecnologia oferece, passou a se assemelhar aos antigos nômades, que só carregavam o necessário, uma vez que não mais precisam carregar papéis, livros, documentos e outros tantos recursos. Hoje, é possível sair de casa apenas com um pequeno aparelho eletrônico e ter acesso a tudo isso, pois tudo o que é preciso está ao alcance das mãos. Nesse universo globalizado em que se encontra o ser humano, torna-se necessário perceber quais valores ele vai adquirindo ou perdendo na construção de sua identidade.

[...] o 'pertencimento' e a 'identidade' não têm a solidez de uma rocha, não são garantidos para toda a vida, são bastante negociáveis e revogáveis, e de que as decisões que o próprio indivíduo toma, os caminhos que percorrem, a maneira

\footnotetext{
${ }^{36}$ PERGOLA, G. D., Viver a cidade: orientações sobre problemas urbanos. São Paulo: Paulinas, 2000, p. 27.

${ }^{37}$ ALMEIDA, M. I. M. \& TRACY, K. M. A., Noites nômades: espaço e subjetividade nas culturas jovens contemporâneas. Rio de Janeiro: Rocco, 2003, p.17.
} 
como age [...] são fatores cruciais tanto para o 'pertencimento' quanto para a 'identidade'. ${ }^{38}$

A conectividade e a modernidade eletrônica abrem novos horizontes de articulação social, favorecendo maior desenvolvimento e um conhecimento compartilhado. Esse avanço do conhecimento está acontecendo de modo acelerado.

Transportes, telecomunicações, energia e água têm em comum o fato de constituírem uma rede que permite que a vida esteja interligada como um conjunto. Os transportes, por exemplo, constituem-se em importante forma de mobilidade social e essencial para a economia. A aviação é utilizada não mais como apenas um transporte para passeio, mas como um transporte importantíssimo para o trabalho.

Entretanto, o avanço das telecomunicações, que permitiu a realidade do mundo digital, tornou fato esse transporte por meio de fibras óticas. É possível discutir assuntos financeiros, econômicos e trabalhistas, com várias pessoas de diferentes países, "sozinho" e, sem sair de casa. Essa tecnologia globalizada é responsável pela transformação do planeta. $\mathrm{Na}$ medida em que os sistemas de comunicação facilitam a vida dos grandes autores econômicos a se articularem de uma forma instantânea, também facilita o dia a dia de uma dona de casa, que pode, por exemplo, comparar preços de determinados produtos sem sair de casa e em diversas lojas do país. "[...] O mundo da supermodernidade não tem as dimensões exatas daquele no qual pensamos viver, pois vivemos num mundo que ainda não aprendemos a olhar."

Em síntese, o nomadismo traz consigo sentidos para o movimento e, como tal, é próprio do ser humano viver em constante busca. No entanto, o nomadismo atual apresenta características diferentes daquele que caracterizou os povos primitivos ou mesmo os ciganos. Os primeiros povos nômades não tinham a dimensão do espaço a ser explorado dado o desconhecimento e a pouca apreensão que este poderia propiciar, de modo a permitir a real dimensão do mundo natural e humano. Seguiam movidos pela esperança e pela necessidade de sobrevivência;

\footnotetext{
${ }^{38}$ BAUMAN, Z., Identidade. Rio de Janeiro: Jorge Zahar, 2005, p.17.

${ }^{39}$ AUGÉ, M., Não lugares: introdução a uma antropologia da supermodernidade. São Paulo: Papirus, 1994, p.37.
} 
eram "caçadores". Sua percepção do mundo se construía a partir do que conheciam pela vivência.

O nômade urbano dos dias de hoje percorre espaços ilimitados, por vias outras conquistadas pela própria ação do ser humano nas suas descobertas e inovações, produto dos achados científicos. A movimentação física cedeu lugar à movimentação produzida por capacidades mentais complexas. Nesse movimento, ele pode seguir fisicamente só, porém se relacionando globalmente com o mundo, expandindo e coordenando amplas redes de diálogos e de novas descobertas. É um estar no mundo em constante busca, não mais pelo alimento físico num movimento de caça, mas numa teia que se reconfigura em velocidade inimaginável envolvendo profundas mudanças no ser e no estar no mundo.

Em outras palavras, a modernidade é a impossibilidade de permanecer fixo. Ser moderno significa estar em movimento. Não se ressalve estar em movimento como não se resolve ser moderno... Nesse mundo, todos os habitantes são nômades, mas nômades que perambulam a fim de se fixar. Além da curva, existe, deve existir, tem de existir uma terra hospitaleira em que se fixar, mas depois de cada curva surgem novas curvas, com novas frustrações e novas esperanças ainda não destroçadas. ${ }^{40}$

\section{5 \\ Perfil do Ser Humano Nômade Urbano}

A globalização é uma realidade irreversível e um processo que afeta a todos. Esse processo que vivenciamos em nossa atualidade promove a universalidade e a uniformidade global dos seres humanos. Ele tanto divide como une. Para alguns é sinal de liberdade e para outros é um destino indesejado e cruel. A globalização, segundo Brumer, “[...] se caracteriza atualmente por uma integração entre todos os países da terra e entre regiões de um mesmo país - incluindo suas populações - em termos econômicos, políticos, sociais e culturais." 41

Entendemos cultura em sentido antropológico (GS, n. 53), como o conjunto de sentidos, valores e padrões assumidos e vividos por um grupo social concreto como expressão de sua própria realidade humana. É a cultura que faz do indivíduo um ser humano. Através dela ele se conhece como tal e entende a realidade que o circunda, organiza a vida social e profissional, goza de uma linguagem para se expressar e de um ethos para agir. A cultura se encontra não só nas representações, mas ainda, e principalmente, nas próprias ações de um grupo social. ${ }^{42}$

\footnotetext{
${ }^{40}$ BAUMAN, Z., O mal-estar na pós-modernidade. Rio de Janeiro: Zahar, 1998, p.92.

${ }^{41}$ BRUMER, A., Gênero, família e globalização. Porto Alegre: Sociologias, n. 21, jun. 2009. Disponível em <http://www.scielo.br/scielo.php?script=sci_arttext\&pid=S1517-452220090001000 02\&lng=pt\&nrm=iso $>$. Acesso em 01 out. 2012. http://dx.doi.org/10.1590/S1517-45222009000 100002 .

${ }^{42}$ MIRANDA, M. F., Igreja e Sociedade. São Paulo: Paulinas, 2009, p.14.
} 
Dentro de uma sociedade global e de veloz mobilidade em todos os níveis sociais, políticos, culturais, afetivos e religiosos, colocar a questão da identidade e humanização como elemento fundamental no eixo antropológico é de extrema importância. "Estar em movimento não é mais uma escolha. Agora se tornou um requisito indispensável.",43

As definições de espaços se ampliaram, hoje, além dos espaços territoriais, também existem os virtuais. Ao mesmo tempo em que o ser humano se afasta do contato com seus vizinhos de bairro, relaciona-se com desconhecidos virtuais, que podem estar tão longe fisicamente.

Em vez da união, o evitamento e a separação tornaram-se as principais estratégias de sobrevivência nas megalópoles contemporâneas. Não há mais a questão de amar ou odiar o seu vizinho. Manter os vizinhos ao alcance da mão resolve o dilema e torna a opção desnecessária; isso afasta situações em que a opção entre o amor e o ódio se faz necessária. ${ }^{44}$

Uma das conquistas fundamentais da nova realidade global de movimentos é que esta, cada vez mais, reúne questões sociais em ações coletivas.

As imagens de desumanidade que dominam as terras onde vivem possíveis migrantes vêm, portanto, a calhar. Elas reforçam a determinação que não dispõe de argumentos éticos e racionais a apoiá-la. Ajudam os habitantes locais a permanecerem locais, ao mesmo tempo que permitem aos globais viajar com a consciência limpa. ${ }^{45}$

Virtualmente, mudamos de lugar, de casa ou viajamos entre locais onde não residimos. Sem precisar nos deslocar, a tela do computador nos leva aonde quisermos ir, num permanente movimento. No mundo em que habitamos, a distância não parece importar muito, não há mais tantas fronteiras naturais. Onde quer que estejamos em determinado momento, não podemos evitar saber que poderíamos estar em outro lugar. Há cada vez menos razão para ficarmos em algum lugar. "De fato vivemos num estranho círculo cujo centro está em toda parte." $" 46$

A imobilidade não existe mais como opção num mundo que, em sua essência, busca a mutação e o movimento; não faz, pois, sentido violentar a natureza humana que é de permanente movimento, e a expressão nomadidade

\footnotetext{
${ }^{43}$ BAUMAN, Z., Identidade, p.46.

${ }^{44}$ Id., Globalização: as consequências humanas. Rio de Janeiro: Jorge Zahar, 1999, p.56.

${ }^{45}$ Ibid., p.84.

${ }^{46}$ Ibid., p. 85 .
} 
ganha novo viés e nova característica, uma delas é ir sem perder as raízes do lugar, ou seja, é não deixar para trás, como era a prática dos primeiros povos nômades, mas reestruturar, reinventar e reprocessar informações e saberes em novos e dinâmicos conhecimentos.

A existência atual estende-se ao longo da hierarquia do global e do local, com a liberdade global de movimentos indicando promoção social, progresso e sucesso, e a imobilidade exalando o odor repugnante da derrota, da vida fracassada e do atraso. "A imobilização é o destino que as pessoas perseguidas pelo medo da própria imobilização desejam naturalmente e exigem para aqueles que elas temem e consideram merecedores de uma dura e cruel punição.”,47

As ambições da vida são comumente expressas em termos de mobilidade, da livre escolha de lugar, da viagem, de ver o mundo; os medos da vida, ao contrário, são expressos no confinamento, na falta de mudança, no impedimento de acesso a locais que os outros facilmente frequentam, exploram e desfrutam. A "boa vida" é a vida em movimento, mais precisamente o conforto de ter confiança na facilidade com que é possível mover-se caso ficar não mais satisfaça. Liberdade veio a significar acima de tudo liberdade de opção, e a opção adquiriu notoriamente uma dimensão espacial. $^{48}$

O distanciamento do ser humano de realidades que favoreçam o diálogo, o convívio com outras pessoas e do exercício da ética pode resultar numa aproximação comprometedora das realidades transgressoras, do predomínio dos bens materiais, do ter e do prazer, desenvolvendo individualismo e egocentrismo.

Se os indivíduos alterdirigidos viessem a descobrir quanto trabalho inútil eles fazem, a descobrir que seus próprios pensamentos e suas próprias vidas valem tanto quanto o pensamento e a vida dos outros, e que, na verdade, não lhe é dado mitigar sua solidão dentro de uma multidão de pares, mais do que se pode mitigar a sede bebendo água do mar, estão poderíamos esperar que eles se tornassem atentos a seus próprios sentimentos e aspirações. ${ }^{49}$

A indiferença e o anonimato seduzem, pois toleram a singularidade. Esse espaço encontrado na cidade seria o espaço da tolerância do diferente. O perigo está na construção de relações somente funcionais, esvaziando o valor das relações primárias.

Relação pessoal ou familiar, cordialidade e acolhimento, são condições humanas essenciais a nossa existência, que são sufocadas pelo frenético circular que o mundo pós-moderno impõe ao humano. O relacionamento com os outros é

\footnotetext{
${ }^{47}$ BAUMAN, Z., Globalização: as consequências humanas, p.130.

${ }^{48}$ Ibid., p.129.

${ }^{49}$ RIESMAN, D. \& GLAZER N. \& DENNEY, R., A multidão solitária: um estudo de mudanças do caráter americano. São Paulo: Perspectiva, 1971, p.378.
} 
fatigado pela nova configuração dos espaços urbanos. As artérias desse campo urbano, que são as cidades, com suas ruas que cortam construções e ligam saídas, de uma cidade a outra, e estradas, não visam a um contato entre as pessoas, mas ao fluir dos veículos.

Hoje, o volume de veículos urbanos trafegando pelas ruas tem gerado um problema crônico na mobilidade; aos enormes engarrafamentos, somam-se o stress e a intolerância. A cidade moderna atual se caracteriza pelo fluxo móvel de pessoas, de bens, veículos e de multidões, surgindo o anonimato urbano. "Nas cidades nos confrontamos constantemente com estranhos. A rua reúne desconhecidos, mesmo que fugazmente ou provisoriamente, e mesmo que seja possível não se deixar afetar por eles."

Paradoxalmente, nas grandes cidades os espaços apertam, se estendem e se adensam. Os blocos habitacionais concentram milhares de pessoas, enquanto as distâncias crescem. Muitos vizinhos, poucos conhecidos e alguns amigos. Encontram-se na ideologia do mercado e do consumo, os grandes centros comerciais e os Shopping-Centers, que reúnem em um único espaço tudo que é preciso para a vida social, sempre preservando o anonimato de quem vende e de quem compra. A lei do mercado econômico prevalece; o planejamento, nem tanto.

A destruição moderna do espaço rompeu esta solidariedade natural da proximidade. Nas cidades de hoje, nos blocos de habitação, em que os seres humanos se empilham uns sobre os outros, uns ao lado dos outros, todos são igualmente próximos de todos os demais; cada qual se encerre em sua casa para fugir à invasão dos ruídos, das sujeiras, das músicas induzidas dos arredores. Não há mais vizinho porque cada existência se sente parasita por todas as outras, vítimas de permanentes e intoleráveis agressões. O auxílio mútuo entre vizinhos deu lugar a uma forma nova de criminalidade..$^{51}$

A moradia como referência de família perde a sacralidade da convivência e da comunhão, do lar para dormitório e endereço. Novos modelos familiares surgem, tais como a família monopaternal e a homoafetiva. Trata-se, sobretudo, de olhar a realidade e buscar compreender estes impasses, criando recursos que contribuam não só para a eliminação de preconceitos, como também para diminuir conflitos que emergem na dinâmica intragrupo, com outros grupos sociais. É preciso ver que família deve servir à promoção da dignidade e à realização da

\footnotetext{
${ }^{50}$ CAIAFA, J., Aventura das cidades: ensaios e etnografias. Rio de Janeiro: FGV, 2007, p.117.

${ }^{51}$ GUSDORF, G., A agonia da nossa civilização. São Paulo: Convívio, 1978, p.33.
} 
personalidade de seus membros, integrando sentimentos, esperanças e valores, servindo como alicerce fundamental para o alcance de uma vida sadia.

Todavia a família, nos tempos atuais, está com menos tempo para se reunir, pois o tempo de trabalho que, com o advento tecnológico deveria diminuir, pela ideologia do capitalismo, tem apresentado um efeito contrário, com mais consumo, mais mobilidade, mais horas extras e mais trabalho em casa, inclusive aos domingos. Deve-se perceber que o trabalho é algo essencial na vida do ser humano e deve estar a seu serviço, não o escravizando. Assim, o trabalho comporta em si uma marca particular do ser humano e da humanidade; a marca de uma pessoa que opera numa comunidade de pessoas. ${ }^{52}$

Viver na cidade é entrar em constante confronto e dilemas com a cultura e seus valores. Valores absolutos e valores cultivados pela própria sociedade. Verificamos uma prática axiológica diante desses fatos, de modo mais emergente, os que põem em jogo a humanidade e a própria vida humana com direitos invioláveis.

Pode-se observar que todos nós, seres humanos, carregamos valores, pois estes estão no coração da cultura, sendo transmitidos dentro dela. A modernidade urbana transforma valores essenciais em valores móveis, fragmentários, subjetivos, conflituosos e plurais.

Sem dúvida uma das causas decisivas da confusão contemporânea em matéria de costumes, ou, como diziam os antigos, de vida direta, é que temos o sentimento de ter entrado em todos os domínios numa era inteiramente nova. Este sentimento encontra aliás cada dia confirmações na vida da cidade... Diante destas evoluções, uma primeira reação pode surgir: a que consiste em transportar-se aos bons velhos tempos, ao passado que por assim dizer tudo ia melhor, ao tempo perdido da moral... Ora, dessa nostalgia do passado, pode-se facilmente passar a uma atitude inversa, mas também unilateral. É nesse contexto social que as referências habituais desaparecem ou se esfumam, perdendo sua validade de fato, que nasce uma ilusão, mais ou menos geralmente partilhada. Porque de modo evidente as condições sociais da existência humana se modificaram, porque não é mais possível hoje reproduzir modelos antigos de ou da afeição conjugal, tira-se a conclusão de que nada é como antes, de que o homem moderno se encontra sem base de sabedoria ou de referências morais para conduzir sua existência. ${ }^{53}$

Os desafios pela preservação de identidades culturais dos diferentes grupos sociais são cada vez mais gigantescos. A modernidade é iminentemente urbana e à

52 CARTA ENCÍCLICA, Laborem Exercens de 1981. Disponível em: <http://www.vatican.va/ holy_father/john _ paul ii/encyclicals/ documents/hf_jp-ii_enc_14091981_laboremexercens_po. html >. Acesso em 7 fev. 2012.

53 VALADIER, P., Des repères pour agir. Paris: Desclée de Brouwer-Bellarmin, 1977, p.15. (T.N.) 
medida que avança, urbaniza a cultura. Hoje se fala da Cultura do espetáculo e da imagem. Imagens cada vez mais virtuais, que podem vir a substituir o encontro face a face.

As relações são cada vez mais mediadas pela tecnologia sofisticada, criando a ideia de que o outro não é necessário! Na realidade virtual, o outro pode até ser deletado, se chatear muito! Na maioria dos videogames, ganha quem mata mais! Para o computador, entretanto, ninguém morre; apenas alguns bits de informação são deletados. Mas para o garoto esperto, campeão de casa, "matei o cara com um bombardeio de laser!" Na realidade virtual se mata mais que peste bubônica na Idade Média! Talvez aqueles adolescentes de Brasília, que estavam apenas "brincando" de queimar índio, desconhecessem que a morte não é virtual, que a dor é real... Acostumados a deletar o que não interessa, tentaram deletar o índio virtualmente, mas o índio era real. Talvez, por isso, na decisão daquela juíza real, a culpa foi considerada virtual. ${ }^{54}$

Nesses tempos atuais, à medida que nos deparamos com a realidade, nossas identidades sociais, culturais, profissionais, religiosas e sexuais sofrem um processo de transformação contínuo.

$\mathrm{O}$ assunto identidade é pela própria natureza intangível e ambivalente, porém, algumas características identitárias parecem bastante evidentes nos tempos atuais, como, por exemplo, a subjetividade coletiva, as concepções de trabalho, as relações eu e o outro e a própria vida cotidiana. A mobilidade urbana do tipo virtual, crescente no tempo de agora, exprime a sua identidade pelo mundo da imagem e da plateia. O ser humano vai tornando-se consciente ou não de sua identidade conforme o seu "pertencimento" a grupos de ideias específicas locais e globais. Nos tempos de mobilidade, estas ideias não são garantidas por toda a vida, tornam-se negócios e revogáveis mediante as decisões e escolhas que o próprio indivíduo toma, conforme os caminhos que percorre e a maneira como age.

A identidade é sempre algo muito evasivo, quase um a priori, ou seja, uma realidade preexistente como, por exemplo, nossa identidade nacional: "somos daqui", "somos deste lugar", "pertencemos a este lugar". Durante a maior parte da história das sociedades humanas, as relações sociais e identitárias se mantiveram firmemente concentradas nos domínios da proximidade. Diante do processo de mobilidade, no entanto, a identidade, no aspecto sociocultural, torna plural, fragmentada, diversa e múltipla.

\footnotetext{
${ }^{54}$ TEIXEIRA, L. C. G., Realidade virtual e testemunho real. Tempo e Presença, v.20, 1998, ${ }^{\circ}$ 298, ISSN 1981-1810, p.14.
} 
A ideia de identidade humana é, muitas vezes, constituída a partir da crise de "pertencimento" e do esforço entre o "dever" e o "ser". Nos tempos atuais, com a globalização, temos, como consequência, enfrentar o desafio do "estar", pois a identidade passa a ser móvel e transitória, o que interfere severamente nas instituições que a representam, tais como família e Igreja, ou seja, a própria vida social. Busca-se, com muita rapidez, encontrar e criar novos grupos sociais com os quais se vivencie e identifique a construção de uma nova identidade "Um dos meios, dos instrumentos de jogar com a identidade é a Internet. De fato, na rede mundial de computadores podemos nos comunicar, criando até mesmo falsas identidades." $" 55$ O "estar" no mundo sem a segurança do pertencimento, induz ao uso da máscara, da assunção de outra personalidade, de outra identidade. Sem refletir, o indivíduo absorve as imposições de seu tempo. A fragilidade de que é acometida a identidade sociocultural impõe a seguinte reflexão: Quem realmente somos? Quem queremos ser? O que pretendemos com a exposição: apenas transitar no mundo virtual como voieur, nos escondermos de nós mesmos e de nossa realidade?

Buscamos construir e manter as referências de nossa nova identidade em movimento; juntamo-nos aos grupos igualmente móveis e velozes, construímos e tentamos manter vivos por um momento, mas não por muito tempo. Os celulares são suficientes e os fones de ouvido ajustados exibem nossa indiferença. $\mathrm{Na}$ admirável "pós-modernidade" das oportunidades, muitas delas fugazes e de segurança frágeis, as identidades rígidas e inegociáveis estão direcionadas ao isolamento e à perda de espaços de diálogo com a nova realidade que se impõe. Bauman diz que a dissolução da solidariedade e a sua substituição pela competição entregam as pessoas aos seus próprios recursos, distanciando-as dos apoios da comunidade. ${ }^{56}$

A globalização, num processo etnocêntrico - pela imposição de uma identidade única: "cidadão do mundo" e não daquele lugar específico e sobre o qual se justificam as lutas e as conquistas, a preservação e a valorização - quando não impõe, gera novas formas de identidade. Um dos mecanismos que favoreceram esse processo foi o livre mercado neoliberal, que permitiu, a cada

\footnotetext{
${ }^{55}$ BAUMAN, Z., Identidade, p.96.

${ }^{56}$ Ibid., p.35.
} 
indivíduo, capturar com liberdade a sua identidade, usando seus próprios recursos e ferramentas.

Identificar-se significa dar abrigo a um destino desconhecido que não se pode influenciar, e muito menos controlar. Hoje, as relações são bem mais de curta duração, os compromissos são bem mais eventuais e os caritativos em eventos de catástrofes, são exercidos, muitas vezes, de maneira passageira. Neste ambiente de vida, as identidades tornam-se aguçadas, sentidas, perturbadoras e ambivalentes. Houve um tempo em que a identidade humana de uma pessoa era determinada pelo papel produtivo que desempenhava. Poderíamos nos perguntar se tal identidade não se tornou a mesma no universo de mercado nos dias de hoje.

Com a globalização, a identidade se torna um assunto acalorado. Todos os marcos divisórios são cancelados, as biografias se tornam quebra-cabeças de soluções difíceis e mutáveis. Entretanto, o problema não são as peças individuais desse mosaico, mas como elas se encaixam umas nas outras. ${ }^{57}$

Se olharmos, rapidamente, ao longo da história mais recente, perceberemos que a identidade na modernidade possui características e alguns aspectos diferentes da pós-modernidade. Por exemplo, na modernidade, a preocupação com a identidade era de como construí-la para que permanecesse sólida e estável; a busca era de criação; os fatos eram registrados por fotografias que mostravam os acontecimentos como irreversíveis; a preocupação era de durabilidade. Na pósmodernidade, a identidade é uma constante busca; ela está sempre em movimento, evita-se a fixação; as opções estão em aberto; a reciclagem tomou lugar da criação; os fatos são registrados em vídeos que podem ser repensáveis e reutilizáveis; a preocupação está em evitar compromissos eternos. As identidades da sociedade atual podem ser adaptadas e a estratégia pós-moderna é a prevenção da fixação. Giddens chamou de "relação pura", "amor confluente" e "sexualidade plástica". 58

A força da sociedade e o seu poder sobre os indivíduos agora se baseiam no fato de ela ser "não-localizável" em sua atitude evasiva, versatilidade e volatilidade, na imprevisibilidade desorientadora de seus movimentos, na agilidade de ilusionista com que escapa das gaiolas mais resistentes e na habilidade com que desafia expectativas e volta atrás nas suas promessas, quer declaradas sem rodeios ou engenhosamente insinuadas. ${ }^{59}$

\footnotetext{
${ }^{57}$ BAUMAN, Z., Identidade, p.54.

${ }^{58}$ Id., A vida fragmentada: ensaios sobre a moral pós-moderna. Lisboa: Relógio D’água, 2007, p.95.

${ }_{59}$ BAUMAN, Z., op. cit., p.58 et. seq.
} 
Não sabemos se a satisfação de hoje, procurada, construída, será satisfatória amanhã. Vemos e aprendemos que o mundo e as pessoas ao nosso redor não são imunes às mudanças, “[...] até as formas básicas de relacionamento social estão passando por uma mutação. Das relações amorosas à religião, tudo se torna instável, líquido." ${ }^{60}$ A mobilidade sociocultural atual é fragmentada, descontínua e, às vezes, inconsequente. A humanidade contemporânea fala muitas vozes, quais ouvir?

O modo consumista requer que a satisfação precise ser, deva ser, ou, seja de qualquer forma instantânea, em que a utilidade tenha capacidade de proporcionar satisfação. A relação também se torna assim: sua durabilidade está condicionada à satisfação. Nunca se sentiu com tanta intensidade que o futuro é inesgotável, impermeável, incognoscível e está além do controle humano, atingindo diretamente o seu modo de estar no mundo. É a busca da essência da identidade “quem sou eu?". Liquefação e consumismo tendem a estar unidos na sociedade atual.

Esse modo reduzido de relacionar-se, "menos importuno", se ajusta a todo o resto ao líquido mundo moderno das identidades fluidas, o mundo em que o aspecto mais importante é acabar depressa, seguir em frente e começar de novo, o mundo de mercadorias gerando e alardeando sempre novos desejos tentadores a fim sufocar e esquecer os desejos de outrora. O prêmio é a liberdade de seguir adiante, mas uma opção que não temos a liberdade de fazer é parar de nos movimentar. Como Ralph Waldo Emerson já advertia muito tempo atrás, se você está esquiando sobre o gelo fino, a salvação está na velocidade. ${ }^{61}$

Diante desse ambiente de intensa fragmentação e dissolução, o ser humano pode estar sujeito a perder sua identidade e humanidade como ser de essência. Ele luta contra a ameaça de devorar e ao mesmo tempo também recusa a possibilidade de ser devorado. Muitas têm sido as críticas feitas por diferentes movimentos sociais a respeito da globalização neoliberal. A maioria delas origina-se dos movimentos que defendem as culturas regionais, sendo identidades locais, que são ameaçadas pelo desenvolvimento econômico. Sobre esse aspecto, Bauman assim se posiciona: “[...] Entretanto, eu sinto que, nesse mesmo movimento, parece haver uma forte ambivalência. A identidade pode ser um caminho para a emancipação, mas pode também ser uma forma de opressão."62

\footnotetext{
${ }^{60}$ BAUMAN, Z., Identidade, p.68.

${ }^{61}$ Ibid., p.76 et. seq.

${ }^{62}$ Ibid, p.94.
} 
A vida urbana atingiu um ponto que não há mais volta: dependemos uns dos outro, e a ótica escolhida oscila entre garantir mutuamente a vulnerabilidade de todos e a nossa segurança comum, ou seja, progredimos juntos ou afundamos juntos. Assim, o interesse e os princípios éticos de respeito e atenção mútuos de todos os seres humanos apontam para a mesma direção e exigem a mesma estratégia. Por isso, buscamos refletir a respeito das chances e dos desafios da humanização num contexto como o aqui descrito.

Nos tempos atuais, comprometer-se com uma única identidade é, de certo modo, arriscado. As identidades são para usar e exibir e não para manter. Somos forçados a moldar as nossas identidades. Mobilizados por modismos, temos dificuldades de firmar valores e, quando existem, a sua axiologia parece inversa. Somos consumidores em uma sociedade de consumo, pois estamos no mercado onde somos clientes e, ao mesmo tempo, mercadorias. Acabamos por adquirir o consumo também de nossas relações humanas e, por conseguinte, das nossas próprias identidades e das dos outros. Construímos uma sociedade urbana, móvel e profundamente individualizada.

O sofrimento ameaça-nos de três lados: vindo do nosso próprio corpo, que está votado ao declínio e à dissolução e que não pode sequer passar sem esses sinais de alarme que são a dor e a angústia; vindo do mundo exterior, que pode desencadear sobre nós as suas forças de destruição arrasadoras e implacáveis, e vindo, enfim, das nossas relações com os outros seres humanos. ${ }^{63}$

O engajamento instantâneo, o consumo rápido e o descarte imediato podem ter seus efeitos colaterais em nossas próprias identidades. Elas se deparam com a violência, com o medo, a exclusão, a rejeição, com o descarte, a pobreza, o lixo e, muitas vezes, temos medo de ficar sozinhos, indefesos e infelizes. As mudanças e os deslocamentos forçados pela globalização podem transformar os perfis urbanos, as famílias e instituições, retirando a segurança e a confiança nas pessoas.

Já que a diversidade cultural é, cada vez mais, o destino do mundo moderno, e o absolutismo étnico, uma característica regressiva da modernidade tardia, o maior perigo agora se origina das formas de identidade nacional e cultural - novas e antigas - que tentam assegurar a sua identidade, adotando versões fechadas da cultura e da comunidade e recusando o engajamento [...] nos difíceis problemas que surgem quando se tenta viver com a diferença. ${ }^{64}$

\footnotetext{
${ }^{63}$ BAUMAN, Z., A vida fragmentada: ensaios sobre a moral pós-moderna, p.111.

${ }^{64}$ STUART, H., Culture, Community, Nation. In: BAUMAN, Z., Identidade. Rio de Janeiro: Jorge Zahar, 2005, p.105.
} 
A necessidade de mudanças cada vez mais rápidas cria e modifica a concepção de tempo. Ele se torna sinal de oportunidades, de sucesso e de realizações econômicas e se desloca para as propriedades cada vez mais individuais e de necessidades. Pessoas de um mesmo lugar habitam tempos muitas vezes totalmente diferentes. "O tempo já não é um rio, mas uma coleção de pântanos e tanques de água.",65

A cidade moderna cria ofertas de diversão, como os parques; de consumo, os shopping centers; de entretenimento, os cinemas, que são sadios e ambíguos. Prazer e lazer tornam-se produtos de mercado, que são instantâneos. As pessoas, nesse contexto atual, em meio ao corre-corre da vida moderna, se voltam para a busca do prazer. O lazer tenta mostrar a possibilidade de transformar a atividade do mercado industrial em algo prazeroso, mas, ao mesmo tempo, denuncia que isso, muitas vezes, não é possível de acontecer. Hoje, porém, é por meio do lazer que alguns indivíduos estão programando as suas vidas, suas atividades, sonhos, realizações, tentando inseri-las na ordem econômica, enquanto outros buscam o sucesso profissional, disputam melhores salários, são absorvidos pelo stress no dia a dia e não dão importância ao lazer, ou não têm tempo para ele.

Muitas mudanças ocorreram ao longo do tempo nas cidades, mudanças culturais, religiosas, políticas, sociais, econômicas, advindas da pós-modernidade. O avanço tecnológico carrega uma grande participação nessas mudanças. Já pudemos vivenciar e continuaremos a ver mudanças radicais no trabalho, na moradia, na mobilidade social, pública e privada; mudanças, de modo especial, na configuração e na concepção de ser humano e suas relações com o mundo, com o outro e com Deus.

A falência do mundo moderno, que transita pela desconfiguração do espaço e do tempo, se resume e se define por este desaparecimento do senso dos valores, que acarretou uma desorientação total do homem num universo onde ele não consegue encontrar seu lugar. A técnica aumentou indefinidamente o poder $\mathrm{e}$ as possibilidades do homem, até permitir-lhe esta empreitada de deixar seu planeta de origem. $^{66}$

Importante ressaltar que a cidade não apresenta só problemas e dificuldades; ela exerce sobre a vida oportunidades e sensações. É um paradoxo de ilusão e sofrimento, de atração e repulsão; paradoxo de densidade urbana que facilita o

\footnotetext{
${ }^{65}$ BAUMAN, Z., A vida fragmentada: ensaios sobre a moral pós-moderna, p.96.

${ }^{66}$ GUSDORF, G., A agonia da nossa civilização, p.84.
} 
luxo e o lixo. Por toda parte, unem-se iguais e diferentes. Somos reflexos de nossos espaços urbanos de nossas cidades computadorizadas e virtuais. É o império das tecnologias, da força do sistema neoliberal com seus avatares culturais.

Os espaços invisíveis formados pelas redes de computadores e frequentados por [...] jovens são frequentemente chamados de ciberespaço e de espaço dos fluxos. São espaços nos quais tudo e todos podem se interconectar com uma mobilidade nunca sequer anteriormente sonhada. ${ }^{67}$

Contudo, a velocidade com que as mudanças ocorrem disputa com a competência para se planejar a vida nas cidades. A falta de planejamento causa muitos problemas sociais, como criminalidade, desemprego, poluição, destruição do meio-ambiente, desigualdades sociais, fome, mendicância, sub-habitações e depreciação da natureza humana.

Com o "encolhimento" do planeta, também em virtude dos meios de transportes cada vez mais rápidos, com a velocidade da produção cultural, do saber e da informação, o turismo passa a ser mais valorizado, pois cresceu nas pessoas o desejo de conhecer outras terras, outros costumes. As diferentes culturas se aproximaram, tornando um mundo mais interessado em entender os problemas e as dificuldades dos outros. Talvez seja possível, a partir daí, desenvolver uma sociedade não só conhecedora dos problemas globais, como também mais participativa nas soluções desses problemas, mais humana e solidária.

Os novos espaços virtuais não são espaços pós-humanos. Não são formados exclusivamente por sua infraestrutura tecnológica. São formados por redes de pessoas que interagem com os mais variados propósitos. [...] Eles existem não somente porque existem máquinas e tecnologia, mas principalmente porque existem pessoas interagindo com outras pessoas. ${ }^{68}$

A mudança, a tecnologia, as várias formas de mobilidade, o desenvolvimento devem ser valorizados, aproveitados e incentivados de maneira que possam favorecer a construção de uma sociedade cada vez mais solidária e humana. Não se pode ter medo da tecnologia, da modernidade, do mundo midiático; seria o mesmo que render-se ao medo. É preciso compreender que essa nova realidade é resultante da própria evolução do ser humano e simboliza respostas para as suas buscas. A cada tempo, o ser humano, situado e

\footnotetext{
${ }^{67}$ NICOLACI-DA-COSTA. A. M., Espaços virtuais: pós-humanos? In: ANDRADE, P. F. C. (org) \& NEUTZLING, I. (org), Uma sociedade pós-humana: possibilidades e limites das nanotecnologias. São Leopoldo: Unisinos, 2009, p.13.

${ }^{68}$ Ibid., p.20.
} 
historicizado, viu-se diante de desafios, muitos por ele mesmo criados. O novo exige reformulações que se traduzem em soluções para as necessidades humanas fomentadas.

A nuvem que nos pare é a aceleração tecnológica, que dilui as fronteiras entre natureza e cultura, entre sujeito e objeto, entre interioridade, e lança a civilização contemporânea num estado de indeterminação cada vez mais condensada, equivalente a uma mutação. ${ }^{69}$

Vemos que para essa nova luta é imprescindível o acompanhamento da ética social. As relações sociais são cada vez mais computadorizadas, compartilhadas em todo o mundo, com pessoas conhecidas e desconhecidas, como no facebook, por exemplo, exigindo, cada vez mais, a inserção da ética geradora de comportamentos capazes de conduzir esse novo tipo de relacionamento virtual, não permitido atitudes desumanas, imorais e destrutivas.

A religião, nesse ambiente de mobilidade, pode ser uma grande incentivadora da construção de identidades mais humanizadas, acompanhando-as, assumindo o papel de fazer com que o ser humano não perca o seu valor, a sua espiritualidade e a sua necessidade de se relacionar com o próximo. Por isso, as Igrejas precisam avançar, inclusive, nesse ambiente das tecnologias, de modo a dialogarem com essa nova realidade, oportunizando que os indivíduos possam também se apropriar de seu discurso de modo a chamar a humanidade ao uso do bom senso, do respeito, da compreensão, da ética e da caridade.

[...] o que caracteriza a religiosidade das sociedades modernas é a dinâmica do movimento, mobilidade e dispersão de crenças. É uma dinâmica que tensiona com a figura típica e estável do homem religioso, que é sua condição de praticante. $\mathrm{Na}$ paisagem religiosa cristã, a figura do praticante foi sempre a mais evidente: do praticante regular que se insere numa bem definida territorialidade comunitária. Essa "figura emblemática" do praticante tende a pulverizar-se na Modernidade, com a nova dinâmica da "mobilidade das pertenças, com a desterritorialização das comunidades, com a desregulação dos procedimentos da transmissão religiosa e com a individualização das formas de identificação." ${ }^{\text {70 }}$

Essa atual sociedade pluralista, secularizada e fragmentada constitui um desafio para a convivência humana e para as formações religiosas, pois a autocomunicação com Deus só chega a sua meta quando é acolhida pelo ser humano, um ser de cultura.

\footnotetext{
${ }^{69}$ ANDRADE, P. F. C. (org) \& NEUTZLING, I. (org), Uma sociedade pós-humana: possibilidades e limites das nanotecnologias, p.103.

${ }^{70}$ HERVIEU-LÉGER, D., O peregrino e o convertido: a religião em movimento. Petrópolis-RJ: Vozes, 2008, p.10.
} 
A leitura sob a ótica antropológica da cultura nos leva a uma variedade de culturas e não consegue explicar o ponto comum entre elas e de onde surgiram. Já a filosofia nos aponta o ser humano como aquele ser que produz cultura. Por ser o homem um ser-no-mundo, só é capaz de se realizar através do mundo, humanizando o mundo. Tal processo é feito mediante a cultura. Na verdade é o ser humano que dá significado e finalidade ao mundo se expressando nele.

Pois a comunidade humana se constitui e se compreende sempre no interior de um horizonte cultural transmitido. Habitamos um mundo social criado por outros, com sua linguagem, símbolos, papéis e instituições, realizações políticas e econômicas. E só no interior deste horizonte cultural histórico e contextualizado encaramos, entendemos e avaliamos a realidade. ${ }^{71}$

A globalização é um fenômeno cultural, pois atinge, quase todos os seres humanos, todas as culturas, todas as sociedades, mesmo que desigualmente. Nenhuma cultura ou sociedade pode ignorar as outras. A teia da diversidade de culturas se integra, se une; as culturas se tornam dependentes uma das outras. Devemos pensar em como evangelizar em uma diversidade de culturas.

A Igreja não pode ignorar situação do mundo e menos ainda se omitir na construção do futuro da humanidade. Vivemos um período globalizado da história. Paz, justiça, dignidade humana, solidariedade, política ecológica, tudo isso, sem o qual a vida humana pode se tornar insuportável, como nunca depende do compromisso de todos. ${ }^{72}$

Muitas coisas na contemporaneidade são explicadas pela razão e movidas por fortes emoções. A razão e a técnica não são suficientes para explicar os enigmas e mistérios da realidade, porém só compreenderemos o ser humano na abertura com o Transcendente.

A perspectiva antropológica que compreende o ser humano como alguém aberto a toda realidade, sempre a superá-la e a transcendê-la, com novas questões e indagações, desejos e anseios, determinando assim sua experiência do mundo e identificando-o como um ser inquieto, constitui a base de sua vida religiosa e daquilo que as religiões representam de Deus. A pessoa humana pressupõe em todo o seu ser e agir um estar remetida a um Outro, dela diferente porque infinito e transcendente, mesmo que não possa nomeá-lo. ${ }^{73}$

A palavra de Deus tornou-se para alguns sem grande significância ou passou a ser considerada como produto de sonhos humanos, mercadoria de ideia, de autoajuda, de utopias. Porém, o ser humano, pela sua condição de inacabado e aberto ao Transcendente, acaba por se perguntar pelo sentido último de sua

\footnotetext{
${ }^{71}$ HERVIEU-LÉGER, D., O peregrino e o convertido: a religião em movimento, p.17.

${ }^{72}$ Ibid., p.35.

${ }^{73}$ Ibid., p.42.
} 
existência. Ele é capaz de tomar consciência, através do exercício de sua liberdade, almejada tão intensamente no mundo de hoje, de que é o responsável pela construção de sua própria autobiografia e de sua história. A humanidade de Jesus, manifestada em sua vida no mundo, revela, mediante a sua história, a identidade última e a estrutura subjacente de todo ser criado.

As profundas mudanças de cunho sociocultural que sacodem o planeta, atingindo instituições como a família, a universidade, a organização política, a vida econômica, também não deixam de fazer sentir seus efeitos no âmbito da religião. Já se afirmou que a velocidade de tais transformações não permite às instituições se adequar aos novos desafios que surgem, gerando assim, em todas elas, um mal estar sentido por todos nós como manifestação de uma crise que não conseguimos definir com precisão. ${ }^{74}$

A população atual é diferente, variada; existem vários contrastes e vários estilos de vida. Cada povo com suas características únicas. Nesse contexto social, visualiza-se a grandeza de características, a beleza do diferente, o universo de estilos de vidas e a capacidade de união do ser humano. Habermas afirma:

sem aquilo que move os sentimentos morais da obrigação e da culpa, da censura e do perdão, sem o sentimento de libertação conferido pelo respeito moral, sem a sensação gratificante proporcionada pelo apoio solidário e sem a opressão da falha moral, sem a 'amabilidade' que nos permite abordar situações de conflito e contradição com o mínimo de civilidade, perceberíamos o universo povoado pelos seres humanos como algo insuportável. ${ }^{75}$

Não existe nenhum motivo que impeça de reconhecermos a beleza das diferentes formas de relacionamento humano, da sua criatividade em seu dia a dia, da sua afeição pela modernidade, do seu grande estímulo de querer sempre conhecer coisas novas, pessoas novas, sem sair de casa e sem ser super-homens. O ser humano é essa mistura de conhecimentos, é essa sede de mudança e é essa diversidade de possibilidades.

Não devemos separar a realidade da Igreja da sociedade, pois elas são realidades impermeáveis; uma sofre influência da outra, se ajudam, se constroem, se completam, se conflitam, enfim, se integram continuamente ao longo da história. Atualmente, as fortes e sucessivas mudanças socioculturais que estão acorrendo em nossa sociedade têm proporcionado sérios impactos na Igreja, sendo ela contestada e desafiada constantemente por uma cultura secularizada e

\footnotetext{
${ }^{74}$ HERVIEU-LÉGER, D., O peregrino e o convertido: a religião em movimento, p.107.

${ }^{75}$ HABERMAS, J., O futuro da natureza humana. São Paulo: Martins Fontes, 2004, p.100.
} 
pluralista. De acordo com Miranda, Hans Küng apresenta "quatro imperativos éticos encontrados em todas as tradições religiosas":

[...] respeitar a vida; agir com honestidade; falar com sinceridade; respeitar e amar o semelhante. Tais imperativos estão fundamentados em dois princípios fundamentais. O primeiro é a regra áurea: "o que não desejas para ti mesmo também não o faças a outros". O segundo é a regra humanitária: "todo ser humano deve ser tratado humanamente." ${ }^{, 76}$

Juntos caminhamos rumo ao futuro da humanidade, juntos criaremos esse futuro, juntos somos todos responsáveis por ele. Paz, justiça, dignidade humana, solidariedade, política ecológica, tudo isso, sem o qual a vida humana pode se tornar insuportável, depende como nunca do compromisso de todos. E aqui o Cristianismo tem algo a dizer, bem como as demais religiões. Mas, todas elas só darão a sua contribuição à atual sociedade secularizada e regida pela economia na medida em que forem dignas de credibilidade, respeitadas por nossos contemporâneos. No caso do Cristianismo, não basta apenas proclamar sua Verdade e apresentar ao mundo a atraente figura de Jesus Cristo, suas palavras e sua vida. Trata-se, sobretudo, de viver o que se professa, anunciar e testemunhar, já que a verdade última da fé cristã é o Amor, realidade a ser vivida e não apenas sabida. Seguir a verdade do amor (Cf. Ef 4,15) ou praticar a verdade (Cf. 1Jo 1,6) eis a condição básica da contribuição cristã para a paz e a justiça no mundo. Só assim estará fazendo refluir para a sociedade sua universalidade salvífica. ${ }^{77}$

Como visto, buscamos tratar, neste capítulo do surgimento das cidades e com ela o processo de urbanização, que tem como característica clássica o sedentarismo físico. Este processo vem, no entanto, experimentando uma intensa movimentação que ultrapassa o estado físico, incluindo o virtual, suas implicações e motivações a partir do desenvolvimento tecnológico e urbanizado. Concluindo esta fase do estudo, somos conduzidos a considerar que as cidades, por terem sido a sede das primeiras indústrias, atraíram também diferentes meios de relações sociais e provocaram novos estilos de vida.

O mais importante é verificar a situação policêntrica da cidade atual, colocando o ser humano sujeito a um constante movimento. "A exemplo da divisão de células-tronco em novas células, a cidade policêntrica cria centros

\footnotetext{
${ }^{76}$ MIRANDA, M. F., Igreja e Sociedade. São Paulo: Paulinas, 2009, p.331.

${ }^{77}$ Ibid., p.332.
} 
urbanos menores e cada vez mais autônomos."78 Ao finalizar este capítulo, convidamos também à reflexão sobre os efeitos que esse novo estilo de vida nômade produz na vida humana, sua interferência nas suas relações inter e intrapessoal, sua identidade cultural e seus valores.

Vimos, também, a força da mobilidade urbana em nossa realidade atual. O processo de mobilidade, em suas linhas gerais, não é um fenômeno recente. Desde o princípio, somos seres em movimento, porém jamais nos movemos de modo tão rápido quanto nesse tempo atual. A mobilidade globalizante acontece, no aspecto físico, de maneira desestabilizante, no aspecto axiológico, quando a ética torna-se mutante e individualizada, com invasão na esfera de valores, no eixo antropológico referente à crise de identidade do ser humano e, religiosa, na construção de verdadeiras comunidades.

Também destacamos que o conceito de urbanismo não é unívoco e que possui graus diferentes de presença nas cidades. Já a realidade sociocultural nos mostra uma vertente urbana plural, múltipla, diversa e fragmentada; carrega uma série de desafios a serem superados quando confrontados à luz da fé cristã, tratando-se do ser humano.

Em síntese, vimos neste primeiro capítulo, o ser humano atual, marcado pela cultura urbana e globalizada. Esta, por sua vez, apresenta uma característica marcante: a intensa mobilidade. Trata-se de novas formas e modos de compreensão de toda a vida, modo este caracterizado não mais pelo estável, pelo fixo, pelo estabelecido. Mas uma nova época, em que a compreensão da vida é marcada pelo movimento, pelo transitório e instável, pela novidade mutante, por vínculos temporários, parcerias momentâneas, identidades flácidas.

No caso específico da mobilidade urbana atual, já não assistimos, portanto, ao desejo do estável, à sede de segurança dentro dos muros da cidade. Assistimos a uma espécie de sede pelo deserto, pelo nomadismo, volta de uma história antiga e descoberta da mobilidade como estilo de vida. O fenômeno da mobilidade tornou-se mais agudo nas últimas décadas, apresentando várias formas de captação e compreensão, porém, com um ponto em comum: a mobilidade não afeta apenas um aspecto ou outro, mas de modo especial a concepção de ser humano no que atinge sua identidade e humanização. Neste sentido, procuraremos

\footnotetext{
${ }^{78}$ FREITAG, B., Teorias da cidade. Campinas: Papirus, 2006, p.177.
} 
analisar, a seguir, o ser humano considerando sua natureza de criatura, suas especificidades, marcado pela mobilidade atual e, tentar identificar se essa nova conjuntura sociocultural de mobilidade tem possibilitado o desenvolvimento de sua humanização ou não.

A humanização é a palavra-chave a conduzir nosso estudo e, sobre esse tema, aprofundaremos no próximo capítulo. Buscaremos conduzir nossos argumentos guiados pela pergunta fundamental: este processo de mutação pelo qual vive a sociedade atual ajuda ou cerceia a humanização do homem e da mulher nômades no sentido descrito neste capítulo? Com base nas principais afirmações, da antropologia cristã, buscaremos encaminhar algumas respostas. 


\section{2 \\ O SER HUMANO À LUZ DA ANTROPOLOGIA CRISTÃ - A MOBILIDADE E O SER HUMANO: PARÂMETROS}

Após delinearmos algumas características da sociedade atual, com destaque para a mobilidade, somos agora desafiados a pensar teologicamente a respeito das chances e dos desafios que uma realidade como essa traz para a humanização dos que nela vivem. Faremos isso a partir das categorias centrais da antropologia teológica, buscando, com base no diálogo-confronto entre elas e as questões trazidas pela mobilidade urbana atual, responder à questão central desta dissertação, que é a humanização do ser humano. Assim o fazemos porque estamos certos de que

Tudo o que faz parte da existência humana e contribui para que essa existência seja elevada, desenvolvida, aperfeiçoada, estimulando o ser humano a crescer em humanidade, em criatividade e em liberdade, possibilitando mais vida e mais amor, tudo isso é integrado, sob a ótica da fé cristã, num processo ascendente, dinamizado pela graça divina manifestada em Jesus Cristo. ${ }^{157}$

Poderíamos falar sobre o ser humano sob diferentes pontos de vista. No entanto, é o ser humano, na mobilidade urbana atual, nosso sujeito de estudo. É importante, no início desse segundo capítulo, deixar claro que abordaremos esse ser humano em suas relações com Deus Uno e Trino, revelado em Jesus Cristo, ou seja, aquilo que somos à luz de Jesus Cristo, revelador de Deus. Assim, veremos o ser humano em sua totalidade.

Neste sentido, convém recordar que, no primeiro capítulo, insistimos na afirmação de que o estágio atual da urbanização se caracteriza, entre outros aspectos, pela mobilidade, que deixou de ser apenas física para se tornar também sociocultural. As pessoas se movimentam não apenas para cumprir suas tarefas cotidianas; a mobilidade se tornou também uma condição de compreensão da vida. As cidades atuais, mencionávamos logo no início do primeiro capítulo, "oferecem um novo tipo de nomadismo aos que estão em casa", de modo que movimento e estabilidade, nomadismo e sedentarismo se encontram numa nova configuração de cidade e de pessoas. ${ }^{158}$

\footnotetext{
${ }^{157}$ BONELLI, M. A. G., Pessoa humana: liberdade em processo de evolução dinamizado pela graça. In: RUBIO, A. G. (org.) \& AMADO, J. P. (org.), Fé Cristã e pensamento evolucionista: aproximações teológico-pastorais a um tema desafiador. São Paulo: Paulinas, 2012, p.188.

${ }_{158}$ LEMOS, A., Cultura da Mobilidade. Porto Alegre: Revista FAMECOS, nº40, dezembro de 2009, p.30.
} 
Estamos diante de um novo momento na história da humanidade, uma época em que o movimento do ser humano urbano atual reconfigura a sociedade e, de modo especial, marca e define um novo ser nas relações humanas e sociais. Este ser está em constante mudança, em movimento permanente, acelerado e profundo e, nesse processo, presencia-se também, a reconstrução de suas relações, da sua identidade, do seu comportamento e da sua visão de mundo. "Um subjetivismo radicalmente individualista predomina na visão do ser humano."159 Dessa maneira, ele vai redesenhando os espaços urbanos atuais e definindo um novo nomadismo urbano.

Ao analisar esta realidade, manifestamos, desde já, uma cautela, pois sempre corremos o risco de avaliar as mudanças a partir do que consideramos correto ou lógico; analisamos determinada realidade a partir de nosso ponto de vista, de nosso local social, eclesial e histórico. No caso desta dissertação, o risco do condicionamento histórico-cultural também é visível e além do mais, nesse ambiente de aguda mobilidade, também nós, produtores da pesquisa, somos “migrantes". Por isso, desejamos deixar claro, desde já, o empenho metodológico em nos distanciarmos para que os julgamentos assumam o desejável caráter objetivo.

Para fazermos essa análise, dividiremos esse capítulo em dois grandes momentos. Em um primeiro momento, destacaremos as principais características do ser humano, conforme a antropologia teológica. Em seguida, já a título de conclusão do capítulo, analisaremos as possibilidades de humanização ou não que o ser humano atual encontra nos ambientes urbanos, tal qual se configuram em nossos dias.

Insistimos bastante no critério da humanização por perceber que este se refere ao que, de modo simples, podemos chamar de mentalidade. De fato, dentre todas as mudanças, nenhuma supera a importância que têm as da mentalidade humana. É uma revolução sobre como se concebe o indivíduo e como se fundam laços e relações com os outros e com Deus. É sensível o fato de que as pessoas de hoje já não são como até há poucos anos, os jovens mudam e as crianças surpreendem. Na verdade, o que muda nos ambientes urbanos atuais são as crenças, os valores e as identidades. As pessoas já não acreditam naquilo em que

${ }^{159}$ RUBIO, A. G., Unidade na pluralidade: o ser humano à luz da fé e da reflexão cristãs. São Paulo: Loyola, 2001, p.46. 
antes acreditavam, nem dão importância ao que antes valorizavam. "A verdade não é mais aceita só pelo fato de ter sido indicada ou imposta de 'fora' (autoridade divina ou humana)."160 No mundo urbano, ao viver da cultura da tecnociência, emerge um novo tipo de ser humano, que se apropria cada vez mais de recursos tecnológicos, dos meios virtuais, para sua comunicação.

A pergunta sobre o que é o ser humano sempre esteve na pauta das discussões ao longo da história, como o questionamento mais profundo; uma questão que fascina, causa admiração, inquieta e desafia cada um de nós. Soma-se hoje a seguinte dúvida: será que todas as mudanças que ocorrem no mundo urbano permitem ao ser humano desenvolver suas potencialidades? O ser humano encontra, no atual estágio da urbanização, condições para realizar-se como humano ou, ao contrário, vê-se tolhido nestas potencialidades? Não esgotaremos toda a reflexão que a antropologia teológica apresenta sobre o ser humano. Limitar-nos-emos a abordar as principais afirmações, a saber, sua condição de criatura, de pessoa, sua co-humanidade, a restauração em Cristo e a santificação no Espírito. No terceiro capítulo, trataremos de verificar em que sentido a mobilidade urbana atual pode contribuir e em que sentido não pode fazê-lo para a humanização deste ser humano definido ao longo de nosso estudo.

Analisaremos aspectos religiosos e sociais relacionados à humanização, como as condições e possibilidades em que esse processo resiste, permanece ou é penalizado diante da frenética mobilidade imposta pela vida urbana atual. Assim, somos instados a destacar aspectos do ser humano que consideramos importantes para a compreensão e o sentido que pretendemos a ele dar em sua totalidade, em sua relação consigo mesmo, com o outro e com o Deus Uno e Trino, revelado por Jesus Cristo. "Sem a referência a Jesus Cristo, é impossível comunicar a verdade cristã sobre o ser humano, pois Jesus Cristo é o cabeça e o modelo da nova humanidade." 161

Neste capítulo, buscamos trazer elementos que, a nosso ver, contribuem para o estudo pretendido. Assim, iremos analisar os seguintes aspectos: o ser humano como criatura, ser vivente, capacitado para a Eleição e Aliança, aberto positivamente aos outros, aberto ao Divino e Absoluto, pessoa, ser que é corpo,

\footnotetext{
${ }^{160}$ RUBIO, A. G., Unidade na pluralidade: o ser humano à luz da fé e da reflexão cristãs, p.35.

${ }^{161}$ Ibid., p.91.
} 
aberto ao futuro, em busca da verdade, restaurado em Jesus Cristo e santificado no Espírito e, por fim, o ser humano e a mobilidade, com seus desafios.

\section{1 \\ Criatura}

Uma das afirmações básicas da antropologia teológica cristã consiste em destacar o ser humano como criatura. Pertence ao núcleo da fé cristã, a declaração de que o ser humano foi criado à imagem e semelhança de Deus. "Uma determinação fundamental do ser humano, que nunca o abandona, é sua criaturalidade."162 Nessa dimensão, observa-se a gratuidade de Deus para com o ser humano, que o cria do nada, simplesmente por bondade e amor. "Eu te suplico, meu filho, contempla o céu e a terra; reflete bem que tudo que vês, Deus o criou do nada, assim como todos os homens" (2Mac 7, 28).

A partir do princípio de que o ser humano é imagem e semelhança de Deus no mundo, ele possui o domínio sobre as outras criações de Deus. Esta foi a grande dimensão da graça de Deus para com a criatura, a liberdade para conduzir a sua vida. Deus concebeu o homem como um ser racional e de responsabilidade, também para que possa conduzir sua vida e a do mundo rumo ao projeto de Deus manifesto, por exemplo, nos relatos criacionais.

Por ser Deus o Criador e o ser humano a criatura que se assemelha ao Criador, ele está em completa necessidade de Deus, pois precisa conduzir a sua vida, utilizar dos recursos naturais a ele oferecidos, com responsabilidade e de forma semelhante a como Deus as utilizaria. Caso contrário, o ser estaria se afastando cada vez mais da sua origem e de sua essência. Entretanto, o ser humano é livre para decidir aproximar-se ou afastar-se de sua essência, que é Deus; ele também é livre para decidir pela vida ou pela morte, afinal, é um ser de decisão, de relação e de resposta.

Deus não obriga a aceitar o seu dom, precisamente porque Deus é Ágape. Existe, pois, o tremendo risco de o homem responder negativamente, frustrando a maneira mais íntima vocação, no âmbito da salvação e no âmbito da criação inseparavelmente unidos. A decisão do homem é sempre respeitada por um Deus que cria o homem à sua imagem para que possa amadurecer a sua decisão e responder com liberdade. ${ }^{163}$

${ }^{162}$ LADARIA, L. F., Introdução à Antropologia Teológica. São Paulo: Loyola, 1998, p.37.

${ }^{163}$ RUBIO, A. G., Unidade na pluralidade: o ser humano à luz da fé e da reflexão cristãs, p.286. 
Deus criou o ser humano à sua imagem e semelhança, não para a morte, mas para a vida, para o amor, para a plenitude. Essa é a grande intenção do coração de Deus, por isso, Ele irá jamais se afastar-se do ser humano, da sua imagem, apesar de respeitar a sua decisão. Dessa maneira, Rubio irá afirmar que "o destino do homem e o destino do mundo estão inseparavelmente unidos." ${ }^{164} \mathrm{O}$ ser humano criado por Deus tem a capacidade e é chamado a colaborar com seu Criador, a cocriar a realidade a sua volta e, pouco a pouco, fazer surgir um novo horizonte de pensar e agir.

O ser humano, pelo fato de ser criado, está destinado a ser ele mesmo. Daí, a questionabilidade é a estrutura do ser humano: o ser humano é essencialmente uma questão, uma busca, de si mesmo. Nessa questão de sua existência, e juntamente com ela, está a questão de Deus. ${ }^{165}$

A relação da criatura com Deus Criador e a resposta a essa busca se deu de diferentes formas, em diferentes períodos históricos e lugares. No Antigo Testamento, o ser humano, criatura de Deus, responde ao chamado libertador pela fé. Essa realidade era a teocêntrica. Entretanto, o movimento da relação do ser humano com Deus acontece na história e o êxodo demonstra o início dessa experiência do ser humano, quando Deus irá revelar a sua graça, sua bondade e misericórdia para com a criatura, mediante a libertação e, com ela, a aliança - o compromisso divino que estabelece com sua obra, feita à sua imagem e semelhança. Para acolher tamanha experiência e a traduzir para as realidades humanas sociais, culturais e religiosas, surgiram os diversos relatos veterotestamentários que abordaremos em seguida de forma sintética.

No relato da tradição Javista, a imagem de Abraão é considerada como a imagem da bênção feita pela aliança de Deus para com o seu povo. Essa bênção concedida, gratuitamente, ao povo é a salvação. A tradição Eloista se mostra de uma forma mais pessimista, quando o povo se rebela contra Deus e tende a afastar-se Dele. A importância da Lei fica ainda mais evidenciada para alcançar a salvação. Com a tradição Deuteronomista, a salvação torna-se concretizada e eternizada com o cumprimento da Lei. "O Deus de Israel revela-se como salvador, propondo ao homem o caminho de saída e dando-lhe ao mesmo tempo a

\footnotetext{
${ }^{164}$ RUBIO, A. G., Unidade na pluralidade: o ser humano à luz da fé e da reflexão cristãs, p.293.

${ }^{165}$ MOLTMANN, J., Teologia da Esperança: estudos sobre os fundamentos e as consequências de uma escatologia cristã. $3^{\text {a }}$ ed. São Paulo: Loyola, 2005, p.84.
} 
capacidade concreta de segui-lo, encaminhando-se, assim, para a situação positiva de salvação." 166

$\mathrm{Na}$ tradição Sacerdotal, o grande objetivo fica sendo o de apresentar coragem e esperança para quem se encontra no exílio. Os profetas vão pretender denunciar tudo aquilo que afasta o ser humano dos objetivos de Deus, como as práticas da magia que apareciam sobre a região de Israel e até mesmo a Lei e o culto, que, quando usados incorretamente, afastam-se da verdadeira prática da salvação. Naquele período, a Lei e o culto passaram a ser comercializados e o povo esquece-se de que a salvação provém unicamente de Deus. "O homem todo homem - precisa de salvação. E só em Iahweh, o Deus salvador, o homem encontra, de fato, a salvação."167

A salvação só pode ser conduzida por Deus. Não são o culto e a lei, por si, que oferecem a salvação. $O$ fato de pertencer ao povo de Israel não significava que a salvação estava garantida, até porque, como mostrou Jesus Cristo, Deus é universal e se dá a toda criatura. Ele anuncia e denuncia, por meio de seus profetas, as falsas ideias direcionadas a Ele, surgindo conflitos e perseguições, porém, ao mesmo tempo, promove, naqueles que aceitam sua ação, um espírito de gratidão e louvor, podendo ser observado nos salmos e cânticos de louvores. Esse espírito irá despertar no ser humano uma concepção da obra escatológica do Criador na história da humanidade. "Podemos afirmar que a criação está intrinsecamente voltada para a encarnação."168

A criação, segundo a fé bíblico-cristã, significa que Deus pessoal, pela sua iniciativa livre, dá o ser, o existir e a capacidade para agir, de maneira transcendental e não categorial, a tudo quanto existe fora dele. A criação abrange a realidade inteira extradivina. Assim, não está situada apenas no início, mas também na continuação e na consumação do cosmos e de cada criatura criada. ${ }^{169}$

Deus concedeu ao ser humano, sua criatura, a salvação e a sabedoria. É mediante a sabedoria que o ser humano alcança a salvação, se aproxima de Deus. Existem dois momentos para se definir a sabedoria: o primeiro, antes do exílio, quando era considerada como autossuficiência - a razão humana é a responsável por conduzir o ser humano em seus atos. Este não tinha a intenção de superar os

\footnotetext{
${ }^{166}$ RUBIO, A. G., Unidade na pluralidade: o ser humano à luz da fé e da reflexão cristãs, p.175.

${ }^{167}$ Ibid., p. 127.

${ }^{168}$ MIRANDA, M. F., A salvação de Jesus Cristo: a doutrina da graça. São Paulo: Loyola, 2004, p.44.

${ }^{169}$ RUBIO, A. G., op. cit., p.277.
} 
seus limites com o objetivo de alcançar a Deus; o segundo momento para se definir a sabedoria ocorre no período pós-exílio, pois o ser humano procura aceitar os desígnios de Deus. O ser humano, após ter vivido uma situação de escravidão, repensa a sua racionalidade e percebe a sua dependência diante da sabedoria de Deus. "Para os profetas só existe uma via segura de acesso a Deus: a que passa através da palavra Dele, da sua vontade, da sua lei."170

Nessa tradição Sacerdotal, o interesse pelo futuro é despertado e os grandes incentivadores desse período escatológico são os profetas. Eles pregam a esperança no Deus salvador e rejeitam a realidade presente vivida pelo povo de Israel. Para eles, o mundo já havia sido corrompido pelo pecado e por injustiças, mas a grande espera desses seres humanos era pela Jerusalém celeste, que traria a salvação do ser humano, que se deixou ser seduzido pelas perversões humanas.

\begin{abstract}
Alguma coisa começou e está germinando de modo escondido, misterioso. E o povo que caminhava em trevas viu uma grande luz (Mt 4, 15-16). Gostaríamos que esta luz fosse mais esplendorosa e radiante. Mas agora é o momento em que cabe a nós tomar o lugar e procurar fazer com que essa luz, ainda que pequena, não fique escondida debaixo do candeeiro. E enquanto ela cresce, ilumina a casa toda e se estende ao mundo inteiro, as palavras dos profetas nos animam a esperar e a crer que um dia os nossos sonhos e ilusões se tornarão realidade. ${ }^{171}$
\end{abstract}

Essa criatura de Deus, o ser humano, é um ser de complexidade e finitude, cuja vocação existencial é caminhar para o Criador que, para ele, traçou um projeto de salvação baseado no amor e na caridade, inspirados pela fé. Entender o ser humano como criatura e os principais aspectos que o constituem é imprescindível para que possamos situá-lo na conjuntura existencial em que vive hoje, quando somos chamados a refletir e agir. No sentido de subsidiar o estudo para uma estruturação da resposta que pretendemos buscar, se existe possibilidade de humanização do ser humano neste ambiente atual de urbanização aguda, em que a mobilidade é predominante critério de constituição da vida, é que passaremos a abordar esses aspectos que definem e constituem a natureza do ser humano.

De fato, muitas são as implicações a respeito da condição criatural do ser humano. No entanto, a mobilidade, tem assumido destaque nestes últimos tempos,

\footnotetext{
${ }^{170}$ SICRE, J. L., Profetismo em Israel: o profeta, os profetas, a mensagem. Petrópolis: Vozes, 2002, p.401.

${ }^{171}$ Ibid., p.496.
} 
em que, diante de tamanhas transformações, se tornou uma característica e, ao mesmo tempo, uma condição de existência.

Como criatura, o ser humano não possui nem a origem nem a finalidade em si mesmo. Ele é sempre um ser referido ao Criador; é um ser constitutivamente voltado para Aquele que é a fonte e a meta de sua existência. É, na verdade, um ser igualmente referido aos outros seres humanos e a toda criação. A referência aos demais seres humanos aparece de modo destacável na diversidade homemmulher. De acordo com o relato bíblico, mesmo tendo completado toda criação, o ser homem não encontra quem o complete, a não ser quando lhe é apresentada aquela que lhe é semelhante, a companheira. Do mesmo modo, a referência ao restante da criação, ele se manifesta através da vocação ao cuidado, ao zelo, ou, se quisermos utilizar a linguagem tradicional, ao domínio. Por fim, observamos o ser humano como referido ao próprio Deus, pois, já desde os relatos da tradição Javista, o homem e a mulher passeavam, conviviam com o Criador. Em resumo, uma determinação fundamental do ser humano, que nunca o abandona, é a sua criaturalidade.

Deus não para de agir no mundo e na história, e sua ação criadora não é menos intensa agora no primeiro instante. Deus continua a criar, não somente porque "conserva" o que já fez, como também porque, em sua providência o conduz ao fim a que desde o início o destinou. ${ }^{172}$

\section{2 \\ Ser Vivente}

Toda vida é bela na sua autenticidade, porque viver é conviver. Homo vivens significa dizer que o ser humano é um ser enquanto vive e a vida é a sua característica mais evidente e a mais fundamental. Ela só é possível pela vontade e pelo amor do Deus Criador. Por isso, precisa ser cuidada e vivida de modo apaixonante, empolgante, pois, somente por meio dela, realizam-se obras, objetivos, sonhos, próprios do ser humano como ser vivente; somente por meio dela, se realiza o projeto de salvação para o qual o Deus Criador nos convida, "o Deus criador é o mesmo Deus-Ágape." ${ }^{173}$ Por esta razão, a vida não pode ser fragmentada ou desvalorizada, ao contrário, deve ser cuidada e preservada.

\footnotetext{
${ }^{172}$ SICRE, J. L., Profetismo em Israel: o profeta, os profetas, a mensagem, p.41.

${ }^{173}$ RUBIO, A. G., Unidade na pluralidade: o ser humano à luz da fé e da reflexão cristãs, p.295.
} 
O objetivo do ser humano, a sua grande busca, é pelo sentido da vida, da sua existência, e ele o faz por meio de suas relações com o outro, de sua corporeidade, em uma partilha do sentido comum, que são as experiências vividas, as ações concretizadas e os pensamentos. Esse mesmo ser busca refletir, interpretar e construir sua realidade, por meio da sua história e das histórias das gerações precedentes.

Quando o ser humano se constrói, também constrói o mundo e sua humanidade. Busca a sua essência, a sua interioridade, descobre o amor como razão do seu existir, construindo um mundo pautado em seus ideais. Porém, se foge de sua realidade, de si mesmo, foge também das relações pessoais, se fecha e contribui para a destruição do mundo. O ser humano é, portanto, esse vazio que deve ser preenchido, estando, constantemente, diante da tarefa de sua autorrealização histórica e da abertura à totalidade. Estando em mobilidade, sua busca deve ser pela preservação da vida, pelo encontro construtivo de uma sociedade solidária e sustentável em que seja possível a valorização do humano.

A característica básica do ser humano é justamente a sua capacidade de, em sendo finito, ter abertura para o infinito. Essa mistura de finitude com a infinitude dará a ele completude, fará com que ele se realize, se descubra como um ser finito em busca do infinito, se perceba como pessoa, como criatura cujo horizonte é a aproximação com o Criador. Um ser marcado, pois, pela dinâmica da transcendência. "Pensar o ser humano enquanto pessoa, para Ricoeur, significa precisamente superar todo tipo de antropologia dualista e pensar o ser humano em sua unidade originária." ${ }^{, 174} \mathrm{O}$ seu olhar estará sempre dirigido para o alto e para o futuro.

Homo sapiens significa este ser humano dotado de sabedoria e inteligência, que quer descobrir sempre algo mais, tem capacidade de aprender e conhecer e, por isso, destaca-se das outras criaturas. Segundo Mondin, a sua natureza é de autoconsciência, de um ser encarnado, social, finito, conseguindo fazer uma profunda distinção entre o que é e o que pode ser. É um ser livre, apesar de ser condicionado e limitado, mas capaz de transcender a matéria, o tempo, o espaço. ${ }^{175}$

\footnotetext{
${ }^{174}$ RICOEUR, P. Finitude et culpabilité, I L'homme Faillible. Paris: Aubier, 1960, p.20. (T.N.) ${ }^{175}$ MONDIN, B., O homem, quem é ele? Elementos de Antropologia Filosófica. $12^{\mathrm{a}}$ ed. São Paulo: Paulus, 1997, p.106.
} 
$\mathrm{Na}$ sociedade urbana atual, o conhecimento cada vez mais se torna instrumento de realizações e de poder. Ao mesmo tempo em que promove avanços que apontam para a melhoria da qualidade da vida e ampliação de seu tempo, também têm contribuído para a seleção e exclusão de muitos que não têm as mesmas oportunidades. $\mathrm{O}$ uso do conhecimento nem sempre tem significado sabedoria utilizada na direção da preservação da vida solidária e para avanços no processo de humanização.

Ao lado da compreensão do homo sapiens, temos o Homo volens, que se refere ao ser humano como um ser de vontade, de atitude, de decisão. Ele é um ser dinâmico, que tem a faculdade de decidir se quer ou não algo: se quer ou não estudar, se divertir, amar, tem a liberdade de escolher que atitude tomar diante da beleza e do mistério da vida.

O ser humano de vontades, de decisões, é capaz de escolher a vida ou a morte. Escolhendo a vida, ele irá se apaixonar por ela, lutar por ela e irá em busca de algo mais, de plenitude, sendo capaz de atingir a grande paixão da vida, que é a transcendência; e se escolher a morte, vai negando-se, oprimindo-se, desumanizando-se e coisificando-se.

Homo loquens, outra classificação atribuída, é justamente o poder de fala do ser humano, o que o destaca e diferencia dos outros animais. A fala é estágio mais elaborado dentro do processo de construção da linguagem humana. É por meio da fala que o ser humano se mostra e se define como pessoa, que irá comunicar-se com o outro, relacionar-se e socializar-se. Diante da fala do ser humano, podemos reconhecer quem ele é, suas características e seu modo de pensar, pois a fala, uma das formas de linguagem, revela o que se passa no interior dele. Ela tem a capacidade de unir ou desunir as pessoas, por isso, mais uma vez, a responsabilidade aparece como necessária.

A fala, como uma das formas de linguagem, classifica-se como verbal; além da linguagem verbal, o ser humano, utiliza outras formas de linguagem - as não verbais, como a corporal ou de sinais, dentre outras. Com o avanço das novas tecnologias, na atualidade, ele conquista uma nova possibilidade de comunicação para estabelecer o diálogo com o outro. Muito embora a distância, conserva características da comunicação face a face, mas vem intermediada pela máquina, 
pelas tecnologias digitais. Isto tem modificado o comportamento do ser humano em relação ao outro.

O mundo contemporâneo tem se utilizado, bastante, da fala digital, por meio do mundo eletrônico, das comunidades virtuais, porém, a maneira como utiliza essa fala, mediada pelas tecnologias, deve ser feita com a mesma responsabilidade da linguagem verbal utilizada nas relações pessoais face a face. A fala, em geral, é restritiva a alguém ou a um grupo determinado de pessoas, mas a fala virtual e escrita ultrapassa fronteiras e atinge um número indeterminado de pessoas.

Outro conceito que trazemos é o do Homo socialis - diz respeito à capacidade que o ser humano tem de ser sociável, de viver em comunidade, de ser um ser de relações. A sociabilidade do ser está ligada à capacidade de viver junto com os outros, de dialogar, de participar com o outro suas experiências e suas vontades; é, enfim, aprender a repartir suas emoções, tristezas e felicidades e, também, os seus bens.

Viver em sociedade significa saber compartilhar, dividir, somar sonhos, desejos e realidades. Da capacidade de se socializar com os outros advém a capacidade que o ser humano tem de politicidade, de manter um conjunto de relações com os outros. Esse aspecto é fundamental para a garantia da humanização, fato que ele não alcança sua plenitude no isolamento e, sim, na relação com os outros e com Deus. A humanização é, pois, um processo de desenvolvimento dos seres humanos que ocorre nas inter-relações que eles estabelecem entre si e com a natureza.

A vida urbana atual possibilita grande mobilidade e meios para comunicação, não obstante, as características e os recursos que lhe são próprios e que trazem os indivíduos a uma situação de presença, não garantem, necessariamente, a interação, podendo criar, inclusive, muitas oportunidades de solidão.

O ser humano possui um poder enorme de aprender, de descobrir e de investigar novas criações: o Homo culturalis é justamente este poder, esta dimensão cultural, diz respeito as suas invenções, construções, criação artística, descobertas. A cultura é produto do ser humano e demonstra a agilidade do seu ser, a sua inteligência infinitamente superior a das outras criaturas de Deus, pois pode sempre progredir permanentemente. Pela cultura, mostra-se um ser 
psicofísico, livre, inteligente, histórico e autotranscendente, pois é um ser sempre aberto em busca de algo mais. Destacamos, contudo, que "se for autêntica essa concretização cultural, estará a serviço da humanização do mundo e do crescimento do homem como sujeito, estará a serviço da sua libertação."176

A mobilidade intensa da atualidade, por vias cada vez mais rápidas e complexas, especialmente pelos avanços ocorridos nas tecnologias da informação e comunicação, trouxe o fenômeno da globalização como um forte elemento nos processos de aculturação e desenho de novas identidades. Regras, valores, modos de vida e de trabalho são alguns dos elementos culturais que vêm ganhando novos contornos. Valores próprios de grupos sociais fechados, aos poucos vão sendo colocados à mostra e, especialmente entre os jovens, comparados e questionados, provocando reflexões na direção das mudanças.

Outra dimensão fundamental á dimensão do ser humano é o trabalho é a importância do trabalho - o Homo é faber. Por meio do trabalho ele ganha a vida, aprende a lutar, a conviver, dignifica-se. O trabalho, numa concepção ontológica, faz parte da essência e é exigência para a existência do ser humano. "A natureza do homem é o operador." criativo do indivíduo e se revela sua capacidade transformadora; por meio do ser humano, a natureza se modifica.

O trabalho torna o ser humano um ser sociável, já que demonstra também a dependência recíproca entre ele e o outro. Importante ressaltar que o trabalho evidencia a capacidade de autotranscendência do indivíduo, de superar-se sempre, vencer limites, nunca se satisfazer, por completo, com aquilo que produziu, procurando, continuamente, melhorar suas técnicas. $\mathrm{O}$ ser humano tem a tendência de buscar, incessantemente, o duradouro, o perfeito, o eterno. "É mediante o trabalho que o mundo natural vai sendo humanizado e o ser humano 'vai-se fazendo' nesta tarefa transformadora."178

Homo ludens diz respeito à necessidade de atividade de lazer que o ser humano tem. Ele, quando inventa, se diverte, compete, convive em sociedade distingue-se dos outros animais. No lúdico, o ser humano se realiza, mostra a sua felicidade, sua criatividade, a sua liberdade e se afasta de sua rotina, muitas vezes,

\footnotetext{
${ }^{176}$ MONDIN, B., O homem, quem é ele? Elementos de Antropologia Filosófica, p.400.

${ }^{177}$ Ibid., p.198.

${ }^{178}$ RUBIO, A. G., Unidade na pluralidade: o ser humano à luz da fé e da reflexão cristãs, p.401.
} 
fatigante e opressiva. "O jogo é a antecipação do reino da liberdade e da alegria, da serenidade e da felicidade subjacente aos sonhos de todos os homens."

$\mathrm{Na}$ sociedade urbana atual, o ser humano busca no lazer o prazer pela vida. A corrida, a complexidade do cotidiano na maioria das cidades, a competição e a luta pela preservação da vida têm levado os indivíduos a valorizar os espaços/tempos para o lazer. De acordo com Amado, “[...] são duas as correrias da mentalidade urbana. De um lado, ela corre para ter condições de economicamente participar das ofertas do mercado urbano. De outro, ela corre para aproveitar tudo o que o mercado urbano oferece." 180

Homo religiosus é o aspecto relacionado à religião como manifestação tipicamente humana que acompanha a humanidade, nasce com o ser humano, está em seu presente, passado e futuro. Por ser o ser humano um ser capaz de aprender, sentir e refletir, ele é capaz de, por meio desta reflexão, tomar consciência da existência do Sagrado.

Na religião, mais ainda que em qualquer outra atividade do homem, vem à luz o seu aspecto de autotranscendência: o encontro com o Sagrado é o ato de autotranscendência por excelência; ele ocorre quando o homem transcende o seu ser atual e toda a esfera do real que o circunda. ${ }^{181}$

A liberdade e a autonomia do ser humano só são totalmente alcançadas quando ele consegue se unir ao outro, pois somente por meio dessa comunhão gratuita e lúdica a sua subjetividade pode ser completamente livre, o que significa dizer que o indivíduo só pode ser totalmente humano entre os humanos; o outro faz parte da sua identidade.

A finalidade da vida humana não é uma ação egoísta, a pessoa vive plenamente na medida em que se encontra com o outro, se voltar para ele, como ser dependente dessa relação, capaz de amar, lutar pela vida e construir um mundo melhor. Somente assim, é capaz de amar, sentir, pensar e sonhar.

Esse transcender do eu na direção do outro é o que constitui fundamentalmente a ética. Ela torna-se o eixo fundamental precisamente porque contém e revela a possibilidade e a realidade do além do ser e da identidade do mesmo como transcender para o outro numa relação que Lévinas chama de alteridade. ${ }^{182}$

\footnotetext{
${ }^{179}$ RUBIO, A. G., Unidade na pluralidade: o ser humano à luz da fé e da reflexão cristãs. São Paulo: Loyola, 2001, p.223.

${ }^{180}$ AMADO, J. P., Leituras urbanas da criação. In: MULLER, I. (org.), Perspectivas para uma Nova Teologia da Criação, Petrópolis: Vozes, 2003, p. 239.

${ }^{181}$ Ibid., p.252.

182 OLIVEIRA, M. A., Antropologia Filosófica Contemporânea: subjetividade e inversão teórica. São Paulo: Paulus, 2012, p.238.
} 
Não obstante, este ser humano é um ser autônomo, tem a opção também de escolher pelo fechamento em si mesmo e, por conseguinte, sofrer a infelicidade, o desamor e a destruição.

A dimensão ética se constitui e se materializa nas relações dos seres humanos entre si, com a natureza e com Deus. Vivenciamos em nossos dias contradições de sentidos e do movimento que o ser humano faz em direção ao Criador: ao mesmo tempo em que se ensimesma e acredita na sua autossuficiência, busca relações impessoais e refúgios no sobrenatural, criando deuses e ídolos para afagar a solidão a que se sentenciam e a responder à impotência diante de fugidias e transitórias relações humanas de poder. A religião é chamada a ser caminho para que a criatura se humanize, na medida em que coloca o ser humano numa permanente reflexão que inclui o Criador, os outros seres humanos e a natureza.

As diversas indicações a respeito do ser humano, como, por exemplo, sapiens, volens, loques ou sociais, apontam para a complexidade do conceito vida. Trata-se, como bem sabemos, de um conceito amplo, abrangente, complexo. Nele estão comprometidas estas e outras características do ser humano.

Viver, consequentemente, consiste em permitir que todas estas características se realizem de um modo gradativo e, ainda que em graus distintos de maturação, por igual. Viver não pode se reduzir apenas à dimensão biológica, não consiste apenas no conjunto de movimentos desenvolvidos pelos pulmões, o coração e o cérebro. Muito embora quando deixamos de respirar, ter o sangue circulando em nossos corpos e o cérebro comandando todo este processo, paramos de viver, a vida não se restringe a apenas isso.

Por isso, devemos sempre rejeitar este e todos os outros reducionismos que compreendem o ser humano simplesmente a partir de uma dimensão, sem o devido equilíbrio com as demais. O ser humano é consciência, afeto, vontade, comunicação e muito mais. A grande contribuição que a Antropologia Teológica tem a oferecer, neste ponto, consiste exatamente em mostrar a correlação entre todas estas dimensões. 


\section{3 \\ Capacitado para a Eleição-Aliança}

Eleição e aliança são dois conceitos veterotestamentários que expressam de modo bastante significativo o que significa o ser humano. Estes dois conceitos apontam para a condição relacional do ser humano, condição já tão discutida nos itens anteriores. Pela eleição, o ser humano percebe-se como realidade segunda, pois, em primeiro lugar, vem Aquele que o escolheu. Neste sentido, os conceitos de eleição e criatura se assemelham. A condição humana consiste, pois, em se perceber interpelado a partir de fora, sentir-se amado desde sempre. A primeira atitude não é aquela que brota do ser humano. Quando este age, na verdade, já está ocorrendo o segundo passo, ou seja, a resposta, estabelecendo-se, então, a aliança.

No Antigo Testamento, a revelação de Deus para com a sua criatura é um processo de escolha e aliança. Assim, irá escolher Israel por amor e misericórdia. A aliança com o povo eleito é demonstrada pela presença de Noé e Abraão, momento em que o povo escolhido aceita a salvação divina, submete-se às vontades do Pai e firma um compromisso com Ele. A eleição do ser humano faz com que o mesmo se submeta, por escolha, à vontade e à decisão do Criador, principalmente a de estar com Ele. "Todavia, como único capaz de dialogar e de responder, o homem é chamado também de ser responsável pela natureza, administrador cuidadoso e não dono arbitrário e depredador."183

O ser humano reflete sobre a salvação, sobre as consequências de querer estar nela ou rejeitá-la e percebe que uma vida submetida à vontade do Pai Criador faz com que ele seja responsável e assuma um compromisso com seu Criador. Esta é uma característica da fé Javista: a obediência do ser humano a Deus. É Ele que mostra a sua intenção de diálogo com o ser humano, não o obrigando a nada, mas sinalizando com a sua vontade de libertá-lo e conduzi-lo.

A relação dialógica Criador-criatura situa também o homem de maneira adequada no vasto mundo criado. Uma vez que o ser humano é criatura, não se justifica a arrogância do homem moderno que manipula e destrói criminosamente o mundo criado, dom do amor de Deus. O homem está intimamente vinculado a todas as criaturas, unido a eles numa espécie de "fraternidade" fundamental. ${ }^{184}$

\footnotetext{
${ }^{183}$ RUBIO, A. G., Unidade na pluralidade: o ser humano à luz da fé e da reflexão cristãs, p.297

${ }^{184}$ Ibid., p.297.
} 
A consequência da demonstração de amor e cuidado de Deus para com suas criaturas é revelar o poder de decisão que suas obras possuem, podendo conduzir a sua vida da maneira que quiserem. Essas criaturas são capazes de aceitar ou recusar o compromisso de servir-Lo. Os profetas cada vez mais demonstram a importância da atitude criadora do Senhor, tendo como consequência, a salvação da humanidade. É por isso, que a criação e a salvação devem estar unidas. Esse é o momento escatológico destacado para que toda a humanidade possa estar restabelecida pela ação do Criador que se faz história na história da humanidade.

$\mathrm{Na}$ sociedade urbana atual, apesar dos avanços tecnológicos investidos nas redes de relacionamentos sociais, o isolamento e a solidão coletiva se agravam. Neste ambiente, cresce a dificuldade em assumir alianças na perspectiva da concretização do projeto salvífico, por meio do mandamento maior que é o amor a Deus e ao próximo, pela caridade. Por outro lado, o ser humano de agora, como o de outros tempos, segue sua existência em busca de sua essência e de sua vocação para o Divino. A aliança com Deus por meio de compromissos assumidos com os irmãos é o meio para a preservação do humano nesta era de eletrizante mobilidade, especialmente de valores, sentidos e ideias, alavancada pelas tecnologias da informação e comunicação.

\section{4}

\section{Aberto Positivamente aos Outros}

O ser humano não é um ser somente em si. Pelo contrário, ele só é um ser em sua totalidade quando sai de si. Só a partir do momento em que ele é para o ser e nasce para o ser, torna-se verdadeiramente humano. "O ser é o que marca internamente todas as coisas, é o que dá a cada ente realidade, sentido e nome. ${ }^{, 185}$ A totalidade do ser humano é a direção e o fim de toda a natureza, como também, de toda a realidade. Ele completa o seu ser no amor, a essência do seu bem e a verdade do seu ser. Assim, significa dizer que é um ser transcendental, que ultrapassa o seu ser e se descobre no outro. Deus é quem dá essa possibilidade de abertura para o ser humano chegar ao mais profundo do seu ser, no amor original. No entanto, o ser humano é elevado a ser pessoa enquanto participa da missão universal de Cristo. $\mathrm{O}$ ser pessoal abre-se à dimensão social, em que a

\footnotetext{
${ }^{185}$ OLIVEIRA, M. A., Antropologia Filosófica Contemporânea: Subjetividade e inversão teórica,
} p.47. 
referência ao outro é um elemento tão primário quanto a irrepetibilidade e o autodomínio. $\mathrm{Na}$ abertura ao outro, a pessoa se descobre um ser de diálogo, de relação e de encontro. Esse sair de si para ir em direção ao outro faz parte da constituição dela, sendo uma necessidade. A abertura aos outros constitui, segundo a Antropologia Cristã, o aspecto fundamental da pessoa, pois ela se percebe como um ser capaz de dialogar com outras criaturas e com Deus, através da Revelação.

A relação com Deus, relação única e exclusiva, faz de cada indivíduo humano uma pessoa e não apenas mais um indivíduo da espécie humana. Com Jesus Cristo, a valorização do homem como ser pessoal chega até um ponto inimaginável. É em Jesus Cristo que percebemos como é extraordinária a dignidade de cada ser humano concreto isto é, de cada pessoa. ${ }^{186}$

O ser humano só será capaz de se realizar completamente a partir do momento em que se mostrar um ser capaz de relação consigo mesmo, com o mundo, com o outro e, consequentemente, com Deus, em uma dimensão mais profunda. Só dessa forma, ele irá se descobrir, não somente como natureza, mas como ser. Cada um em sua particularidade e em sua origem contribui para uma unidade entre todos os seres humanos, por serem pertencentes a uma mesma natureza, que é a humana. Cada indivíduo é responsável pela construção da humanidade e da paz e, nessa empreitada, ele não está só, mas tem um Deus que caminha com ele. Como se encontra nos relatos das Sagradas Escrituras, o Deus Criador e Salvador caminha com seu povo. Portanto, o ser humano, a partir da consideração de uma de suas características a da mobilidade urbana atual, é um ser que está em movimento com os outros, conseguindo pouco a pouco refazer, ou não, experiências de liberdade, em que se reconhece no outro.

Por essa razão, podemos dizer que o ser humano é chamado e vocacionado à comunhão de vida com o próprio Deus. Em Jesus Cristo, Filho Unigênito do Pai, mostra-se e revela-se a própria verdade e identidade do ser humano. Em Jesus Cristo aparece a humanidade perfeita. "Toda pessoa é única, mas em relação. E, assim, a dimensão comunitária é constitutiva da pessoa, no extremo oposto a toda afirmação individualista." 187

Com efeito, Adão, o primeiro homem, era figura daquele que haveria de vir, isto é, de Cristo Senhor. Novo Adão, na mesma revelação do mistério do Pai e de seu

\footnotetext{
${ }^{186}$ RUBIO, A. G., Unidade na pluralidade: o ser humano à luz da fé e da reflexão cristãs, p.311.

${ }^{187}$ Ibid., p.316.
} 
amor, Cristo manifesta plenamente o homem ao próprio homem e lhe descobre a sua altíssima vocação. ${ }^{188}$

O crescimento do ser humano em Jesus Cristo leva a todos um crescimento em humanidade. Na inserção do ser humano em Jesus Cristo, pela graça e na sua orientação, por Ele, na criação, o ser humano é levado a compreender e compreender-se como criatura de aliança com o Criador. Seres humanos com aspectos de historicidade, liberdade e corporeidade capazes de Deus, pois são participantes do mistério de Cristo.

Por ter a condição de criatura, o ser humano é capaz de participar com Deus de suas verdades e, na medida em que a sua vontade se direciona a Ele, faz com que essas verdades também estejam inseridas na alma humana. Nos planos do Criador, porém, o ser humano não pode alcançar plenamente o seu destino sem uma comunhão com as demais criaturas; é característica dele precisar de alguém que esteja ao seu lado, que lhe mostre a sua existência.

Cristo veio para fortalecer, plenificar e também corrigir o esforço humano de todas as culturas. Vem ao encontro da busca, da pergunta e da resposta. "Ora para que o ser humano possa viver como gente, como Filho de Deus, como sujeito da história, é necessário que se liberte das correntes que se matem preso num viver de vida sub-humana." 189

Jesus é o Caminho, a Verdade e a Vida (Cf. João 14, 6). Do Antigo ao Novo Testamento há uma coerência profunda da mobilidade e, essencialmente, em torno da imagem do ser humano, como se pode observar nos relatos de Wévin, em seu livro O Homem Bíblico:

Um ser humano aberto ao reconhecimento autêntico da alteridade: a do universo, a do outro, a de Deus e também a sua própria. Um ser humano que, na escola da alteridade, descobre a liberdade que lhe é oferecida e aprende a assumi-la sem transformar numa fortaleza de individualismo e de auto-suficiência, fazendo-a, em vez disso, um lugar de aliança. Um ser humano consciente de que recebeu a vida de um outro o acolhe num espírito de reconhecimento, e abre as mãos e o coração para a justiça, a solidariedade e a partilha. ${ }^{190}$

A liberdade de Deus na criação é verdade fundamental da fé humana. Sua liberdade é a liberdade do amor, que se compromete com o mundo e, sobretudo, com o ser humano. Julga-se assim que a liberdade do ser humano é uma liberdade

\footnotetext{
${ }^{188}$ LADARIA, L. F., Introdução à Antropologia Teológica. São Paulo: Loyola, 1998, p. 27.

${ }^{189}$ RUBIO, A. G., Unidade na pluralidade: o ser humano à luz da fé e da reflexão cristãs, p.74.

${ }^{190}$ WÉNIN, A., O homem bíblico. São Paulo: Loyola, 2006, p.11et. seq.
} 
despertada pela liberdade criativa de Deus. Assim, o ser humano é chamado à responsabilidade na construção do mundo e de cooperar na criação com uma existência autêntica e própria de criatura.

Deus se revela comunhão e não um Deus solitário, e nesta relação chama o ser humano à comunhão. Deus se faz humano em Jesus Cristo, e o ser humano criado, à imagem e semelhança de Deus (Cf. Gs12), é o centro e o ápice de toda a criação, que tem em seu sentido último a salvação em Jesus Cristo. A relação com Deus e a capacidade de conhecê-lo e animá-lo realizam-se com a mediação de Jesus Cristo. A definição de ser humano é dada a partir da encarnação, é cristocêntrica, sendo início e fim do mesmo. "Do ponto de vista neotestamentário, compreende-se perfeitamente que essa unidade é evidente, se levarmos em consideração que todo homem é chamado a participar da ressurreição de Jesus."191

Assim, o ser humano pode julgar, com consciência, que na sociedade urbana atual, em primeiro lugar, vem ele próprio; ele é a novidade sempre atual. "O novo homem e a nova mulher começam a existir no presente. O novo consiste na libertação para viver a liberdade no amor-serviço."192 Seres humanos que, na unidade de uma consciência, de uma liberdade, de um "eu", são espírito e matéria, alma e corpo, transcendência e imanência, abertura para o infinito e o olhar para si; são como criaturas chamadas e criadas no amor de Deus, e salvas pela decisão e resposta no Filho que salva e o humaniza pelo Espírito.

O ser humano possui uma capacidade também criadora, de modificar e transformar o mundo urbano atual, onde consiga conviver e crescer humanamente e hoje é chamado a reinventar-se na sociedade. É a ele inerente uma capacidade dinâmica de existir, com uma inesgotável capacidade de fazer história, porque pensa, decide, comunica, interpreta, comanda e obedece. $\mathrm{O}$ grande brio dele é ter capacidade de transcendência, por isso não pode ser comparado a uma coisa, objeto, nem instrumento.

O ser humano sozinho é incompleto, pois nasce para a sociabilidade, necessita de uma companhia, ou seja, alguém com quem possa compartilhar sentimentos, emoções, preocupações. "É o sentido do outro que constrói o próprio eu. É quando interiorizo o cuidado com o outro, ao ponto de que minha vida

\footnotetext{
${ }^{191}$ LADARIA, L. F., Introdução à Antropologia Teológica, p.65.

${ }^{192}$ RUBIO, A. G., O encontro com Jesus Cristo vivo: um ensaio de cristologia para nossos dias. $14^{\mathrm{a}}$ ed. São Paulo: Paulinas, 2010, p.111.
} 
depende dele/dela, então, posso ser verdadeiramente eu e ser livre."193 Ele é chamado e capacitado por Deus, em caráter de comunhão, para realizar uma cooperação ativa no Reino de Deus. Este chamado fundamental acontece sempre em liberdade e de maneira consciente e toda a ação humana é parte integrante da sua história, que é construída de maneira livre. Ele é ser de decisão e resposta em relação com Deus, com os outros e com o mundo; um ser pessoal e social, que por meio das relações, vem construindo uma identidade e o valor de ser humano.

O ponto de partida deve ser o ser humano, que é se conhece neste ambiente de modernidade atual, chamado à comunhão com Deus, o único a quem o amor criador de Deus se deu, cuja realização começa com a criação e tem, em Cristo, seu ponto culminante, e seu sentido chega a seu cumprimento - ponto central de fé, na esperança da ressurreição em relação a Cristo ressuscitado.

Ora, o Deus da encarnação é o mesmo Deus da criação. A criação já é o começo da salvação. Na criação, encontramos já o movimento kenótico em Deus. Livremente, o Deus criador-salvador faz espaço para a criatura. A criação encontra sua fonte no amor divino, a primeira kénose. Na realidade, pode-se afirmar que a kénose faz parte da realidade de um Deus criador que entrega à liberdade humana a corresponsabilidade pelo mundo criado. Com imenso respeito, próprio do amor, a atuação divina não força, não obriga, não manipula nem instrumentaliza a criação, não a invade dominadoramente. Evidentemente, isso se aplica de modo todo especial ao ser humano, chamado que é a viver a liberdade e a criatividade. ${ }^{194}$

Communio é uma categoria que permite ultrapassar a polarização entre individualismo e coletivismo; o todo (unidade) subsiste nas partes estritamente relacionadas entre si, e as partes (diferenças) se conjugam em um todo. Etimologicamente falando, communio significa "vida em comum", tarefa, serviço, graça, dom. A communio só se realiza na dinâmica da recepção (desde o outro) e da doação (em direção ao outro). Por essa razão, communio não se pode traduzir, suficientemente, por "comunidade” e nem por "participação". Mas está mais perto do termo "comunhão".

Daí podemos concluir que, do ponto de vista salvífico, que é o mais central para a fé cristã, o amor fraterno (que inclui necessariamente o amor a Deus) se reveste de tal importância que todos os demais atos bons, todas as demais expressões cristãs lhe são subordinadas e dele recebem sentido e pertinência. ${ }^{195}$

\footnotetext{
${ }^{193}$ BARROS, M., Dom Helder Câmara: profeta para os nossos dias. São Paulo: Loyola, 2011, p.180.

${ }^{194}$ RUBIO, A. G., A teologia da criação desafiada pela visão evolucionista da vida e do cosmo. In: RUBIO, A. G. (org.) \& AMADO, J. P. (org.), Fé Cristã e pensamento evolucionista: aproximações teológico-pastorais a um tema desafiador. São Paulo: Paulinas, 2012, p.38.

${ }_{195}$ MIRANDA, M. F., A salvação de Jesus Cristo: a doutrina da graça. São Paulo: Loyola, 2004, p.133.
} 
“A genuína comunidade humana é [...] a que existe entre ser humano e ser humano, isto é, aquela comunidade em que o ser humano, pela entrega de si mesmo ao outro, volta-se a si mesmo." ${ }^{196}$ No Novo Testamento, em Paulo, a palavra "communio" (koinonia, em grego) significa "comunidade com alguém" e "participação em algo comum": Todos são membros do "corpo de Cristo", tornam-se um com ele e um com os irmãos e irmãs, membros de seu corpo.

Ainda que eu falasse as línguas dos homens e dos anjos, se não tiver caridade, sou como o bronze que soa, ou como o címbalo que retine" (I Cor. 13, 1). "Nisto temos conhecido o amor: (Jesus) deu sua vida por nós. Também nós outros devemos dar a nossa vida pelos nossos irmãos (I João 3,16 ).

Todo ser humano enfrenta as contradições da vida, que inúmeras vezes são difíceis de suportar. Porém, é possível perceber, que é preferível doar a vida a deixá-la ser arrancada. É possível perceber nessa lei, um apelo a não se poupar, e sim doar a vida aos outros na partilha cotidiana do tempo, das forças e do amor. No convívio com o outro, o ser humano criado como Eu e Tu, sai de seus limites criacionais para se descobrir e conhecer.

É na esperança que se vivencia a solidariedade humana, que se encontra na justiça e na paz, frutos da misericórdia de Deus e alegria de esperanças. O nós começa a ser um nós comunitário no dia em que cada um dos membros descobre cada um dos outros como uma pessoa; começa a tratá-lo como tal e o evoca como tal. Segundo Mounier:

Sem o amor a pessoa não existe [....] sem o amor as pessoas não chegam a se tornar tais. O amor, portanto, não é um atributo do caráter ou uma modalidade de realização, mas a possibilidade de ser: existo somente na medida em que existo para os outros. ${ }^{197}$

Nos dias atuais relata Boff, sobre a importância do cuidado com o outro e do amor, que nasce desse relacionamento. O amor é um fenômeno cósmico e biológico. Ao chegar ao nível humano, ele se revela como a grande força de agregação, de simpatia, de solidariedade. As pessoas se unem e recriam pela linguagem amorosa o sentimento de benquerança e de pertença a um mesmo destino e a uma mesma caminhada histórica. ${ }^{198}$

\footnotetext{
${ }^{196}$ BULTMANN, R., Formen, menschlicher Gemeinschaft. In: MOLTMANN, J., Teologia da Esperança: estudos sobre os fundamentos e as consequências de uma escatologia cristã. $3^{a}$ ed. São Paulo: Loyola, 2005, p.394.

${ }^{197}$ FORTE, B., Um pelo outro: por uma ética da transcendência. São Paulo: Paulinas, 2006, p.396.

${ }^{198}$ BOFF, L., Saber Cuidar: ética do humano, compaixão pela terra. Petrópolis: Vozes, 1999, p.111.
} 
Considerando-se a era moderna, até a primeira metade do séc. XX, tentavase separar a fé da realidade terrena, fazendo com que o cristão vivesse em duas áreas separadas. Era o processo de secularização progressiva da cultura ocidental. Nessa época, o ser humano voltou-se para si mesmo, chegou a acreditar ser um ser supremo. Isso mostra que a falta de Deus torna o ser humano cada vez mais autoritário e egoísta, não existindo mais o outro, o seu próximo, a benquerança.

Como veremos mais adiante, a carência da verdade invade, muitas vezes, esse contexto; o ser humano já não mais a valoriza, já não sente mais a necessidade de buscá-la, o bem maior fica desprezado e o consumismo, o poder, a ganância e a falsidade assumem lugar privilegiado.

Importante destacar a necessidade da alteridade, e ela não existe sem a verdade que, por sua vez, não acontece sem o Cristo - Ele é a Verdade. Só assim é possível superar a crise da solidão. Segundo Forte, não existe uma ética só de intenção, por isso, quando a pessoa decide pela ética da verdade de Deus, sai de si mesmo e age, vai ao encontro de seu próximo. Cristo não ensina nenhuma ética abstrata, a ser praticada a qualquer custo. $\mathrm{O}$ ser humano verdadeiro recebe a forma de Cristo, assim, afastado de uma ética abstrata e orientado para uma ética concreta. $^{199}$

No momento em que o cristão deixa de lado o abstrato, a mera intenção e vai ao encontro do outro, surge a responsabilidade e a autêntica ética. E quando se vai ao encontro do outro com responsabilidade, passa-se a se querer o bem do próximo, a importar-se com ele, a valorizá-lo, a sofrer com e por ele, e é dessa forma que surge o amor, que é sempre revelação de Deus.

É preciso ter consciência da verdade, encarar a realidade como, de fato, ela é. Essa consciência deve vir antes da ética, da ação e do amor, pois a supremacia é da verdade. Sendo o ser humano responsável com o bem, irá ser também com a verdade e com o próximo. Caso contrário, com a negação de bem, o mal irá aparecer.

A co-humanidade constitui um aspecto fundamental da abertura ou transcendência própria da pessoa. [...]. Na relação com Deus, o ser humano é revelado como um ser de diálogo, de decisão e da resposta. Esta relação dialógica com Deus é fundamento de abertura ao diálogo e da resposta em face da interpelação dos outros seres humanos. A revelação do Deus trino ressalta de maneira ainda mais profunda até que ponto a relação é constitutiva do ser humano. Criado à imagem de um Deus solidário, a real humanização passa pelo desenvolvimento da relação pessoal

\footnotetext{
${ }^{199}$ BOFF, L., Saber Cuidar: ética do humano, compaixão pela terra, p.118 et. seq.
} 
(Deus, outros seres humanos). Em Jesus Cristo, modelo e cabeça da nova humanidade, a relação com os irmãos é vivida no amor-serviço solidário. ${ }^{200}$

O ser humano deve se dirigir livremente para o bem, pois o bem não obriga, não oprime, ele é verdadeiramente libertador. Ele faz do indivíduo um ser digno, com vontades e atitudes que libertam e que ajudam o outro a crescer e a caminhar. Não é apenas o agir individualizado do ser humano que o torna responsável, mas também o ir ao encontro do outro, ao encontro do diferente. Com isso, ele busca a sua identidade, que só volta para si depois de ir ao outro e por isso, a obra de Deus só é capaz de viver, verdadeiramente, o amor, a ética e a fé cristã se em comunidade, em relação ao próximo. Ninguém vive para si mesmo.

Logo o amor autêntico a Deus nasce, vive, cresce e se comprova a partir de opções concretas, em geral atos das virtudes: paciência, temperança, desapego, piedade, humildade, perseverança, justiça etc. Tais virtudes devem sua existência ao estímulo superior do amor, que não é assim mais uma virtude, mas a fonte delas. ${ }^{201}$

A necessidade natural do ser humano de estar com o outro é condição de sua humanidade já que o homem é o ser da aprendizagem. É com o outro ou com os outros que ele aprende e desenvolve sua humanidade e nesse processo natural, ele cria redes de relações. Essas relações se dão inicialmente no ambiente primeiro familiar mais próximo e vai se expandindo nas outras relações que constrói em sua vivência e amadurecimento social. Também nesta sociedade de mobilidade por meio de mecanismos diversos, o homem, naturalmente busca a companhia dos seus semelhantes. Mesmo só, ele amplia sua rede de relações, de encontros e de trocas através, por exemplo, das redes sociais virtuais de relacionamento. A atual mobilidade física coloca homens e mulheres lado a lado, porém nem sempre numa interação que permita formar comunidades. Por sua vez, a mobilidade mediada pelas tecnologias da informação e comunicação, insere os indivíduos em comunidades de relacionamento por meio da qual passa a fazer parte de grupos globalizados.

\section{5}

\section{Aberto ao Divino e Absoluto}

A partir do momento em que o ser humano se descobre ilimitado, necessitado do outro e, capaz de abrir-se ao outro, mostra-se um ser capaz de

\footnotetext{
${ }^{200}$ RUBIO, A. G., Unidade na pluralidade: o ser humano à luz da fé e da reflexão cristãs, p.458.

${ }^{201}$ MIRANDA, M. F., A salvação de Jesus Cristo: a doutrina da graça, p.131.
} 
comunhão, um ser capaz de abertura para o infinito e, portanto, um ser também capaz de Deus e necessitado de Deus. Diante de tal descoberta, consegue alcançar a sua verdadeira essência, mediante a sua existência. Isso é o que constitui o ser humano espiritual, que só é capaz de se compreender corretamente enquanto correlação ao ser em seu todo.

Por esta razão, o ser humano, no momento em que se descobre um ser espiritual, aberto para o Transcendente, torna-se mais próximo do próximo, mais verdadeiro, mais compreensivo, mais ético, mais livre e mais humano. Enfim, a liberdade humana é resultado da buscada e conquistada, em um processo contínuo, durante a vida humana corpórea, e essa liberdade é uma decisão expressada em nosso dia a dia, por meio de nossas atitudes. "Assim, a decisão por um sentido fundamental, a decisão por seu próprio ser, significa também uma decisão pelo mundo, por uma configuração específica da ordem do todo do ser." 202

O ser humano concreto é um nó de relações voltado para todas as direções até para o Infinito. Ele é, na verdade, um espírito-no-mundo, mas o mundo não esgota as capacidades que tem o ser de conhecer, querer, sentir e amar. Nenhum ato concreto esgota totalmente o dinamismo do querer, pois há dentro do homem uma disponibilidade ilimitada de sentir, onde só o amor eterno é descanso do coração humano.

Como apresentado anteriormente, o ser humano não está só, existe Deus que o procura. É no interior do horizonte que se insere a reflexão original de Heschel sobre o ser humano como preocupação de Deus. "O objetivo da teologia é certamente Deus, e é de Deus que a teologia fala ao se referir ao ser humano tal como ele se encontra diante de Deus, a saber, do ponto de vista da fé."203

$\mathrm{O}$ ser humano busca o absoluto. A raiz bíblica mostra como a experiência desse absoluto acontece no cotidiano humano, considerado em toda a sua integralidade. Onde ele estiver, ali estará Deus, pois a criatura é um ser de caminho, de busca, de esperança. Não é possível encontrar criatura alguma que não tenha uma busca, enfim, um movimento para a realização. Para o ser humano, o fundamento de sua existência está no Deus Criador, pois é Ele quem alimenta a

${ }^{202}$ OLIVEIRA, M. A., Antropologia Filosófica Contemporânea: subjetividade e inversão teórica. São Paulo: Paulus, 2012, p.270.

${ }^{203}$ MOLTMANN, J., Teologia da Esperança: estudos sobre os fundamentos e as consequências de uma escatologia cristã, p.83. 
esperança do caminhar de toda a humanidade; ele é mediado pela graça de Jesus Cristo, e esta graça que está no início da caminhada humana, irá acompanhá-lo e conduzi-lo sempre à plenitude sonhada por Deus já antes da criação.

Em Deus há um único querer, que se identifica com seu próprio ser infinito. Esse único querer diz respeito a encarnação do Verbo, pois esta pressupõe sem mais a criação. Podemos mesmo dizer que a encarnação é uma modalidade mais radical da criação. Querendo sair de si para se comunicar a si próprio (encarnação), Deus cria para que esta autocomunicação divina tenha um destinatário. Nesse sentido, aparece Jesus Cristo como sentido último do universo, da humanidade, da história. Deus cria para comunicar para fora de si a existência trinitária. ${ }^{204}$

\section{6 \\ Pessoa}

Não ser algo, mas ser alguém. Não se pergunta apenas o que é, mas, sobretudo quem é. O ser humano pessoa, diz-se sujeito, senhor de si mesmo e, portanto, capaz de formar ser de modo criativo.

Nos espaços urbanos atuais, percebe-se uma mudança entre os espaços socialmente configurados, como, por exemplo, a moradia, o trabalho, convivência, religiosidade e os espaços fisicamente estabelecidos que se tornam diferentes pelo processo de mobilidade, causando um desenraizamento, um movimento constante, uma nova experiência bíblica exodal do ser humano como pessoa, na busca de inserção no campo, no clã, na tribo.

O ser humano vive em uma situação completamente paradoxal; é pessoa consciente, independente e livre, com capacidade de planejar, modificar e transformar a sociedade em que vive. Ser com uma capacidade inata de pensar decidir e criar, que não só tem consciência, como também é pela consciência que ele se define. A consciência faz com que ele se reconheça como pessoa e colabore no processo de humanização.

Pensar o ser humano como pessoa seria o mesmo que pensar em sua existência, em sua origem, em seu ser como indivíduo, que tem como característica ser imagem e semelhança de Deus. "O reconhecimento do ser pessoa está ligado ao seu ser, e não ao seu agir. "205

Apesar da raiz do conceito de pessoa ter sua origem na palavra grega prósôpon, ele não se desenvolveu entre os gregos, pois para eles o que definia o

\footnotetext{
${ }^{204}$ MIRANDA, M. F., A salvação de Jesus Cristo: a doutrina da graça, p.43.

${ }^{205}$ GALANTINO, N., Dizer homem hoje: novos caminhos da antropologia filosófica. São Paulo: Paulus, 2003, p.125.
} 
ser humano era ser espírito. O corpo humano era apenas a maneira como o espírito tinha para se manifestar, formando o dualismo corpo-espírito. O espírito do ser humano era aprisionado em seu corpo e se expressava através dele, fazendo dele um indivíduo. O corpo significava uma decadência para o espírito.

O conceito de pessoa veio a se desenvolver realmente com o cristianismo, momento em que foi ressaltada a capacidade do ser humano de se relacionar com Deus, por meio do diálogo. Ele foi traduzido para o latim, fazendo com que fosse construído e ganhasse evidência na antropologia. Traduziu-se a palavra grega prósôpon para a palavra latina persona, que pertencia ao direito romano, mas que nesse momento foi ampliada para dirigir-se a todo ser humano.

As definições e as características do que seja pessoa feitas quer pela patrística quer pela teologia medieval focalizam aspectos básicos da realidade da pessoa, a saber: $1^{\circ}$ a "intensidade", quer dizer a pessoa é independente [...]; $2^{\circ}$ o caráter único e irrepetível de cada pessoa singular [...]; $3^{\circ}$ pela sua natureza espiritual a pessoa não fica fechada em si própria, antes está aberta a realidade toda, ao horizonte ilimitado do ser. ${ }^{206}$

Devemos observar que o que realmente caracteriza o ser humano é a sua condição de pessoa e a sua natureza humana. Quanto mais humano o ser é, mais ele se aproxima da sua essência de pessoa.

A pessoa tem em si mesma a sua própria finalidade. No seu agir, a pessoa, acima de tudo, se auto-realiza como ser pessoal. Por isso, a pessoa não deve ser medida com critérios meramente utilitários. Consequência: a pessoa não é um objeto ou um instrumento para ser usado e depois deixado de lado. ${ }^{207}$

A vocação de ser pessoa é concedida somente ao ser humano. Por isso ele é um ser complexo, sempre em busca de algo mais, capaz de se relacionar com os outros, dependente da vida social, para conseguir atingir o seu próprio objetivo de humanidade. Existem duas dimensões que expressam as características básicas da pessoa, a sua especificidade: a dimensão de interiorização e a de transcendência.

A dimensão da interiorização ou imanência acontece quando a pessoa está centrada em si mesma, busca o seu íntimo, a sua interioridade e, assim, se percebe autônoma, única, independente, não sendo propriedade do outro. Nessa dimensão, a pessoa também irá sentir-se responsável pelos seus atos e escolhas, pois toma consciência que somente ela tem a capacidade de dirigir a sua vida e escolher seus valores e princípios. Na medida em que ela tem a liberdade de decidir, nasce a

\footnotetext{
${ }^{206}$ RUBIO, A. G., Unidade na pluralidade: o ser humano à luz da fé e da reflexão cristãs. São Paulo: Loyola, 2001, p.307.

${ }^{207}$ Ibid., p.308.
} 
responsabilidade de assumir suas consequências. É por isso que toda espécie de manipulação da vida humana fere a dignidade da pessoa. "Esta atitude de transformação responsável faz contraste com a atitude de contemplação e com a sensibilidade para perceber no mundo criado sinais da presença e da atuação do Deus criador." 208

Já na dimensão da transcendência, a pessoa se descobre como um ser de abertura para os outros e para o outro, pois só assim é capaz de se realizar. Quando ela se abre para o mundo, percebe que faz parte do mundo natural, como criatura em meio a outras criaturas e, por isso, quando luta para transformar o mundo para si, também o faz para os outros. Ela tem o dever de construir uma vida digna para todos, vivendo a solidariedade e a responsabilidade perante as demais criaturas.

\begin{abstract}
A moderna sociedade se compreende como uma sociedade emancipada, capaz de caminhar através da história sem nenhum tipo de tutela religiosa, adulta, maior de idade. A salvação cristã deve, de um lado, respeitar esta justa autonomia humana, oferecendo-lhe espaço para sua atuação e criatividade, mas, de outro, se comprovar como a realização desta mesma autonomia, e não como a ela se contrapondo. Qualquer representação de um Deus que olhasse as realizações humanas como suas concorrentes ou rivais deveria ser corrigida para fazer jus ao que nos testemunha a Escritura. ${ }^{209}$
\end{abstract}

Nos ambientes de mobilidade urbana atual, em meio a tantas descobertas e novidades, frutos do desenvolvimento tecnológico, a pessoa corre o risco de se esquecer de sua natureza e se fechar, tornando-se um ser individualista, que se basta. A exclusão de tantos, os quais não têm acesso às benesses dos avanços científicos e tecnológicos se dá também na sua desvalorização tendo como parâmetro seu poder consumidor e produtor. Essa mobilidade em que as pessoas ficam sós, ainda que lado a lado, movidas pela corrida imposta pelos atuais modelos de trabalho e produção e a necessidade induzida de consumo assevera o anonimato e a desvalorização da pessoa em sua individualidade.

$\mathrm{Na}$ atualidade, segundo a lógica do mercado globalizado, a pessoa vai se coisificando, transformando-se em um objeto de mercado, que pode ser usado, manipulado e até vendido. A pessoa é visualizada como se estivesse em uma vitrine, podendo ser trocada e experimentada, estimulando a competitividade pelo melhor e mais visível dentro da sociedade.

\footnotetext{
${ }^{208}$ RUBIO, A. G., Unidade na pluralidade: o ser humano à luz da fé e da reflexão cristãs, p.310.

${ }^{209}$ MIRANDA, M. F., A salvação de Jesus Cristo, p.27.
} 
O que se percebe, paralelamente, é justamente a vontade de encontrar um sentido para a vida, de encontrar algo que preencha o grande vazio existencial humano, fazendo com que a pessoa direcione essa vontade para outros caminhos apresentados pela modernidade, como o consumismo, o relacionamento virtual desenfreado, a competitividade, a vaidade, etc.

Porém, cada vez que o ser humano toma um desses caminhos, tentando encontrar o sentido para a sua existência, frustra-se, pois em nenhum deles achará o que procura. Essa frustração, contudo, poderá fazer com que ele se volte para si mesmo, em uma atitude verdadeira e reflexiva e, por meio da graça, se abra para as verdadeiras relações com os outros, alcançando, por conseguinte, o Outro que é Deus. Pode-se dizer que a pessoa precisa tomar consciência da sua identidade e da sua dignidade.

Por isso, a defesa da dignidade da pessoa humana comporta o compromisso, no interior das tensões e conflitos próprios a cada situação, contra a injustiça, a opressão, a miséria etc, que impedem os seres humanos concretos de desenvolverem sua riqueza pessoal. Comporta, sem dúvida, o compromisso com as pessoas que têm a sua dignidade aviltada, mas implica igualmente o compromisso em nível estrutural de tornar possível [...] uma sociedade qualitativamente diferente, dotada de estruturas a serviço da possibilidade de personalização para todos. ${ }^{210}$

\section{7 \\ Ser que é Corpo}

A respeito da pergunta o que é o ser humano e suas possíveis definições, optamos por destacar alguns aspectos dentre tantos que buscam traduzir esse ser de essência e existência, de produção e consumo, de movimento e busca, assim criado por Deus, que imprime em sua criação o livre arbítrio, ao mesmo tempo em que convida e apresenta um projeto de humanização.

Nesse sentido, faz-se necessária uma reflexão sobre o aspecto que lhe dá materialidade e concretude, no sentido de que o homem é um ser corporal. "A corporeidade é uma dimensão da pessoa humana, do 'eu' humano"211 e, assim, embora façamos alusão aos termos gerais, o fazemos apenas com o intuito de auxiliar na compreensão básica destes. Sem pretender restringir, no entanto, a reflexão do termo geral, buscaremos ampliá-lo a partir das contribuições da antropologia teológica que direciona o estudo proposto. Assim, ao tratarmos do

\footnotetext{
${ }^{210}$ RUBIO, A. G., Unidade na pluralidade: o ser humano à luz da fé e da reflexão cristãs, p.316.

${ }^{211}$ Ibid., p.345.
} 
aspecto corpóreo, nós o fazemos buscando sua relação com o termo homo somaticus que foi utilizado no período de São Paulo e Filão de Alexandria, servindo para diferenciar no homem dois elementos, o psíquico e o somático, que significavam a alma e o corpo. Hoje, são utilizados os termos homo sapiens, homo vivens, homo religiosus, demonstrando as dimensões do ser humano como um ser de vida, de conhecimento e de religiosidade. ${ }^{212}$ Mas, para identificar a dimensão corpórea do homem, se utiliza a expressão homo somaticus.

É exatamente através da corporeidade que o ser humano manifesta sua indispensável condição relacional. É através do corpo que ele, por exemplo, olha e contempla, escuta, abraça, envolve-se. É também através do corpo que o ser humano, quando se fecha ao relacionamento, luta, rejeita e até mesmo destrói. Neste sentido, podemos entender o que significa dizer que o ser humano não apenas possui um corpo. Na verdade, ele é um corpo.

Ao olhar a realidade atual, verificamos duas características que necessitam ser incessantemente aprofundadas, ainda que se possa ter a impressão de estar repetindo. A primeira destas características diz respeito à inversão do dualismo. $\mathrm{Se}$, em outras épocas, marcadas bem mais pela estabilidade, a relação corpo e alma tinha seu peso colocado sobre a alma, o atual momento, individualizante, consumista, tende a colocar o peso sobre o corpo, nele buscando, de modo excludente em relação a outras dimensões, o sentido da existência.

Na medida, porém, que o corpo, sozinho, não possui condições de fornecer a totalidade do sentido, estabelece-se uma espécie de crise, em que o ser humano, concebido prioritária e excludentemente como um ser corporal, acaba por navegar num horizonte dos sentidos parciais, momentâneos, imediatos, passageiros. Esta é a segunda das características da corporeidade numa dimensão como a atual.

O corpo é dotado de funções, de mecanismos, de vida, de desenvolvimento. O ser humano tem o poder de dominar o seu corpo e, é por meio desse corpo, que terá a capacidade de subjugar o mundo e transformá-lo. O corpo é elemento essencial do ser humano, responsável pela sua capacidade funcional. Sobre ele, o ser humano exercita sua liberdade e decide sobre como se movimentar no mundo, por meio da capacidade de dimensionar espaços/tempos seus e do outro que vive no mesmo lugar. Só através do seu corpo o indivíduo é capaz de expressar a sua

${ }^{212}$ MONDIN, B., O homem, quem é ele? Elementos de Antropologia Filosófica. $12^{\mathrm{a}}$ ed. São Paulo: Paulus, 1997, p.57. 
vida, o seu estar no mundo. Somente por meio dele pode se nutrir, reproduzir, divertir, comunicar e aprender. Ele é um instrumento pelo qual a existência humana é provada, manifestada e visualizada.

O meu corpo é o lugar privilegiado no qual o mundo se divide, recebe múltiplos significados e torna-se o universo humano. Mas ao mesmo tempo que decompõe o universo, o meu corpo não pára de o reunir, em ato simples, inseparável do seu ser; ele junta e recompõe incessantemente em si mesmo o que constantemente se divide, reagrupa em uma única harmonia e os significados diferentes nos quais divide o mundo. [...] O meu corpo determina o centro do universo; é o ponto indivisível no qual se opera a análise e a síntese de tudo. ${ }^{213}$

Por meio de um corpo que o ser humano consegue expressar suas emoções, sentimentos, pensamentos e agir com responsabilidade. Através do corpo que é possível à pessoa vivenciar a sua limitação, reconhecer as suas fraquezas e a sua dependência do outro. Somente pelo corpo que o ser humano consegue ir ao encontro do outro e é por meio dele que a pessoa conseguirá se abrir para a alteridade e para o diferente. ${ }^{214}$

Verifica-se que a identificação de uma virtude ou a prática de um vício só pode ser manifestada e concretizada pela existência de um corpo. São Tomás de Aquino irá refletir sobre a existência do corpo da seguinte maneira:

O homem é o ser que realiza operações do homem. Mas nós demonstramos que o sentir não é operação efetuada apenas pela alma. Sendo, pois, o sentir operação do homem, se bem que não seja a sua operação própria e específica, é claro que o homem não é apenas alma, mas conjunto, que resulta composto por alma e corpo. $^{215}$

Esse é o ser perfeito, gerado para a positividade, é a "perfeição de todas as perfeições". O corpo do ser humano é condição de possibilidade tanto da consciência e da autoconsciência como da intersubjetividade, enquanto características específicas desse ser.

A capacidade do ser humano de refletir expressamente sobre si mesmo, sobre as coisas, é possibilitada por uma unidade originária do ser humano com o ser: o ser humano só é a partir de algo mais originário, que o deixa ser ele mesmo de tal modo que o ser humano só é para si, presente a si, porque, enquanto espírito, é a partir do ser e tem no ser o seu centro, o que já se revela na infância. É precisamente a vivência dessa totalidade que faz da criança um lugar excelente para o pensamento. ${ }^{216}$

\footnotetext{
${ }^{213}$ BARBOTIN, E., Humanité de l'homme. Strasbourg: Aubier, 1970, p.35. (T.N.)

${ }^{214}$ LADARIA, L. F., Introdução à Antropologia Teológica. São Paulo: Loyola, 1998, p.54.

${ }^{215}$ AQUINO, T., Summa Theologiae, I, q. 75, a. 4.

${ }^{216}$ OLIVEIRA, M. A., Antropologia Filosófica Contemporânea: subjetividade e inversão teórica, p.38.
} 
O corpo humano demonstra muito claramente o estado de perecividade, de limite, do homo somaticus, não só pela necessidade que ele tem de se alimentar, de ser protegido e defendido, mas também pela sua própria estrutura. Porém, esse limite do ser humano não é a última palavra da sua somaticidade. Essa dependência do ser traz também um contraste com a sua própria natureza, que também é de abertura, que busca uma felicidade mais completa. É uma somaticidade que transcende à própria natureza humana, transformando-se em uma verdadeira epifania do espírito.

O ser humano, enquanto ser corporal-orgânico-espiritual, só torna-se completo quando esses três aspectos se encontram, ou seja, somente quando os mundos objetivo, subjetivo e intersubjetivo se completam e se interpenetram. Ele é um ser complexo e de relação, um ser orgânico, corpóreo, com sua origem no mundo, integrado a ele, tendo o seu corpo como um objeto de comunicação com o exterior, que é atingível como outros objetos.

O corpo humano é, pois, a parte orgânica do sujeito no mundo, que lhe permite nele intervir e transformá-lo. Sendo assim, o ser humano experimenta a sua transcendência sobre a natureza e, no mesmo instante, tem que reconhecer a sua dependência dela para a satisfação de suas necessidades pessoais. A corporeidade do ser humano permite que ele se relacione com os outros no mundo. Como afirma Oliveira: “A corporeidade é o próprio homem e, ao mesmo tempo, é, justamente, o homem no seu envolvimento no mundo da alteridade e, portanto, também no mundo do não sujeito, no mundo da natureza."217

O corpo é, pois, parte fundamental do ser humano. Por meio dele, é que o ser vai se abrir para a alteridade e para o diferente e, assim, com a consciência da limitação do seu corpo, irá tentar alcançar o ilimitado pela transcendência, o que não se define somente enquanto realidade no que de fato ele é, mas pela capacidade de transcender a essa realidade.

O ser humano emerge, então, como o ser de abertura ao ser em seu todo, como o ser da totalidade, que encerra simplesmente tudo, o que implica negação de qualquer limite e exterioridade: o ser da subjetividade se revela coextensivo com o ser em seu todo, inserido no todo, determinado pelo todo, mas em princípio aberto a esse todo por ser a instância que expressa o todo. ${ }^{218}$

\footnotetext{
${ }^{217}$ OLIVEIRA, M. A., Filosofia Transcendental e Religião: Ensaio sobre a Filosofia da Religião em Karl Rahner. São Paulo: Loyola, 1984, p.235.

${ }^{218}$ Id., Antropologia Filosófica Contemporânea: subjetividade e inversão teórica, p.184.
} 
Nesse sentido, a dimensão corpórea do ser humano guarda em si e torna visível a necessidade das inter-relações que ele precisa estabelecer com o ambiente natural, social e espiritual como condição para a vida.

Porém, na sociedade urbana atual, a preocupação com o corpo cresceu, assumindo lugar absoluto nas preocupações, sentidos e cuidados por aquilo que ele passa a representar: autoafirmação, aceitação social, exigências e até mesmo passaporte para ingresso e permanência na vida urbana moderna que valoriza a imagem. O cuidado com o corpo, cada vez mais, ganha evidência na sociedade urbana atual. Esse cuidado também inclui, de acordo com Amado, “[...] o contato com a natureza como um dos aspectos mais buscados com vistas à preservação da qualidade de vida e tal contato está diretamente ligado tanto à preservação do corpo físico quanto ao equilíbrio emocional" ${ }^{\text {219 }}$. Nesse contexto, segundo o autor, o corpo ganha dimensões para o indivíduo e para a sociedade de tal vulto que passa a permear as questões que dizem respeito ao "sentido da vida".

A preocupação do ser humano com o seu corpo ganha dimensões decisivas e inquietantes, já que ele se vê diante do grande desafio de buscar formas de lidar com a perecividade, ou seja, com o envelhecimento e os desgastes naturais do tempo. Essas preocupações têm imposto, também, à ciência a busca de recursos científicos e tecnológicos para retardar os efeitos indesejáveis e ampliar a durabilidade e a aparência exigidas nos tempos atuais. Segundo Amado, “[...] em meio a toda a pluralidade de ofertas para o corpo, este perdeu o seu significado, o seu sentido e o fenômeno mais contundente a comprovar esta afirmação está na perene necessidade de mudança que o corpo enfrenta" 220 .

O corpo precisa ser cuidado e o ser humano é responsável por ele dado que por meio dele a vida se sustenta e se revela. No entanto, o princípio de que o corpo é templo do Espírito Santo, pode perder força diante do sentido a ele atribuído na sociedade de valorização da aparência e da vitalidade (no sentido da saúde necessária ao trabalho e à vida social). O cuidado com o corpo e a mensagem que ele por si transmite tornam-se as mais importantes referências e possuem maior poderio do que as ideias, a razão e o espírito. O corpo é parte de valor inquestionável do ser humano, criatura de Deus que, ao criá-lo, deu-lhe a

\footnotetext{
${ }^{219}$ AMADO, J. P., Leituras urbanas da criação. In: MULLER, I. (org.), Perspectivas para uma Nova Teologia da Criação. Petrópolis: Vozes, 2003, p.233 et. seq.

${ }^{220}$ Ibid., p.235.
} 
necessária materialidade, singularidade, sensibilidade e transitoriedade, o que lhe permite concretizar sua humanidade na sua relação consigo e com os outros.

\section{8}

\section{Aberto ao Futuro}

Dentro de cada um mora o homo absconditus do futuro. Este ser humano, na sua relação com o futuro, se traduz como aquele que está sempre na espera; está ainda nascendo; tudo é sempre promessa; o ponto de chegada é de novo o ponto de partida.

O ser humano concreto, revelado pela missão cristã, em confronto com outras definições universais de ser humano na antropologia filosófica, deve por isto também esboçar, a partir de si mesmo, estruturas universais do ser humano, em que já agora brilhe o futuro da fé como o futuro de toda a humanidade. ${ }^{221}$

A futuridade do ser humano é uma característica nem sempre muito aprofundada. Os motivos para este fato são vários. Destaca-se, no entanto, para efeitos desta dissertação, o fato de que a regra para a existência é o estático. Assim, o futuro tende a ser visto como degradação e, por consequência, como negatividade. A própria reflexão cristã tendeu a colocar o futuro apenas no além da história, deixando à escatologia os aspectos post-mortem.

Quando, no entanto, nos deparamos como uma realidade fortemente imanentizadora como a atual, em que a mobilidade acaba por dar sentido a tudo que nos cerca, o futuro se torna também uma questão intra-histórica. Não se trata, deste modo, de se reverter o dualismo, o que ocorreria se abandonássemos a preocupação pelo transistórico, fixando-nos somente no histórico.

O ser humano é, de fato, um ser de futuro, primeiro, no sentido de que, para ele, criatura corporal, eleita e responsável, ele nunca está plenamente satisfeito com o presente. É, neste sentido, um ser inquieto, desejoso de ter, condição mais imediata, e ser, condição plana, sempre mais. Esta abertura para o futuro, abertura que já se concretiza nas insatisfações diante do agora, o colocam em condição de contínua, de perene abertura para o novo, o que, se por um lado o assusta, por outro, o atrai. "Em todo esse processo, emerge uma compreensão de ser humano,

\footnotetext{
${ }^{221}$ MOLTMANN, J., Teologia da Esperança: estudos sobre os fundamentos e as consequências de
} uma escatologia cristã. $3^{\text {a }}$ ed. São Paulo: Loyola, 2005, p.359. 
sempre chamado a articular liberdade com ação divina, num contínuo acolher o passado, reconhecer o presente e se abrir ao futuro."222

Por ser o humano um ser histórico e constituído de uma identidade caracterizada pela razão e liberdade, é, também, um espírito na matéria, e esta é a porta de entrada para tudo o que conhece e quer, mas também é limitante. Essa identidade restritiva conduz ao sentido de que o ser humano não se basta a si mesmo, busca algo além de si.

O homem é um ser temporal-histórico. Temporal, porque referido a um passado e a um futuro, visto sempre a partir do presente. Histórico, porque tem consciência de que o passado (começo) e o futuro (finalidade) influenciam poderosamente o presente, oferecendo-lhe significação e fundamentando o conteúdo e a orientação do agir e mesmo da existência. ${ }^{223}$

A revelação se dá na história, que é vida vivida e refletida. O ser humano não é só passado e presente, é, principalmente, futuro, projeto, prospecção, distensão para o amanhã. $\mathrm{Na}$ relação com o infinito, ele encontra a sua consistência, conhece-se, relaciona-se com os outros e se convence de que não habita um tempo/espaço pelo acaso, mas foi posto ali: confia-se. Está, pois, incluída na questão da identidade do ser humano a relação com Deus. Como criatura de Deus, ele é por essência um ente de liberdade que se fortalece com a verdade e que caminha na direção do Criador.

$\mathrm{Na}$ sociedade urbana e pós-moderna, observa-se que presente e futuro se interpenetram e o ser humano desse tempo não espera, dado que a velocidade com que a realidade se altera, resulta na dificuldade de se antecipar às transformações. Por outro lado, a relação com o futuro, no sentido da perspectiva da esperança pelo desenvolvimento do próprio ser humano e seu ambiente é sustento em sua existência.

As principais afirmações acerca do ser humano à luz da Antropologia Cristã nos revelam um ser de futuro, de movimento na busca da Verdade.

\section{9}

\section{Em Busca da Verdade}

A busca da verdade sempre oscilou entre dois polos. De um lado, deparamo-nos com a verdade objetiva, dado concreto, anterior a cada ser humano

\footnotetext{
222 RUBIO, A. G. \& AMADO, J. P., Fé Cristã e pensamento evolucionista: aproximações teológico-pastorais a um tema desafiador. São Paulo: Paulinas, 2012, p.12.

${ }^{223}$ RUBIO, A. G., Unidade na pluralidade: o ser humano à luz da fé e da reflexão cristãs, p.437.
} 
e a todos os seres humanos. A experiência cristã sempre contemplou a verdade como algo a acolher, como o próprio Deus. Assim, por exemplo, Jesus se definiu: caminho, verdade e vida (Cf. Jo 14, 6). Da liberdade de consciência decorre o dever de procurar a verdade. E é assim que nasce a responsabilidade moral. Porém, onde essa verdade não puder ser revelada no seu todo, deve-se procurar seguir a opinião mais coerente ou a mais próxima da verdade, pois a partir do momento em que o ser humano vai amadurecendo na razão, vai também crescendo sua responsabilidade moral, diante da lei, da verdade e do outro.

De outro lado, encontramos o ser humano, com suas histórias, cada uma tão peculiar, fazendo com que as individualidades participem do processo de busca e encontro da verdade por meio de modos distintos.

Antropologicamente, o grande problema reside - também aqui! - no dualismo, que tende a restringir a busca e o encontro da verdade a um dos polos. Num contexto de forte sedentarismo, o polo predominante é, sem dúvida, o da objetividade; num contexto de forte mobilidade, o polo predominante é o da subjetividade. Ainda sob o prisma antropológico, sabemos que nenhum dos dois polos, isoladamente, resolve a questão da busca e do encontro da verdade.

O ser humano é livre para escolher entre amar a verdade ou recusá-la, conduzindo-se entre o ato bom e o ato mau, ele também tem a liberdade de escolher sair de si mesmo para ir ao encontro do Outro e dos outros ou fechar-se em seu egoísmo e solidão. "O amor - no qual se exprime o reconhecimento da verdade do ser e o ato de gratidão com que corresponde a ela - 'não pode existir entre menos que duas pessoas.",224

O ser humano, portanto, tem sede da verdade, quer descobrir e investigar, com o objetivo de se alcançar a verdade. Porém, para que a mesma seja alcançada, necessário se faz acreditar na existência de Deus e em sua obra, pois Ele é o criador de tudo e apresenta a verdade. A essência da verdade absoluta está Nele e o ser humano, como sua criatura, participa dessa verdade, pois não seria capaz de conhecer a verdade longe do Criador.

Deus criou e configurou de tal maneira a natureza humana que os desejos do nosso espírito e do nosso coração se dirigem, sempre e em toda parte, para o infinito eterno, e só encontram o seu descanso em Deus. O nosso espírito reclama um saber sem limites, o nosso coração exige um ser amado que o possa satisfazer por completo e dar-lhe uma felicidade plena e eterna. As nossas pequenas alegrias

${ }^{224}$ RUBIO, A. G., Unidade na pluralidade: o ser humano à luz da fé e da reflexão cristãs, p.103. 
desta vida aspiram a desembocar numa alegria sem fim. Tudo quanto de nobre existe no homem orienta-se sempre para uma vida de uma largueza e de uma profundidade infinitas: em última análise, para a posse da vida divina. ${ }^{225}$

\subsection{0 \\ Restaurado em Jesus Cristo e Santificado no Espírito}

A restauração do ser humano, por meio de Jesus Cristo, vem do profundo desejo de Deus não querer que nenhum ser humano se perca. A história da humanidade é marcada pela desobediência do ser humano e pela sua infidelidade ao projeto de amor de Deus. Ao mesmo tempo, ela é cheia da presença de profetas, enviados por Ele, que convocam os seres humanos a se unirem a Ele.

Apesar de todos os profetas enviados para fazerem esse convite de união pessoal e comunitário com Deus, somente Jesus Cristo teve o poder de perdoar os pecados, restaurar a vida do ser humano, pois Ele é o próprio Deus encarnado na humanidade.

Esse amor restaurador de Deus, manifestado em Jesus Cristo, é um amor libertador, que não aprisiona, nem limita a vontade do ser humano. Respeita as suas opções e decisões. O ser humano pode negar, livremente, aquilo que lhe foi oferecido pelo seu Criador, mas Deus jamais desiste dele, sempre luta pela sua vida e felicidade plena e, por isso, envia seu Filho Jesus Cristo, que convida os seres humanos à conversão, perdoando seus pecados e oferecendo a cura espiritual e física à humanidade (Cf. Mc.10, 46ss). Por fim, entrega a sua própria vida pela restauração dos seres humanos e ressuscita pela sua salvação.

Parecer com Jesus é reproduzir a estrutura fundamental da vida Dele. É assumir para si a missão e o jeito de Jesus, vivendo com Ele a misericórdia com os outros como princípio permanente e estruturador da vida e aceitando carregar sobre si o pecado do mundo. ${ }^{226}$

O ser humano, restaurado em Cristo, tem a coragem de assumir a causa do Reino de Deus; de comprometer-se com os mais humildes, lutando por uma mudança de vida, por causas éticas e justas; pensa e vive a partir de Deus, por isso é capaz de viver em comunidade, tendo uma visão mais social, com responsabilidade e amor.

A existência cristã se caracteriza pela atitude fundamental de Jesus Cristo que enquanto vivida na condição humana corpórea e social, bem como expressiva e

\footnotetext{
${ }^{225}$ BAUR, B., A vida espiritual. São Paulo: Quadrante, 2004, p.8.

${ }^{226}$ BARROS, M., Dom Helder Câmara: profeta para os nossos dias. São Paulo: Loyola, 2011, p.166.
} 
cultural, se manifestará visivelmente na vida de cada cristão e mesmo na sociedade humana. 227

A reconciliação do ser humano para com Deus, por meio de Cristo, se manifesta pelo sacramento da eucaristia e da penitência, sendo que a palavra reconciliação deve ser acolhida no coração do homem. "Não há reconciliação sem a iniciativa de Deus, mas também não há reconciliação sem a resposta do homem.",228

Nesse caminho está outra transcendência escondida, infinita, absoluta, desejável pelo amor perfeito e soberano, que acontece e que atinge a todos sem distinção. É a ética que se apresenta como dom, ofertada pela Graça, que compreende a responsabilidade e a solidariedade.

Muitas vezes, o ser humano nasce e vive em condições e realidades que nem sempre foram escolhidas por ele, mas só dentro dessas realidades o ser humano poderá exercer a sua liberdade. Carrega tesouros e fardos, que muitas vezes não depende, diretamente, dele, por isso é indispensável apoiar-se Naquele que "existe antes de tudo" e "por quem tudo foi feito": Jesus Cristo.

O ser humano e o divino se unificam em Cristo. "O humano só encontra sua identidade profunda à medida que se abre plenamente para o divino."229 Orgulhoso, porém, por vezes, fecha-se em si mesmo, é tão autossuficiente que acredita não precisar de ninguém. "Perdendo o sentido de Deus, tende-se a perder também o sentido do homem, da sua dignidade e da sua vida" (EV 21).

O ser humano, restaurado em Jesus Cristo, vive uma vida repleta de atitudes fundamentalmente cristãs, voltada para Deus, na qual reflete à luz do próprio Cristo. O cristão vive sua liberdade e, esta tem Deus como meta, aceitando as suas indicações e permitindo maior abertura para ouvir os apelos do Espírito respondendo-os, inteiramente livre, e sabendo reconhecer o ser humano como pessoa e Deus como Deus, não O colocando a seu serviço.

Seguir a Jesus Cristo e palmilhar o seu caminho para o Pai significa fazer experiências novas, ver a vida com outros olhos, perceber dimensões escondidas da realidade, relativizar o presente passageiro, poder ultrapassar si mesmo, crescer em

\footnotetext{
${ }^{227}$ MIRANDA, M. F., A salvação de Jesus Cristo: a doutrina da graça. São Paulo: Loyola, 2004, p.237.

${ }^{228}$ NODARI, P. C. \& CESCON, E., Os sacramentos da Igreja: subsídio teológico-pastoral para formar e educar na fé. São Paulo: Paulus, 2009, p.67.

${ }^{229}$ MOSER, A., O pecado: do descrédito ao aprofundamento. $4^{\mathrm{a}}$ ed. Petrópolis: Vozes, 2006, p.327 et. seq.
} 
liberdade, abandonar-se ao amor de Deus, experimentar profundamente o risco e a felicidade da fé em Jesus Cristo. ${ }^{230}$

A santificação, em sua forma verbal, significa o processo pelo qual se separa algo ou alguém para um uso ou um propósito religioso, ou seja, tornar sagrado ou consagrar. Para a teologia cristã, o processo de santificação significa o aperfeiçoamento constante e gradual no qual o ser humano se aproxima do aspecto divino e, por consequência, se afasta do pecado, pois o seu objetivo é alcançar a salvação, oferecida por Cristo. “O Espírito Santo é, segundo Paulo, o vínculo que relaciona a filiação divina de Jesus e a nossa.",231

No momento em que o ser humano se mostra para Deus, permitindo a sua entrada, começa a se sentir mais cristão, porém, é importante lembrar que como afirma Rubio, "não é o homem quem encontra a Deus mediante práticas religiosas, mediante o esforço ascético ou qualquer outro tipo de 'obras', mas é Deus quem assume a nossa existência, a nossa linguagem e a nossa história."232

A santificação é um importante e necessário processo espiritual que deve acontecer na vida de cada cristão, pois é a vontade que Deus expressa para cada um, através de seu amor santificador. Os objetivos da santificação são o de agradar a Deus, por meio da vida e da relação com o outro; é o de tornar participante de Deus e apto para o seu serviço, por meio do cotidiano.

A santificação pelo Espírito de Deus deve começar dentro de cada ser humano, pois ela é a união do espírito humano com o Espírito divino. Por isso, as atitudes do ser humano, santificado pelo Espírito, se assemelham com as de Cristo. ${ }^{233}$ Pela santificação, o ser humano consegue saciar a sua própria sede do Criador. O espírito da criatura é o lugar onde o Senhor se abriga e se manifesta na vida da humanidade. É no espírito que Deus imprime a condição humana de ser Seu Filho e sua imagem e semelhança.

A santificação atinge a consciência humana, transformando-a em mais justa, ética e solidária. Ela, guiada pelo Espírito, respeita as limitações do outro, reconhece as suas e consegue distinguir o certo do errado. Uma consciência

\footnotetext{
${ }^{230}$ MIRANDA, M. F., A salvação de Jesus Cristo: a doutrina da graça, p.221.

${ }^{231}$ LADARIA, L. F., O Deus vivo e verdadeiro: o mistério da Trindade. São Paulo: Loyola, 2005, p.67.

${ }^{232}$ RUBIO, A. G., Unidade na pluralidade: o ser humano à luz da fé e da reflexão cristãs. São Paulo: Loyola, 2001, p.19.

${ }^{233}$ OLIVEIRA, M. A., Antropologia Filosófica Contemporânea: subjetividade e inversão teórica. São Paulo, Paulus, 2012, p.98.
} 
santificada pelo Espírito é mais sensível às necessidades humanas e mais pura para amar. A santificação do ser humano, pelo Espírito, alcança e guia as intenções desse ser. "A grandeza do ser humano depende do espaço que em sua vida é reservado ao amor."234

O Espírito Santo se faz presente na rítmica do amor, que é pura recepção e laço de amor entre o Pai e o Filho. Ele reúne a tremenda diferenciação entre o Pai e o Filho e impede uma relação funcional entre eles. É dom do Pai ao Filho e do Filho ao Pai; é a identidade na diferença do Pai e do Filho; é a identidade na diferença da communio divina de amor. É o "nós" da Trindade, analogia no âmbito da criação: a esposa que reúne o coração do marido com o dos filhos.

O Espírito Santo é o Amor que se oferece a todos os seres humanos, que por sua vez são chamados a amar e a vivê-lo por meio da ética da transcendência, e assim esse sentimento, que foi ofertado, é remetido novamente ao Amor. De Deus vem todo amor e para Deus todo ele retorna.

Da mesma forma que não é possível uma ética verdadeira sem o outro e sem o amor e a gratuidade, também não é possível uma ética sem Deus, mesmo que permaneça oculto, no silêncio da Cruz.

O ser humano, mediante a missão, leva a salvação para o mundo, a fim de que o mundo seja alcançado em sua totalidade pela salvação de Deus. Assim, a comunhão do Deus trino vai mais adiante e, através da missão, compreende toda a criação. "O amor, com efeito, é a mais profunda e a mais abrangente de todas as relações possíveis ao ser humano."235

Num mundo e numa história humana em evolução, inacabados, sujeitos ao mal e ao sofrimento, o ser humano é chamado a se comprometer na luta contra as injustiças, na vivência da compaixão e, da solidariedade ativas, sempre na defesa das vítimas, em sintonia com o caminho percorrido por Jesus de Nazaré, a máxima expressão da luta de Deus contra o mal, em suas múltiplas manifestações. ${ }^{236}$

O coração do ser humano se vê movido a vibrar quando é alcançado por aquele amor para o qual está predisposto por natureza. Esse coração é capaz de abrir-se ao oferecimento do amor de Deus e a determinar-se, novamente, em uma resposta de amor.

\footnotetext{
${ }^{234}$ PRETTO, H., A teologia tem algo a dizer a respeito do ser humano? São Paulo: Paulus, 2003, p.67.

${ }^{235}$ Ibid., p.70.

${ }^{236}$ RUBIO, A. G., A teologia da criação desafiada pela visão evolucionista da vida e do cosmo. In: RUBIO, A. G. (org.); AMADO, J. P. (org.), Fé Cristã e pensamento evolucionista: aproximações teológico-pastorais a um tema desafiador, p.53.
} 
A santificação do ser humano pelo Espírito nada mais é do que uma aproximação do amor divino, pois "Deus é amor" (1Jo 4,8). O ser humano, quanto mais se permite ser santificado pelo Espírito, mais capacidade tem de amar o próximo e a Deus, pois o amor é uma consequência da santificação. "Portanto, a vida humana também tem que ser amor, um consumir-se na chama daquele amor que é Deus." ${ }^{, 237}$ O ser humano que se deixa guiar pelo Espírito Santo sabe acolher a sua ação salvífica:

Acolher a ação do Espírito significa também estar aberto às novas interpelações de Deus, aos apelos concretos à nossa liberdade, que nos fazem crescer na autenticidade e na verdade de nosso ser cristão. Querer instalar-se no já alcançado implica fechar-se a Deus, que sempre age livremente para o nosso bem. Portanto, a fidelidade ao Evangelho desencadeia sempre um maior amadurecimento no seguimento de Cristo. Acolher a ação do Espírito significa necessariamente, já que não somos puros espíritos, expressar nossa atitude fundamental cristã e visibilizar nosso compromisso com o Reino de Deus. ${ }^{238}$

\subsection{1}

\section{O Ser Humano e a Mobilidade: Desafios}

Após analisarmos alguns das principais características do ser humano à luz da Antropologia Teológica Cristã, podemos afirmar que ele é um ser também de relações e de mobilidade.

Trouxemos algumas definições e sentidos que julgamos melhor apresentar, através de diferentes aspectos que são próprios do ser humano: sua identidade e os meios pelos quais constrói sua visão de mundo e caminha na direção de sua salvação. A partir de sua definição como criatura, reunimos aspectos que assim o constituem, tais como o corpóreo, que é aquele que permite a materialização e a expressão de seu movimento em várias direções, dando-lhe a condição para ser um ser vivente, de eleição e aliança com o outro e com o Criador, por isso sua busca pelo absoluto se confunde com sua própria natureza, que deve ser livre e pautada na verdade. Por ser um ser para o futuro, sua história passada e presente se encaminha no sentido de que ele é um ser de transformação e de ação diante da vida. Como pessoa, deve buscar viver sua aliança com o Criador, restaurado e santificado pelo Espírito, que melhor se realiza em sua natureza e na vida com os outros, em comunidade.

\footnotetext{
${ }^{237}$ BAUR, B., A vida espiritual, p.176.

${ }^{238}$ MIRANDA, M. F., A salvação de Jesus Cristo: a doutrina da graça, p.222.
} 
O ser humano só é uma pessoa enquanto vive, enquanto se movimenta, enquanto fala, se comunica, se apaixona, se empolga etc. Faz parte da vida dele ter consciência, inteligência, saber decidir pelo certo ou errado, por isso não pode se furtar de agir com responsabilidade diante das decisões tomadas. Pois, quando assim age, ele nega uma das suas capacidades humanas, fazendo com que surjam as atitudes desumanas.

Neste ponto do estudo, justificamos que, por considerarmos indispensável abordar o ser humano em seus diferentes aspectos, no sentido de melhor compreendê-lo na sua evolução histórica e social, tivemos a preocupação de trazer definições que, mais que designar termos, se propuseram a elucidar sentidos. Procuramos, pois, em nosso argumento, tratar do ser humano à luz da antropologia cristã, que difere de outras formas de abordagens e é mais propícia a fundamentar o diálogo aqui provocado.

Todos esses aspectos foram trazidos na perspectiva de contribuir para compreensão de que o ser humano é, sobretudo, um ser de movimento, dado que sua natureza é da permanente busca. Na evolução da ciência e dos conhecimentos por ele construídos, fosse pela observação da natureza, fosse por suas experiências, o ser tem sido capaz de transformar, a cada tempo histórico, o mundo, seu habitat natural, em um grande espetáculo. Os avanços tecnológicos, produtos desses conhecimentos produzidos, trouxeram um novo desenho para a realidade.

$\mathrm{Na}$ sociedade atual, em que o mundo se reconfigura, principalmente pela ação do conhecimento, o ser humano foi capaz de desenvolver-se de modo inimaginável. No entanto, parece que diante de tudo que foi capaz de construir, perdeu-se da origem do seu ser e do seu saber, que foi criação de Deus. Quando hoje contemplamos o mundo urbano, temos a impressão que alguns seres humanos se percebem como suas próprias criaturas e, como tal, utilizam sua liberdade, muitas vezes, de modo degradante. "A pessoa é capaz de escolher determinados valores por si mesma, a partir de si mesma. É chamada a se autodecidir e, em consequência, a optar.,239

Vejo uma multidão imensa de pessoas semelhantes e iguais que, sem descanso, giram em torno de si mesmas para conquistar para si pequenas alegrias comuns que preenchem seus corações. Cada uma delas, totalmente voltada para dentro de si

${ }^{239}$ RUBIO, A. G., Unidade na pluralidade: o ser humano à luz da fé e da reflexão cristãs, p.308. 
mesmas, acha-se como que indiferente à sorte das demais. Para ela, seus filhos e seus amigos particulares perfazem a humanidade. No que concerne aos outros concidadãos seus, ela está com eles, mas não os vê, toca-os, mas não os sente, vive somente em si e para si. ${ }^{240}$

Muitos foram os benefícios que a ciência promoveu na vida humana. No entanto, nem todos os seres humanos têm ainda acesso aos seus produtos, o que tem aprofundado desigualdades e afastado o ser humano de seu foco salvífico. O movimento e o estado de nomandismo da sociedade atual, considerada por muitos teóricos como pós-moderna, especialmente na vida urbana, têm levantado questões profundas e sensíveis que precisam ser trazidas à reflexão para que a humanidade possa retomar ou reconduzir seu olhar para os irmãos e assim, aceitar, de fato, o convite a participar do projeto salvífico de Deus.

O ser humano prossegue em sua história, construindo e transformando, avançando e retrocedendo. A vida se complexifica, as distâncias físicas se encurtam, no entanto, as distâncias sociais se ampliam, excluindo muitos que passam a construir modos próprios de sobrevivência, valores e identidades. $\mathrm{O}$ processo de humanização, nesses tempos atuais de mobilidade, torna-se um grande desafio para a Igreja e para as outras instituições da sociedade que têm o papel de cuidar, preservar e promover a humanização. Esta é possível, dado que o ser humano tem vocação para a plenitude de sua essência quando persevera, em sua existência, no caminho em destino ao Criador.

Como vimos nesse capítulo, a mobilidade pode favorecer a experiência que se referem aos processos de humanização. As principais contribuições acerca do ser humano da Antropologia Teológica nos mostram o ser humano também como ser de movimento. A experiência cristã é uma experiência de movimento. Contudo, quando o ser humano desfigura sua condição criatural, perde o sentido da vida, fecha-se no individualismo e no egoísmo, não busca o divino e o absoluto. Onde está a verdade, quando o corpo é coisificado, quando há indiferença em relação ao futuro, quando se afasta da sua essência de pessoa e quando não se abre para o chamado à decisão e à resposta de ser restaurado em Jesus Cristo e santificado no Espírito? Tudo isso possibilita a presença de muitos processos de desumanização.

\footnotetext{
${ }^{240}$ MOLTMANN, J., Teologia da Esperança: estudos sobre os fundamentos e as consequências de uma escatologia cristã, p.397.
} 
Após termos caminhado nesse estudo pela apresentação do fenômeno da mobilidade urbana atual e, em seguida, termos confrontado esses ambientes de mobilidade com a Antropologia Teológica e suas principais afirmações acerca do ser humano, tentamos fornecer elementos para discernir e mostrar em que aspecto o atual movimento favorece ou não aos processos de humanização. A tarefa do próximo e último capítulo será apresentar algumas indicações pastorais que ajudem a evangelizar os ambientes de mobilidade urbana atual. 


\section{3 \\ MOBILIDADE, HUMANIZAÇÃO E EVANGELIZAÇÃO}

Como visto nos capítulos anteriores, o ser humano é um ser de movimento, sendo que, para muitos povos como, por exemplo, os hebreus e outros povos do deserto do Saara e África, o seu primeiro estilo de vida foi o nômade, à procura de alimentos. Hoje, essa característica de movimento faz com que esse ser humano continue vivendo o nomadismo, porém, dentro de outro contexto, o da vida tecnológica, digital, em que o movimento acontece de modo constante, às vezes, voluntaria e, às vezes, involuntariamente, o que, se chama de mobilidade urbana.

Hoje, o movimento está na comunicação, na globalização e na velocidade com que as informações chegam até a população. Se antes, por exemplo, se movimentava para tentar descobrir territórios, hoje, em meio à mobilidade urbana, o movimento permite conhecer o mundo todo.

A dinâmica do movimento físico foi tão longe que já permitiu o ser humano ir à lua. Movimentar significa não ficar parado, significa caminhar, correr, viver, enfim, estar em movimento. É, pois, condição de vida para o ser humano. "Deixamos o espaço da sociedade arcaica na sua tranquilidade imutável para uma sociedade moderna e pós-moderna agitada, pulverizada." 325

No primeiro capítulo, foi visto que, a partir da Revolução Industrial, o processo de urbanização aconteceu de maneira mais intensa, levando o ser humano do campo para a cidade. Os processos de produção foram alterados e o trabalho manual e artesanal passou a ser substituído, gradativamente, pelas máquinas. A tecnologia com o avanço da ciência foi também modificando a relação dos seres humanos com o trabalho e na vida em sociedade. As mudanças não ocorreram apenas nos modelos e formas de produção, mas também na visão de ser humano e de mundo. O ser humano, nesse processo, começou a viver mais concretamente a sua subjetividade, com maior liberdade de ser e conquistou seu direito de ir e vir, de pensar livremente e até contestar com maior frequência e intensidade que antes.

Também no primeiro capítulo, vimos que a mobilidade livre foi tomando conta do ser humano e assim ele foi descobrindo e ampliando as suas

\footnotetext{
${ }^{325}$ LIBANIO, J. B., As lógicas da cidade: o impacto sobre a fé e sob o impacto da fé. São Paulo: Loyola, 2002, p.29.
} 
potencialidades. Já não existia mais aquela hierarquia do sistema feudal e era possível, até mesmo, mover-se dentro das classes sociais, na maioria dos grupos da sociedade ocidental. No momento em que o ser humano foi descobrindo as suas capacidades e potencialidades, também seu desenvolvimento acelerou e não parou mais. O movimento estava definitivamente instalado em sua mente e assumido no seu comportamento. O computador, a internet e o celular passaram a ser instrumentos de trabalho e lazer. Hoje, estão inseridos na rotina humana.

Os avanços tecnológicos não param e muitos se perguntam sobre o valor transformador dessas tecnologias na vida humana; se as transformações que elas promoveram e continuam promovendo realmente trazem melhorias na qualidade da vida e das relações humanas. A chamada era pós-moderna traz, como traço marcante, o pensamento do viver aqui e agora, a fugacidade e a fragilidade do estar num mundo em que o movimento parece assumir velocidade vertiginosa, em que o tempo de estar consigo e com o outro cada vez mais reduz, tornando as pessoas, muitas vezes, individualistas e solitárias.

A questão que se tem que enfrentar é se esta realidade atual pode proporcionar isolamento, uso de máscaras, de perfis falsos e falsas realidades, criando-se falsos seres humanos ${ }^{326}$ ou levar a uma melhor conscientização dos problemas atuais, a uma comunicação mundial, sem barreiras e fronteiras. A cultura, a informação e a interação estão ao alcance de todos e esse mundo móvel, de mobilidade constante, é a marca da atualidade.

Se cada vez mais a tecnologia invade as vidas, significa que cada vez mais o ser humano utiliza-se dela e isso parece não ter mais volta. Os problemas advindos das mudanças que marcam cada era da vida da civilização geram, em cada tempo, conflitos e necessidade de se buscarem soluções, o que se constitui, também, em mais uma causa do permanente movimento.

Neste capítulo, diante do cenário aqui apresentado, estabeleceremos a relação entre mobilidade, humanização e evangelização. Buscaremos conduzir o estudo de modo a suscitar a reflexão sobre a pergunta trazida pela mobilidade, a resposta da antropologia teológica e as implicações para a evangelização. Para tanto, daremos destaque aos aspectos e dimensões do ser humano que transita

${ }^{326}$ COSTA, J. F., O ponto de vista do outro: figuras da ética na ficção de Graham Greene e Phillip K. Dick. Rio de Janeiro: Garamond, 2010, p.135. 
num ambiente social de mobilidade, em tempos em que a conservação e a valorização da sua essência e existência passam a ser grande desafio, exigindo da Igreja ações imediatas que levem os cristãos a persistir na busca pelo Absoluto e na participação no prosseguimento da obra da humanização.

Implicações existenciais e pastorais precisam ser consideradas nessa tarefa a qual cabe à Igreja tornar prioritária, contribuindo de maneira decisiva na busca do ser humano pela sua preservação como ser de vocação para a verdade e a santidade.

\section{1}

\section{A Pergunta Trazida pela Mobilidade}

O ser humano de mobilidade urbana atual vive em um processo constante de mudança, como já exposto anteriormente. O mundo globalizado, o avanço científico e tecnológico, a velocidade das notícias provocam tais mudanças. O ser humano de hoje convive com rápidas variações de mentalidade, de opinião e de valores, o que resulta em crises de identidade. Já não sabe mais se o certo era como pensava outrora ou como pensa hoje. É frequente a dificuldade de se apoiar em valores antes sólidos e constantes, em identidades e inúmeras convicções que sustentavam a sociedade e a própria fé.

Neste contínuo movimentar-se, desaparecem algumas características até então consideradas fundamentais, desconcertando os que vivem nesta realidade e, dentre estes, os que refletem sobre ela, inclusive teologicamente. O que está ocorrendo com a época atual? Trata-se de uma decadência ética ou de um novo período histórico, em que novas instâncias passam a atuar de modo decisivo? E quanto ao ser humano? Experimenta ele uma decadência ético-existencial, desunamizadora ou, diante do novo quadro que se lhe apresenta, é chamado a experimentar novas chances de humanização? O movimento ou a mobilidade, vimos nos perguntando desde o início, humanizam ou não?

A tecnologia, em especial a da informação e comunicação, proporciona todos os tipos de opinião, tendo o ser humano a liberdade de escolher a qual a mais adequada a sua vida, modificando assim o seu viver. "Encontramo-nos, hoje, diante de uma situação religiosa bastante diversificada e mutável: os povos 
estão em movimento." ${ }^{327}$ Essa nova realidade nos impele a refletir sobre a pergunta trazida pela mobilidade: ela favorece o desenvolvimento do processo de humanização?

A visão unitária do ser humano que valoriza todas as dimensões e valores de criatura de Deus como, também as suas limitações, tem provocado embates nos inúmeros encontros entre ciência e fé. A mobilidade, fenômeno natural do ser humano como ser no mundo, ser em movimento, tem ocorrido de diferentes modos, revelando as características de cada tempo histórico. Os avanços urbanos atuais nunca foram tão intensos e fáceis de serem percebidos, seus efeitos têm provocado um modo próprio de ser, exigindo atenção e cuidados com o desenvolvimento dos processos de humanização.

A época em que vivemos é, ao mesmo tempo, dramática e fascinante. Se por um lado, parece que os homens vão no encalço da prosperidade material [...], por outro lado, manifesta-se a angustiante procura de sentido, a necessidade de vida interior. $^{328}$

As mudanças constantes significam sempre o novo e o atual, o valor é colocado na individualidade, tornando-se difícil manter a unidade $\mathrm{e}$ as características das pessoas. O subjetivismo também impera nesse tempo de mobilidade humana, pois exalta, no ser humano, sua individualidade, as verdades pessoais de cada um ou de um grupo.

O ser humano se vê sujeito a indagações na vida pessoal, social e comunitária, face à extrema pluralidade e mobilidade dos sistemas urbanos atuais, que dificultam estabelecer referências e normas valorativas que se sustentem por muito tempo. "Toda a escolha vale, contanto que seja escolha, e toda ordem é boa, contando que seja uma das muitas e não excluam as outras ordens."329

O ser humano, nesse mundo móvel urbano, tem dificuldades de se firmar não só em uma cidade, mas também no âmbito religioso. Ele tem dificuldades em assumir compromisso com uma comunidade ou com a própria Igreja. ${ }^{330} \mathrm{O}$ ambiente religioso passa a ser, algumas vezes, algo parecido com o próprio mercado, utilizando-se dele quando quiser, na hora que quiser, sem o

${ }^{327}$ CARTA ENCÍCLICA, Redemptoris Missio. A validade permanente do mandato missionário. $6^{\mathrm{a}}$ ed. São Paulo: Paulinas, 2003, p.52.

${ }^{328}$ Ibid, p.65.

${ }^{329}$ PINTO, M. J. F., Farinha pouca? Meu pirão primeiro! Ética Cristã e visão evolucionista: desafios. In: RUBIO, A. G. (org.) \& AMADO, J. P. (org.), Fé Cristã e pensamento evolucionista: aproximações teológico-pastorais a um tema desafiador. São Paulo: Paulinas, 2012, p.261.

${ }^{330}$ MIRANDA, M. F., Igreja e sociedade. São Paulo: Paulinas, 2009, p.170. 
compromisso cristão. Muitas vezes, só se vai à Igreja quando se sente triste, abalado, necessitado de paz. "Daí observar que esta mencionada espiritualidade pode se revelar superficial e limitada ao sentir-se bem."331

$\mathrm{Na}$ atualidade, o ser humano está muito voltado para o lucro, para a rentabilidade, utilizando-se inclusive da própria ciência e do desenvolvimento tecnológico para esse fim. O mundo materialista se contrapõe, sob este aspecto, ao mundo espiritual o que termina acentuando as desigualdades sociais. As mulheres, por exemplo, em muitas situações, continuam a ser exploradas e desvalorizadas. O mercado cada vez mais explora a sexualidade, em muitos casos, abreviando a infância. A miséria se torna ameaçadora e geradora de violência e muito sofrimento, contaminando o ambiente da convivência como uma espécie de doença na sociedade. Viver em uma comunidade planetária e de universo móvel requer evangelização focada na melhoria dos processos de humanização, que permitam ao ser humano vida digna.

A Igreja é chamada a estar atenta às mudanças culturais, aos novos estilos de vida e aos novos comportamentos de modo a compreender as mudanças e com elas dialogar no sentido de conduzir os seres humanos à reflexão sobre o estar no mundo, reconstruindo a realidade sobre bases duradouras encontradas no evangelho.

As necessidades humanas de confraternização, diálogo, convívio, partilha fazem com que o ser humano se reúna. E a Igreja também é chamada a reconhecer e valorizar esses momentos para que sua atuação seja de fato evangelizadora, pois o testemunho se faz condição necessária da vivência da fé.

Nada do que é humano é alheio à fé cristã. Essa compreensão integral do Reino de Deus não elimina, entretanto, a tensão em âmbito individual. Pois, no fundo, é a ação do Espírito Santo que nos leva ao compromisso pelo mundo, em sentido amplo, que não se reduz só ao social, embora este seja o mais óbvio em nossos dias. $^{332}$

As pessoas desejam ser ouvidas e compreendidas em sua realidade e a Igreja deve, portanto, acolher. A mobilidade, em tempos de valorização da tecnologia e da ciência, provoca nas pessoas a necessidade desse acolhimento, e a Igreja deve fazê-lo com simplicidade e grandeza, valorizando essa busca do outro como importante oportunidade para evangelizar. Essa ação, no entanto, requer

\footnotetext{
${ }^{331}$ MIRANDA, M. F., Igreja e sociedade, p.125.

${ }^{332}$ Ibid, p.134.
} 
mudanças nos modelos e mecanismos até aqui utilizados, pois, no tempo presente, com os avanços tão sofisticados e mesmo inimagináveis, as pessoas continuam com sede de Deus.

Inovar, mudar de mentalidade, abrir-se ao novo, buscar reconstruir atitudes, este é o grande desafio que se impõe à Igreja, pois ela deve ser viva, aberta e dinâmica na medida em que é conduzida pela ação do Espírito Santo. É Ele quem a conduz, inspira e impulsiona. Porém, para isso acontecer, é preciso que ela esteja aberta para esse movimento e disposta a mudar no que for preciso. "Na tentativa de abertura ao futuro, sem saber muito como, a Igreja redescobre sua origem e seu lugar natural: procede do Deus humilde e é chamada a participar da sua ação, como instrumento disponível e fiel." ${ }^{333}$

A humanidade é motivada a deixar-se conduzir pela graça do Espírito Santo nesse tempo de mobilidade constante para conseguir redescobrir-se como Igreja, disposta a um maior diálogo com o diferente, com a ciência, com a política e com a técnica. É preciso valorizar o testemunho como mecanismo fundamental no processo de evangelização, pois ele, mais do que nunca, é essencial para que a Igreja consiga enfrentar a realidade. A exigência é de:

Uma Igreja com olhos e ouvidos abertos ao momento atual, que aprenda das pessoas e dos contextos, que vá evoluindo na compreensão própria e que valoriza o passado, mas se projeta no futuro. Uma Igreja humilde, que reconhece não saber todas as respostas, por isso, sempre e cada vez mais, tem de se colocar à escuta do Espírito para poder seguir a correnteza em busca de sinalizar que Deus está presente neste momento [...] vivendo constantemente alimentada pela esperança. ${ }^{334}$

Essa reflexão nos reconduz à pergunta que a mobilidade enseja a respeito do processo de humanização para a ela acrescentar o papel que a Igreja é chamada a desempenhar, no sentido de apresentar aos fiéis uma proposta de vida que favoreça a convivência e a partilha entre as pessoas. Isso será possível se a Igreja se apresentar como disponível a caminhar lado a lado, contribuindo para que o ser humano se perceba numa visão de conjunto: ser físico, emocional e espiritual, criatura que necessita se entender para viver nesta realidade. "É toda uma postura nova que nos é pedida, caracterizada pela tolerância e pelo diálogo." 335

\footnotetext{
${ }^{333}$ TEPEDINO, A. M. A. L., Uma Igreja em Kénose. In: RUBIO, A. G. (org.) \& AMADO, J. P. (org.), Fé Cristã e pensamento evolucionista: aproximações teológico-pastorais a um tema desafiador, p.323.

${ }^{334}$ Ibid., p.325.

${ }^{335}$ MIRANDA, M. F., A Igreja numa sociedade fragmentada. São Paulo: Loyola, 2006, p.298.
} 
Não é possível ser cristão e ser indiferente às situações que desfiguram e desumanizam o ser humano. Em Jesus Cristo, deve-se fazer e aprender uma leitura positiva da vida, com motivações de libertação, justiça e fraternidade contra tudo o que é antirreino. É muito importante que a mensagem cristã "apareça como um apelo significativo à liberdade, como uma opção em sintonia profunda com os anseios da pessoa humana, como um compromisso na construção de uma humanidade mais justa e mais fraterna."336

Ser cristão, também inclui pensar a respeito da resposta para a pergunta que a mobilidade nos tempos atuais reivindica, uma vez que exige buscar tudo o que é verdadeiramente humano e colocar Jesus Cristo no centro da tarefa comum. Ele viveu sempre para os outros, de modo que todo o seu comportamento, suas ações, suas palavras correspondiam àquilo que o Pai queria, revelando-nos um Deus de amor, compaixão e misericórdia. A linguagem do amor é a que todos compreendem, e o amor não discrimina, não oprime, não limita.

O cristão é, pois, aquele que procura agir do modo de Deus, amar como Ele e em consequência, gradativamente estar sensível aos mais carentes. É a gratuidade da consciência mediante à lógica desumana do interesse. A verdade cristã não é teórica, mas é vida acontecendo, é movimento, é existência se realizando em Jesus Cristo. Um grande desafio é a construção de um ethos comum para toda a humanidade, "pois o plano de Deus é fazer de toda a humanidade um só povo, uma só família, uma só comunhão"337 (AG 7).

Nos espaços de mobilidade urbana atual não falta a graça de Deus, nem a fé é menor do que em outros ambientes mais estáticos, apenas os seres humanos se deparam mais fortemente com a exigência da prática pastoral. Por isso, torna-se necessária a criação de comunidades de vida e de testemunho cristão para ajudar o ser humano. "O centro urbano é democrático. A verdade se constrói no confronto ideológico, no diálogo em busca do consenso." 338

Os ambientes móveis urbanos contemporâneos favorecem ao individualismo, à solidão, aos interesses particulares, à rapidez, à confusão de valores e à perda de identidade. Construir laços de amizade, promover encontros e

\footnotetext{
${ }^{336}$ MIRANDA, M. F., A Igreja numa sociedade fragmentada, p.166.

${ }^{337}$ Ibid., p. 274.

${ }^{338}$ LIBANIO, J. B., As lógicas da cidade: o impacto sobre a fé e sob o impacto da fé, p.80.
} 
valorizar a experiência cristã, tornou-se um ponto primordial para a Igreja, que deve favorecer a comunhão e ser escola de vida cristã.

Rahner afirmava que o cristão do futuro era um místico ou não seria cristão $^{339}$, e um dos caminhos da mística cristã está no engajamento e no serviço dentro de uma comunidade cristã. A comunidade exerce um papel importante no processo de humanização, uma vocação a serviço, que sendo ativa e criativa, vive a fé, defende e cuida da primazia absoluta da pessoa. A fé cristã exerce uma ação sobre a crise de valores, age denunciando sua existência, aponta causas e oferece caminhos; também reafirma sua dimensão comunitária-profética e crítica protegendo a fé do formalismo vazio e da fragmentação contemporânea. "Na vida em comunidade, pouco a pouco, consolida-se a mentalidade evangélica, que se expressa na lógica do amor, da partilha, do dom de si." ${ }^{340}$

Outra realidade que se destaca nos ambientes de mobilidade urbana atual é a participação pastoral. Criou-se a percepção de que ela diminui à medida que aumenta a urbanização, o que não é verdade. A cidade proporciona um pluralismo religioso que oferece e permite uma participação mais pessoal, escolhida. A cidade, em mobilidade, modifica o tipo de participação, deslocando para os grupos secundários e terciários a vivência cristã. Nesse contexto, a fé cristã se sente questionada, mas também questiona e busca articular cada vez mais o compromisso da fé e da prática, ou seja, o desafio da práxis, do testemunho, enfrentando o mercantilismo da fé. "Toda vida de Jesus Cristo foi levar seus semelhantes à mesma atitude fundamental, pondo-se totalmente a serviço do Reino de Deus." ${ }^{341}$

O cristão é interpelado, a partir de sua perspectiva de fé, a uma atitude crítica em relação ao império do mercado, das imposições neoliberais e de seus valores culturais e religiosos, o que exige uma participação consciente e responsável. Diante do subjetivismo e do individualismo, a fé cristã é chamada a responder com realismo e objetividade contra as propostas de secularismo, gnosticismo e misticismo que desviaram a revelação de Deus, que é Jesus Cristo.

\footnotetext{
${ }^{339}$ RAHNER, K., Espiritualidad Antigua y actual. In: Escritos de Teologia, VII. Madrid: Taurus, 1967, p.25. In: SUSIN L. C., Mysterium Creationis. Um olhar interdisciplinar sobre o Universo. São Paulo: Paulinas, 1999, p.314.

${ }^{340}$ CNBB. Evangelização e missão profética da Igreja: novos desafios. $2^{\mathrm{a}}$ ed. São Paulo: Paulinas, 2005, p.60.

${ }^{341}$ MIRANDA, M. F., Igreja e sociedade, p.60.
} 
Enquanto centro econômico, o ambiente urbano atual testa a dimensão profética da fé, e enquanto centro democrático suscita desconforto numa Igreja antes mais centralizada do que participativa. A fé cristã é uma entre muitas propostas e não pode cair no risco de calar-se ou de igualar-se às mercadorias do consumo midiático. Religião, religiosidade e fé formam um caminho semântico e há um elemento comum que atravessa as três, que é a experiência que relaciona o ser humano com uma realidade maior: o transcendente, o absoluto, o mistério. Responde a uma dimensão profunda das pessoas e nessa relação o ser humano se percebe interpelado por uma palavra reveladora de Deus e a acolhe, com exigência ética de vida e fé. "A ética acolhe transformações e mudanças que atendam a essas exigências." 342

O que está em jogo entre tantas mudanças nos processos de mobilidade urbana atual é a mudança rápida e radical dos valores que constituem um desafio no processo de humanização. É preciso viver a fé cristã com prática, vocação profética e missionária nos ambientes urbanos atuais.

A fé cristã quer trazer uma contribuição positiva à solidão da grande cidade, à dificuldade de participação, ao retomar no início do cristianismo a vida de comunidade, agora, porém em forma de "rede de comunidade". Esta proposta vem ao encontro do mal-estar que cresce. $\mathrm{O}$ mundo da vida e da convivência reclama por novos espaços. A Igreja pode oferecê-los de seu lado e assim transformar a pastoral. $^{343}$

O cultivo da fé e do amor anunciado por Jesus Cristo é o permanente exercício que suscita nos seres humanos a busca por humanidade. A reflexão acerca dos valores cristãos, sobre a ética da responsabilidade, na sociedade de mobilidade, incrementada, na atualidade, pelos meios virtuais, deve suscitar da Igreja ações conectadas com esse tempo, especialmente, entre os jovens que, em processo de formação, estão mais suscetíveis às influências de ideologias, em sua maioria, veiculadas pelas mídias e meios virtuais como as redes sociais, por exemplo. A ação da Igreja necessita ser acolhedora, amorosa e, principalmente, educadora e formadora do ser humano, cuja vocação é a santidade.

Deste modo, se o ser humano apresentou um período histórica e socialmente nômade, sedentarizando-se em seguida, buscamos afirmar, nesta dissertação, que o mundo, ou pelo menos uma parcela significativa deste mundo globalizado, está

\footnotetext{
${ }^{342}$ BOFF, L., A águia e a galinha: uma metáfora da condição humana, $38^{a}$ ed. Petrópolis: Vozes, 2002, p.94.

${ }^{343}$ LIBANO, J., As lógicas da cidade: o impacto sobre a fé e sob o impacto da fé, p.161.
} 
ingressando ou mesmo já ingressou numa nova etapa da organização social, econômica, cultural e pessoal. A esta etapa, chamamos de um novo tipo nomadismo, o qual já não se restringe às mudanças de locais realizadas pelas tribos em busca de alimento e proteção. Se, por um lado, é verdadeiro que o ser humano atual se movimenta geoespacialmente, bem mais do que o fazia em décadas não muito distantes, por outro, mais verdade ainda é o fato de que esse movimento não se restringe ao geoespacial. O ser humano, com uma facilidade nunca antes experimentada, se movimenta espacial, social, cultural e religiosamente, se nos atemos apenas a instâncias mais destacáveis. Para responder as perguntas que esta nova mobilidade urbana traz para os processos de humanização, necessitamos recorrer à concepção de ser humano conforme a experiência cristã.

\section{2}

\section{A Resposta Cristã}

A experiência cristã é uma experiência de movimento. esse movimento sempre foi caracterizado de Deus para o povo e do povo para Deus, portanto uma das características mais marcantes desse povo é a mobilidade.

A figura do pastor e de sua vida, predominantemente itinerante, tem um lugar privilegiado na revelação bíblica. Na origem do povo de Israel encontramos a figura de Abraão, que recebe como primeira indicação de Deus: "sai da tua terra, do meio dos teus parentes e da casa de teu pai, e vai para a terra que Eu te mostrar" (Gn 12, 1). Abraão partiu sem saber para aonde ia (Cf. Hb 11, 8) e, daquele momento em diante, sua vida foi marcada por contínuos deslocamentos, de acampamento em acampamento (Cf. Gn 13, 3), morando em tendas (Cf. Hb 11, 9), sabendo que também seus descendentes imediatos seriam "estrangeiros numa terra que não é deles" (Gn 15, 13). O pacto da aliança de Deus com Abraão, a imagem do itinerante, aparece como sinal privilegiado da resposta humana.

Mais adiante, o povo eleito é confiado à orientação de Moisés. Ele recebeu do Senhor o dever de libertar os israelitas da escravidão do Egito para levá-los à Terra Prometida, e isto se realizou por meio de uma longa caminhada durante a qual eles "erravam pelo deserto solitário, sem achar um caminho para a cidade habitada" (S1 107, 4). Foi precisamente nesse contexto itinerante que se deu a confirmação da aliança de Deus com seu povo no Monte Sinai. Um dos símbolos 
da aliança foi a Arca, que se deslocava com o povo e o acompanhava no caminho rumo à Terra Prometida. Essa mobilidade será posteriormente cantada e rezada nos salmos: “ó Deus, quando saías à frente do teu povo, caminhando pelo deserto, a terra tremeu e o céu dissolveu-se diante de Deus do Sinai, diante de Deus, o Deus de Israel" (S1 68, 8-9). Esses tempos forjaram a alma de Israel e foi conservada sempre viva e evocada pelas peregrinações que os hebreus faziam à Cidade Santa onde, no Templo, era guardada a Arca da Aliança.

Jesus Cristo veio para fortalecer, elevar, plenificar, mas também corrigir o esforço humano de todas as culturas. Veio ao encontro da busca, da pergunta e da reposta. Sua vida terrena de Jesus Cristo é marcada, desde seu início, pela itinerância: na fuga da perseguição de Herodes rumo ao Egito e no regresso a Nazaré. Além disso, o Evangelho testemunha as peregrinações anuais ao templo de Jerusalém e todo o seu ministério público é caracterizado pelos deslocamentos de uma região para a outra, a ponto de dizer "o Filho do homem não tem onde reclinar a cabeça” (Mt 8, 20).

Ele andava de lugar em lugar. Além de andar, convivia com o povo, acolhia pecadores públicos e ficava amigo de todos, elogiava a fé dos pagãos e fez, entre eles, o maior número de milagres. Atingiu em cheio a alma do povo de Israel. Por isso, junto à questão sociopolítica e econômica, a questão cultural causou incômodos e fez crescer o despeito e o ódio nas autoridades pagãs sedentárias daquela época, mas, sobretudo, nos religiosos, que abandonaram o nomadismo e não sabiam mais caminhar com seu povo. Ele ensinou a seus discípulos a acompanhar a realidade junto do povo. "Um Deus que nos precedeu e precede, que se pôs, ele mesmo, a caminho pelas estradas do homem, um Deus que não nos olha de cima, mas fez-se nosso companheiro de viagem." 344

Sempre andando de lugar em lugar, de aldeia em aldeia, ao longo do mar da Galiléia, sobre forte sol e enfrentando ventos, durante tempestade ou sob a luz das estrelas nas montanhas da Judéia, Jesus Cristo assume, publicamente, a plenitude do profetismo nômade; é o Sumo e Eterno Sacerdote, com vestes, gestos e costumes de seu povo. O Galileu itinerante atraiu seguidores que se tornaram seus apóstolos e discípulos. Seu projeto e sua imagem histórica foram marcados por

\footnotetext{
${ }^{344}$ JOÃO PAULO II, A peregrinação aos lugares relacionados com a História da Salvação. São Paulo: Paulinas, 1999, p.19.
} 
um escândalo: a morte na cruz, que é consequência da sua fidelidade ao projeto do Pai. Ele não buscou a morte, mas a realização do Reino, a salvação do ser humano na aceitação do projeto de Deus.

O ser humano cuja grandeza é estar a caminho com os outros, consegue nascer pouco a pouco para uma experiência de liberdade, em que se reconhece no outro. "Através da experiência de si mesmo, Rahner afirma que o ser humano pode ter a experiência de estar experimentando mais do que aquilo que é tão só categorial. "345

A Igreja continua na história o caminho de Jesus Cristo, Bom Pastor, que convida e acolhe todas as pessoas. Todos sabem, por experiência, que é necessário caminhar, conhecer bem a estrada, não desanimar e acertar o caminho. Jesus Cristo é o Caminho, a Verdade e a Vida e Deus continua armando sua tenda no meio do povo.

Do Antigo ao Novo Testamento, há uma coerência profunda da mobilidade e, essencialmente, em torno da imagem do ser humano. Assim relata Wénin, em seu livro O Homem Bíblico:

\begin{abstract}
Um ser humano aberto ao reconhecimento autêntico da alteridade: a do universo, a do outro, a de Deus e também a sua própria. Um ser humano que, na escola da alteridade, descobre a liberdade que lhe é oferecida e aprende a assumi-la sem transformar numa fortaleza de individualismo e de auto-suficiência, fazendo-a, em vez disso, um lugar de aliança. Um ser humano consciente de que recebeu a vida de um outro o acolhe num espírito de reconhecimento, e abre as mãos e o coração para a justiça, a solidariedade e a partilha. ${ }^{346}$
\end{abstract}

Como criatura de Deus, feito à sua imagem e semelhança, todo ser humano se sente atraído por Deus, por seu Criador. Por isso, a pessoa busca, mesmo que inconscientemente, a verdade da sua essência, pela verdade do sentido de sua vida. Essa verdade só é possível ser encontrada em Jesus Cristo, pois Ele é a própria Verdade. Dessa forma, a sede do ser humano pela verdade só é saciada por meio da espiritualidade, do encontro com o outro, do encontro consigo mesmo e do encontro com Deus. "A reflexão sobre a criação, que diz respeito às noções de Deus e de homem, ajuda-nos a compreender o que somos e a contemplar uma dimensão fundamental de nossa existência, de nosso ser no mundo."347

\footnotetext{
${ }^{345}$ VORGRIMLER, H., Karl Rahner: experiência de Deus em sua vida e em seu pensamento. São Paulo: Paulinas, 2006, p.227.

${ }^{346}$ WÉNIN, A., O homem bíblico. São Paulo: Loyola, 2006, p.11 et. seq.

${ }^{347}$ Ibid., p.37.
} 
O próprio Deus se fez ser humano para demonstrar essa realidade, para se comunicar com a humanidade. Saber viver em comunhão é condição de vida para qualquer pessoa, pois é na comunidade que se descobre, que se torna responsável, pois nela o ser humano vai ao encontro do próximo e, assim, consegue vivenciar o amor.

O cristão é chamado a estar com os outros seres humanos, vivendo agora o amorserviço [...] e a solidariedade concreta [...]; atuando agora neste nosso mundo marcado por uma profunda ambiguidade, onde a injustiça, a vontade de poder e a dominação estão fortemente presentes [...], mas também onde os sinais do Reino de Deus vão se desenvolvendo e alimentando a esperança; vivendo agora o amorserviço e a solidariedade que visam a transformar o negativo[...], com a firme convicção de que a última palavra é a da vida, da liberdade e do amor. ${ }^{348}$

É na comunhão que a dinâmica do amor acontece. Deus concede o amor a todo ser humano, este, por sua vez, só será capaz de amar a Deus amando o próximo, e assim, na medida em que se ama o outro, que é uma criatura de Deus, ama-se o próprio Deus e faz com que o amor retorne à sua origem. A santidade do ser humano, também pelo Espírito Santo, é a vivência do amor divino em nosso cotidiano. "A pessoa que se reconhece amada gratuitamente, perdoada, acolhida [...], descobre a possibilidade de perdoar e acolher com o mesmo amor os outros". 349

O kerigma, anúncio salvífico, deve levar todo ser humano a ter um encontro pessoal e cada vez maior com Jesus Cristo. Um encontro por meio dos mais necessitados, um anúncio mais vivido do que tematizado, testemunhando o serviço da fé que salva, numa experiência pessoal e comunitária com Deus. "A Igreja não pode ignorar a atual situação do mundo e menos ainda se omitir na construção do futuro da humanidade. ${ }^{" 350}$ Viver profundamente a vida cristã como luz e sal da terra em meio às realidades de mobilidades humanas e urbanizadas atuais é fundamental. A proclamação do Reino de Deus e sua realização como "o sacramento, ou sinal, e o instrumento da íntima união com Deus e na unidade de todo o gênero humano"351 (LG, n.1).

Em sua vida marcada pela mobilidade e pelo nomadismo, Jesus Cristo alterou a concepção que o povo daquele tempo possuía a respeito de Deus. Alguns

\footnotetext{
${ }^{348}$ RUBIO, A. G., O encontro com Jesus Cristo vivo: um ensaio de cristologia para nossos dias, $14^{a}$ ed. São Paulo: Paulinas, 2010, p.116.

${ }^{349}$ CNBB. Evangelização e missão profética da Igreja: novos desafios, p.54.

${ }^{350}$ MIRANDA, M. F., Igreja e sociedade, p. 35 .

${ }^{351}$ Ibid., p. 96.
} 
séculos mais tarde, inserida na cultura helênica, a igreja formulou, por meio do adágio um só Deus em três pessoas, essa realidade que transcende ao monoteísmo absoluto e apresenta uma novidade radical para o tema dessa dissertação.

Por meio do conceito de pericorese, entendido como movimentar-se ao "redor de", a experiência cristã apresenta, na verdade, um Deus em movimento, um Deus-movimento. Se Deus mesmo é também movimento, o que dizer do ser humano criado à sua imagem e semelhança?

Tempos históricos de mobilidade não são plenamente negativos para a experiência cristã de Deus nem para a humanidade. Ao contrário, trazem em si uma rica possibilidade de manifestar aspectos que os ambientes socioculturais sedentários não permitem destacar. Tudo vai depender do modo como se assume tal contexto e, em tudo isto, como a ação evangelizadora vai ser levada adiante.

Mobilidade, portanto, implica comunhão: com a Trindade, que chama à comunhão com os irmãos nos valores celebrados na caridade, na palavra e no serviço a todos. Constituídos em dignidade e identidade com Cristo, todos são responsáveis, todos são ativos e devem participar da missão como interlocutores da mensagem redentora. Essa interlocução faz-se necessária e deve percorrer os diversos caminhos que levam os seres humanos à reflexão: a Igreja, a escola, a mídia, de modo que ciência, política, cultura e economia considerem a nova sociedade que é cada vez mais plural, diversificada, móvel e complexa. É a comunidade de fé presente na atualidade. "Todos são 'irmãos em Cristo', todos constituem a comunidade, todos são responsáveis, todos são ativos na propagação do Reino."352

É preciso voltar à pastoral da evangelização, da ação, semelhante às primeiras comunidades cristãs. ${ }^{353}$ Missão seguidora de Jesus Cristo e servidora da humanidade, testemunhando o amor de Deus com alegria. Mobilidade, portanto, implica missão.

Toda a vida deve deixar transparecer Jesus Cristo, o Reino de Deus acontecendo e o seu mistério salvífico, que é o mistério cristão de salvação, gesto divino e resposta humana, participação pessoal e vivência comunitária, memória que atualiza o passado e abre o ser para o futuro. A revelação de Deus chega a sua

\footnotetext{
${ }^{352}$ MIRANDA, M. F., Igreja e sociedade, p. 97.

${ }^{353}$ BRAVO, Benjamim, A pastoral urbana: À luz de Aparecida 10. Regional Sul: CNBB., 2008, p.123.
} 
realização quando é captada e acolhida pela pessoa humana, por intermédio do Espírito Santo.

A fé é dom de Deus e exige, não só uma nova leitura da realidade, mas, sobretudo, um início de vida, pautada na Sua palavra. O Espírito Santo não somente apresenta Jesus Cristo na história, mas igualmente compromete todos como sujeitos da própria história, atingindo os mais diversos setores, como família, educação, arte, literatura, técnica, política, economia. Onde cada ser humano vive, está a realidade e "onde há cuidado, aí desabrocha a vida humana, autenticamente humana." 354

Para responder à pergunta central de nossa pesquisa, ou seja, em que sentido os contextos socioculturais marcados por aguda mobilidade são humanizantes ou não, precisamos irrenunciavelmente recorrer às principais afirmações da antropologia teológica. Ao fazê-lo, deparamo-nos com uma série de características, descritas no capítulo anterior, as quais, por sua vez, apresentam um fio condutor significativo. Criatura, pessoa, abertura a Deus, ao outro e ao futuro, por exemplo, são aspectos constitutivos do ser humano e todas elas, na linha de pensamento desta pesquisa, são desinstaladoras, mobilizantes e levam a sair de si. Resumidas no amor, como dizíamos há pouco, apresentam o ser humano exatamente como um ser de movimento e para o movimento. Desde os relatos sobre a criação até a escatologia, a experiência cristã é uma experiência de perenidade e, portanto, de movimento.

Neste sentido, os ambientes socioculturais marcados por aguda mobilidade, não podem ser vistos apenas como positivos ou negativos. A pergunta, quando assim colocada, em chave de oposição , afirmamos, está errada. Engana-se quem inicia uma reflexão sobre a humanização nos dias atuais e estabelece como parâmetros apenas o sim ou o não. A reflexão antropológica nos mostra que o ser humano traz em si, na sua constituição, uma forte abertura à mobilidade e que esta, dependendo do modo como é assumida, pode levar à humanização ou não. Mover-se, ingressar nas dinâmicas do movimento pode ser um ato profundamente humanizador, ou, se assim quisermos dizer, libertador, pois desprende o ser humano de marcas que não pertencem ao núcleo da Fé. São, antes, marcas culturais, históricas. São perspectivas, para utilizar as categorias desta pesquisa,

${ }^{354}$ BOFF, L., A águia e a galinha: uma metáfora da condição humana, p.146. 
de um horizonte de sedentarização para o qual a regra é o não-movimento, para o qual tudo que sempre foi sempre será. Este horizonte, que também possui seus valores, apresenta limitações, entre as quais a de não facilitar ao ser humano abrirse ao novo, ao futuro e ao diferente.

Com base, pois, na caracterização do ser humano como um ser também de movimento e para o movimento, pois imagem e semelhança de um DeusMovimento, podemos passar ao último passo de nossa pesquisa, que é a indicação daquelas situações em que os contextos urbanos atuais, tão marcados pela mobilidade podem ser humanizantes ou não. Paralelamente, trataremos também das implicações para a ação evangelizadora.

\section{3 \\ Implicações para a Evangelização}

Todo ser humano é histórico e tem na razão e na liberdade características de sua identidade. Como seres de matéria, o ser humano é limitado, pois na matéria está o que quer e conhece, mas também a finitude. Isto mostra que o ser humano não se basta a si mesmo busca algo além de si. A salvação que vem da ação de Deus em Jesus Cristo dá razões a essa busca do ser humano, pois afeta todo o cotidiano e acontece sempre quando ele se volta para o seu semelhante. "Todo ser humano deveria reumanizar pessoas, comunidades e povos. É a paz que se faz solidariedade. É a esperança que se faz têmpera. É a história ousada que se faz humanismo. É hora de partir para recriar a nova humanidade.”355

A salvação do ser humano é o próprio Deus e atinge a sua totalidade, ele é chamado para o Reino de um Deus apaixonado, que o ama. Jesus Cristo revelou o amor primeiro de Deus, que para o ser humano é o sentido último de sua humanidade e história. Ele mostra quem é Deus.

Ser cristão é peregrinar dia-a-dia, momento a momento, ajudando a construir o Reino de Deus nas realidades em que vivemos. É viver encarnando em nossas vidas os critérios desse reino e ser testemunhas e seguidores de Jesus, o Mestre e Senhor. É viver com a certeza da Graça, o apoio do Espírito Santo e a materna intercessão de Maria Santíssima, Mãe de Deus e da humanidade. É despojar-se de toda vaidade e sabedorias humanas. É não querer passar aos outros uma falsa imagem de si mesmo. É colocar-se com humildade e confiança na presença do Senhor. ${ }^{356}$

\footnotetext{
${ }^{355}$ ARDUINI, J., Ética responsável e criativa. São Paulo: Paulus, 2007, p.132.

${ }^{356}$ MCC, Grupo Executivo Nacional do Movimento de Cursilhos de Cristandade do Brasil, Guia do Peregrino. Rio de Janeiro: MCC, 2003, p.11.
} 
Mas como responder ao chamado de Deus? Jesus Cristo ensina a assumi-Lo com a própria vida. A salvação jamais acontece sem o compromisso com a existência histórica de Jesus de Nazaré. Por isso, é preciso construir, ao longo da vida, essas atitudes, palavras, gestos e ações como identidade fundamental. Na ação de Deus, a resposta livre e essencial para o processo de humanização na atualidade é o amor fraterno como salvação e acolhida e a luta pela justiça intrínseca ao amor fraterno. Amor é essencialmente movimento, que vai ao encontro e acolhe o que vem. Neste sentido, a mobilidade tem em si algo de humanizante e o humano, algo de mobilidade.

Todo o ser humano tem liberdade, aliás, ele é liberdade, não apenas como escolha, mas sujeito que se entende, age e faz a si mesmo, como decisão sobre si e em relação a Deus. Uma liberdade situada, encarnada, que necessita de Deus para a Salvação, onde Ele capacita o agir livremente e nos liberta para o amor. "Esta mensagem é um apelo, uma vocação: apelo para aceitar o amor de Deus e viver Nele e Dele. ${ }^{357}$ É sempre um chamado ao movimento.

O mau uso da liberdade humana gera o pecado, portanto, a salvação integral da pessoa implica na conversão do coração e em mudanças sociopolíticas. O viver do coração corresponde ao viver da liberdade mais profunda do ser humano: o amor, que afirma a totalidade do ser humano, a realização total e plena do seu ser e de sua existência, o núcleo da salvação. Onde está o amor, se dá o início da salvação. A virtude cristã deve ser guiada e dinamizada por ele. O amor necessita de ações concretas de vida para Deus, que passa obrigatoriamente pelos outros seres humanos, pois, a ação salvífica de Deus leva na direção do outro.

O amor autêntico a Deus não pode fugir da experiência do amor autêntico humano, o amor a Deus e, simultaneamente, amor ao próximo. O contrário do amor é o medo de amar e o medo de ser livre, o medo do movimento. "O amor é o modo mais perfeito de dar glória a Deus. É pelo amor que melhor cumprimos os mandamentos divinos. ${ }^{\prime 358}$

A resposta ao amor de Deus não acontece só no amor ao nosso semelhante, mas na diminuição e na eliminação do que desumaniza e destrói a vida, porque,

\footnotetext{
${ }^{357}$ COMBLIN, J., Pastoral Urbana: o dinamismo na evangelização. $3^{\mathrm{a}}$ ed. Petrópolis-RJ: Vozes, 2002, p.32.

${ }^{358}$ BAUR, B., A vida espiritual. São Paulo: Quadrante, 2004, p.33.
} 
não existe distância entre o amor ao próximo e a prática da justiça. Nos ambientes urbanos atuais, fragmentados e de inimaginável mobilidade humana, o ser é comprometido a humanizar na evangelização, a orientar a vida para Deus, construir e modificar as opções de vida, compromisso, sensibilidade à realidade histórica e social. Viver a graça de Deus é também viver para os outros, em uma existência de conversão, de autenticidade e de expressão.

Nos ambientes onde as relações são cada vez mais instantâneas e não duradoras, o indivíduo é chamado a assumir a exigência de uma maturidade humana, social e religiosa. Um compromisso com os outros que se caracterize na verdade, na justiça e na humildade, em gestos concretos, onde os privilégios estejam na vivência da vocação do amor, onde a fraternidade que humaniza mude a postura da vida, ajudando a enfrentar os momentos sombrios que se constituem em corrupção, hipocrisia e falsidade. "O homem orgulhoso ama sua própria ilusão e auto-suficiência (...). O humilde roga ser admitido a partilhar naquilo que todos os outros receberam." ${ }^{359}$

As realidades existenciais e o vazio, como o medo, nunca estiveram tão presentes na realidade atual de mobilidade, como também as facilidades que o modelo e o mercado oferecem. Todos possuem suas verdades e constroem seus caminhos, os eixos e parâmetros na sociedade, que também são móveis. "A existência de comunidades eclesiais sadias não é apenas uma resposta ao desafio da violência. Elas constituem o espaço vital indispensável para o processo de amadurecimento na experiência do Deus cristão." ${ }^{360}$ Nelas, exercita-se autêntica mobilidade humana.

A evangelização anima e compromete com palavras e ações de esperança. O mundo individualista cria uma forma e uma vida quase que direta para chegar a Deus, que não passa pelo próximo, pela justiça, pela misericórdia. Por mais estranho que possa parecer, este mundo acaba por cercear o indivíduo dentro de si mesmo. Este mundo sedentariza existencialmente o indivíduo que é sociocultural e geograficamente nômade. A fé cristã ensina que a busca do ser humano por Deus passa, de forma indireta, pelo outro. É na história que Deus atua, revela-se, compromete-se com o ser humano e exige uma resposta. A palavra de Deus é o

\footnotetext{
${ }^{359}$ MERTON, T., Na liberdade da solidão. $2^{\mathrm{a}}$ ed. Petrópolis: Vozes, 2002, p.38.

${ }^{360}$ RUBIO, A. G., A caminho da maturidade na experiência de Deus. São Paulo: Paulinas, 2008, p.183.
} 
elemento comum de todos os tempos, palavra esta que cria história, que a interpela e que a interpreta. A história é o encontro das liberdades, a aliança de Deus com o ser humano e a liberdade humana; a história é essencialmente movimento. Nunca se foi tão livre e, ao mesmo tempo, tão limitado. Como apresentar Jesus Cristo diante do pluralismo, da massificação cultural, como sendo a experiência da verdade?

As Diretrizes da evangelização ressaltam o serviço, juntamente com o diálogo, o anúncio e ao testemunho de comunhão como de exigências intrínsecas da evangelização. $\mathrm{O}$ evangelizador se põe a serviço do dinamismo da libertação integral, da humanização, da reconciliação e da inserção social. Este serviço pressupõe o respeito aos outros, o conhecimento de concepções de vida, dos problemas existenciais, dos anseios e frustrações, das alegrias e tristezas. Exige escuta e diálogo sobre o sentido da existência, a fé em Deus e a oração com convicção religiosas da presença de "sementes do Verbo." ${ }^{361}$

Saber o que é e o que deve ser o ser humano, segundo os desígnios de Deus Criador e Salvador, torna-se uma dimensão básica quando se focaliza a pessoa humana. Essa busca é iluminada por Jesus Cristo, que mostra cada um como é e ensina quem cada um deve ser.

A constante mobilidade sem propósitos de humanidade definidos, cadenciados pelo modismo, pelo consumismo, pelas relações impessoais e irresponsáveis destituídas de valores e sentidos, apresenta um ser humano dessacralizado e constituído de subjetivismos egocêntricos, que julga e cria suas próprias regras para o alcance da felicidade. Para essa realidade, ao contrário dos aspectos econômicos e técnicos, têm sido poucos os êxitos científicos que buscam superar as ambiguidades e anti-humanismos presentes na sociedade. Sem uma referência a Jesus Cristo, é impossível comunicar a verdade sobre o ser humano, Ele é o modelo da humanidade e mostra uma visão unitária desse ser. Não se pode apenas contar com forças pessoais, pois o ser humano está ligado a Cristo pela sua decisão e resposta à vontade e ao amor de Deus. O ser humano é movimento em direção a Jesus Cristo.

A primeira vocação dos seres humanos é sê-lo em essência e existência. Eles podem responder positiva ou negativamente a esse chamado. Essa resposta é o que o torna responsável pelo processo de humanização ou não de todos de sua espécie, ou seja, cabe a ele decidir-se a responder, assumindo a decisão e as

${ }^{361}$ CNBB, Mobilidade Humana no Brasil: orientações pastorais. Brasília: CNBB, 2009, p.104. 
relações constitutivas do ser humano. "O que permite, porém, a construção coletiva da solidariedade universal é o recurso sistemático ao diálogo em todas as frentes e em todos os níveis. Impõe-se, portanto, uma ética do diálogo universal. ${ }^{, 362}$ Uma ética do movimento.

No homem Jesus de Nazaré, aprende-se o significado de humano e desumano, o indivíduo não está só nessa caminhada, pois a ação de Deus vai criando, sustentando e tornando possível o existir humano em sua liberdade. Todo ser humano é parte integrante do universo e todo o universo cabe dentro de si. Cada pessoa é única, irrepetível e insubstituível, mas sempre relacionada com os outros seres, portanto, a integração e a inclusão de todo ser humano é indispensável para seu amadurecimento com sua relação pessoal e comunitária. "A Igreja é chamada a dar sua contribuição de esperança, neste mundo."363

Encontramos entre os aspectos humanos de mobilidade atual três realidades que precisam de um precioso cuidado: família, identidade e valores éticos. A superação da indiferença e a inclusão de toda pessoa torna-se missão de todos em um processo de conscientização e humanização, sempre em favor da vida que vai sendo construída na ação de cada relacionamento humano e que clama por uma realidade compatível com um Deus que ama e nos chama ao amor.

Neste mundo de mobilidade urbana, de um intenso movimentar-se, onde o próprio tempo tornou-se curto para se cumprirem tantos compromissos, a residência tornou-se parada somente para o descanso; o estilo de vida do ser humano urbano atual mudou, assim como mudaram as famílias. Porém, esse ser, em sua essência, continua o mesmo, com necessidades humanas, com carências e em busca do Transcendente.

A família, nesse contexto de mobilidade atual, merece todo zelo e atenção pastoral da comunidade Igreja. É claro que não se sabe e nem se deve ter a pretensão de saber para onde caminha a humanidade, porém, para onde quer que vá, a família ocupa um papel de destaque e de suma importância. "A paisagem religiosa da modernidade é caracterizada por um movimento irresistível de

\footnotetext{
${ }^{362}$ BOFF, L., Ethos Mundial: um consenso mínimo entre os humanos. Rio de Janeiro: Record, 2009 , p.94.

${ }^{363}$ CNBB, Evangelização e missão profética da Igreja: novos desafios. $2^{\mathrm{a}}$ ed. São Paulo: Paulinas, 2005, p.51.
} 
individualização e de subjetivação das crenças e das práticas." ${ }^{364}$ Portanto, precisa-se saber como acolher cada um para que com os outros, humanize-se de maneira cristã a família humana universal.

A partir da necessidade do ser humano se encontrar consigo mesmo, se realizar como pessoa, se descobrir como ser humano é que se deve trabalhar a dinâmica da vida, fazendo com que se consiga enxergar o valor das relações humanas, da família e do diálogo. A família deve favorecer a dignidade da pessoa humana, o respeito, a compreensão e o diálogo.

Há imensa dificuldade para momentos de interiorização, necessários para a afetividade. Além disso, o espaço da intimidade e da interioridade da casa, das pessoas vem sendo invadido pela mídia, que ressuda sexualidade e liberação ilimitada de todo desejo. Desaparecem nas famílias as horas de conversa reestruturante da afetividade. ${ }^{365}$

Hoje, mesmo que a família encontre menos tempo para estar reunida, ela deve fazer com que esses pequenos encontros tenham qualidade, sentido e valor. O desafio é encontrar equilíbrio entre a rotina familiar e a rotina do trabalho. A grandeza das relações humanas pessoais não pode, não deve e não é substituída por nenhuma comunidade virtual. Esses sentidos são exercitados nas relações dos seres humanos entre si e com a natureza, de maneira também física, presente e autêntica.

Uma das características que se apresenta como outro desafio no serviço de evangelização são as identidades que emergem num mundo globalizado e de mobilidade constante. Conexões internas transitam pelo universo on-line, em passos rápidos e múltiplos, as fronteiras geográficas já não existem, as possibilidades de interfaces e informações são ilimitadas.

$\mathrm{O}$ individualismo traça essas identidades humanas, frágeis, efêmeras e plurais, que se deixam levar, por exemplo, pelo consumo de produtos sedutoramente mostrados pelo mercado para serem utilizados universal, indiscriminada e, muitas vezes, desnecessariamente, necessidades fabricadas. Nesse contexto, identidades são manipuladas e substituídas por meio do processo permanente de aculturação, que é fortalecido pelas mídias. É o querer estar sempre sintonizado na vida, mas com circunstâncias extremamente transitórias. A

\footnotetext{
${ }^{364}$ HERVIEU-LÉGER, D., O peregrino e o convertido: a religião em movimento. Petrópolis-RJ: Vozes, 2008, p.139.

${ }^{365}$ LIBANIO, J. B., As lógicas da cidade: o impacto sobre a fé e sob o impacto da fé. São Paulo: Loyola, 2002, p.41.
} 
transitoriedade está associada à aquisição de bens do momento. É necessário transitar nesse universo o tempo inteiro, a cada momento, em cada novo grupo, para ser aceito, participar e ter uma nova identidade que dê conta do aqui e agora, para ser considerado atual. "Assim, a aparência torna-se o objeto da forma de avaliação que pode ser realizada pelo olhar, ou seja, uma avaliação estética, segundo critérios tais como belo ou fastidioso, maçante ou fascinante. ${ }^{\text {366 }}$ Neste sentido, o movimento torna-se desumanizante.

Consequentemente, torna-se extremamente necessário, agir nos ambientes urbanos atuais e perceber que as novas gerações têm padrões de conduta e modo de pensar, sentir e agir que revelam uma ruptura mais radical com as gerações passadas, com os valores da história, da tradição e da própria Igreja. A própria tradição transmitida pelos pais, que implicava, de forma decisiva, a identidade do ser humano e a constituição de sujeitos e do mundo, encontra-se um pouco fragilizada; os valores que definiam o que é ser humano tornaram-se muito questionáveis.

Só se questiona algo que incomoda e a crise de valores já está incomodando a sociedade, isto porque esse ser urbano atual está em busca de algo. Nesse momento, a Igreja tem grande responsabilidade e potencialidade para apresentar tais opções ao indivíduo, conduzindo-o e orientando-o acerca das consequências de suas escolhas, levando-o a refletir e encontrar o Caminho.

Juntamente com o trigo nasce o joio. Ao lado das identidades que ferem, humilham, desumanizam e mentem, existem as identidades que congregam, partilham, compreendem, acolhem e se revelam com verdade e amor. É aí que, mais uma vez, a Igreja pode e deve atuar, fazendo com que o ser humano se reconheça cada vez mais como um ser, verdadeiramente, humano, capaz de relacionar-se com o outro e com o Transcendente, não vendo o próximo como uma mercadoria, mas como um sujeito aberto a relações, capaz e merecedor de respeito, enfim, alguém que com ele se identifique na humanidade. " $\mathrm{O}$ fato de nós

\footnotetext{
${ }^{366}$ Henning Bech. Living together in the (post) modern world. Conferência feita na sessão sobre "Changing family structures and new forms of living together" na Conferência Europeia de Sociologia, Viena, 26-28 de agosto de 1992. In: BAUMAN, Z., Ética pós-moderna. Lisboa: Relógio D’água, 2007, p.198.
} 
seres humanos podermos ajudar-nos, mutuamente, é uma de nossas capacidades humanas únicas. ${ }^{367}$ É a meta do movimento.

A coisificação do indivíduo o desumaniza. A autodivinização torna-o arrogante e prepotente, mutilando a sua própria vocação de ser, tornando-o alguém capaz de negar e não assumir a sua responsabilidade de cocriador, pois só Deus é Deus, o ser humano é criatura. A inversão desses papéis causa a desumanização do ser humano.

É necessário decisão e respostas positivas do ser humano a Deus. Ele está perto de todos e é acessível na fé e no amor, manifestando-se por meio da realidade profundamente humana. No movimento e na dinâmica do Espírito Santo a Igreja fala, age, santifica, ensina, exorta e salva. Ela não tem nenhuma outra salvação para dar à humanidade a não ser Jesus Cristo. Ela encoraja, entusiasma, realiza a intimidade e a alegria, que na caminhada de fé, compromete e abastece o encontro do ser humano com Deus e de Deus com o ser humano. Em resumo, anúncio e testemunho, culto divino e oração, serviço ao amor e comunhão fraterna, são vínculos indispensáveis para a evangelização. Igreja que é humana, trinitária e divina. Sinal identificador da mensagem do Evangelho, de força na unidade e de salvação.

A ética torna-se também importante preocupação no agir evangelizador, uma ética que permita o respeito do mundo, da natureza, dos outros e de nós mesmos; da responsabilidade para com o mundo, com os semelhantes e com o "eu"; que promova a solidariedade com o próximo ou com o outro anônimo; da tolerância com a diferença e com os diferentes; de compromisso com a vida, que é dom sagrado de Deus. Uma ética que é crítica contundente a todas as condições que retiram do ser humano sua dignidade; ética do cuidado, da paixão e da misericórdia. Enfim, uma ética transcendente.

Chamados à permanente construção da criação, o ser humano volta-se para defender a vida e a combater a desintegração da comunhão da forma mais perversa nos ambientes móveis atuais. "E neste sentido o agir ético, o ser ético é graça em movimento, podendo configurar-se de muitas maneiras, mas que levam

\footnotetext{
${ }^{367}$ BOFF, L., em colaboração com Werner Müller, Princípio de compaixão e cuidado. PetrópolisRJ: Vozes, 2001, p.34.
} 
sempre à valorização, ao respeito, à recuperação, ao resgate da dignidade, à inclusão, à humanização."368

Para construir uma ética de responsabilidade, de amor ao semelhante, de dedicação aos mais fracos, o ser humano é chamado a uma decisão profética, a uma ética do cuidado, da compaixão e da misericórdia como diz Boff: "Se o cuidado é a constituição ontológico-existencial mais original do humano, então ela oferece a base mais segura para entender a compaixão em seu sentido fundamental." ${ }^{369}$ Estes dados definem o humano, interligados um ao outro, que se identificam no movimento em relação ao outro, em um compartilhar com o outro. É o próprio amor da vida e pela vida que provoca uma práxis libertadora. O outro é a ótica da ética. A alteridade faz mudar a maneira com que o indivíduo olha o outro e a si mesmo. Ela é a base da ética.

Alteridade é a consciência do Outro na minha vida, mas uma consciência que, muito mais que uma constatação, implica uma relação afetuosa que independem de laços de amizade, pois se instala a partir da convicção de sua importância como membro da raça humana. Alteridade não é só respeito pelo Outro, pois pode-se ser respeitoso sem entrar na dinâmica da alteridade. Alteridade é o caminho de conversão do olhar que aquece o coração e provoca a contrações em nossas entranhas... Fazer a experiência da alteridade é ver no Outro, no seu Rosto, a imagem do infinito, o vestígio de Deus e a origem da ética. ${ }^{370}$

Direcionar o modo de ser e viver com responsabilidade, com cuidado, misericórdia e alteridade, conduz e facilita os processos de humanização na realidade urbana atual de mobilidade constante, desde que sempre exista o amor como princípio norteador. A vida deve ser recriada pelo amor no movimento que aponte para a direção da plenificação do amor que é Deus, e uma comunhão com Ele e com todos os seres humanos. Uma experiência íntima com o Criador e com todo o cosmos valorizando a história no Deus que se fez história, em Jesus Cristo.

Todos têm a tarefa de repensar e buscar a imagem de Deus escondida no ser humano e nas suas relações com os outros nos ambientes urbanos atuais e de mobilidade; de modificar a postura diante das indiferenças da sociedade e da cultura, sem perder a identidade mais profunda de criaturas. Existe, pois, a necessidade da valorização da diferença e o respeito pela cultura do outro. De

\footnotetext{
${ }^{368}$ MERTON, T., Na liberdade da solidão, p.277.

${ }^{369}$ BOFF, L., em colaboração com Werner Müller, Princípio de compaixão e cuidado, p.14 et. seq.

${ }^{370}$ PINTO, M. J. F., Farinha pouca? Meu pirão primeiro. Ética Cristã e visão evolucionista: desafios. In: RUBIO, A. G. (org.) \& AMADO, J. P. (org.), Fé Cristã e pensamento evolucionista: aproximações teológico-pastorais a um tema desafiador. São Paulo: Paulinas, 2012, p. 283.
} 
acordo com Santos “[...] temos o direito a ser iguais quando a diferença nos inferioriza, temos o direito a ser diferentes quando a igualdade nos descaracteriza." ${ }^{371} \mathrm{Na}$ sociedade pós-moderna, globalizada, urge que se retome o caminho da fidelidade àquele a quem se anuncia.

O papel da Igreja também deve ser este, fazer com que o ser humano não se perca e que a ética seja lembrada e praticada tanto no ambiente pessoal como no social. Que o modelo de mobilidade urbana, especialmente aquele que se utiliza dos recursos digitais, inclua valores morais e cristãos que precisam ser assimilados nas atitudes e revelados nos comportamentos, pois sempre quem estará do outro lado da tela do computador, ou do aparelho móvel é alguém cuja natureza é semelhante à do Criador, ou seja, um ser humano. A relação que acontece no espaço virtual é uma relação entre pessoas, por essa razão, ganha importância a intervenção da Igreja no sentido de resgatar o cuidado humano também nessas relações virtuais, levando os indivíduos a refletirem sobre sua responsabilidade com os atos praticados virtualmente com o outro e com a sociedade. "A responsabilidade mostra o caráter ético da pessoa." 372

A mobilidade virtual "é a inteligência humana ampliando suas possibilidades de contato. A fé cristã mantém, porém, firme a convicção de que a presença comunitária física nunca poderá ser substituída"373 ou seja, não poderá perder de vista o benefício da aproximação franqueada pelo mundo virtual, já que o estar com o outro virtualmente também é manifestação de presença e de partilha, meios insubstituíveis de viver em comunidade.

Assim como em outros tempos - tempos da Revolução Industrial - o homem temeu ser substituído pela máquina, também no mundo virtual existe o temor da desumanização. A mobilidade virtual que nos faz estar só entre tantos e que permite o movimento também solitário, individual, traz consigo o receio de não se alcançar o objetivo desejado. Todavia, foi também esse sentimento de temor e de ameaça que em todos os tempos que fez com que o ser humano descobrisse alternativas para combater os riscos e perigos que ameaçavam sua existência.

\footnotetext{
${ }^{371}$ SANTOS, B. S., A construção multicultural da igualdade e da diferença. Disponível em: <http://www.ces.uc.pt/publicacoes/oficina/135/135pdf>. Acesso em: 03 nov. 2012.

${ }^{372}$ BOFF, L., Ethos Mundial: um consenso mínimo entre os humanos, p.93.

${ }^{373}$ LIBANIO, J. B., As lógicas da cidade: o impacto sobre a fé e sob o impacto da fé, p.81.
} 
Foram, por exemplo, as mudanças de cenário que impeliram os seres humanos a lutar contra o desemprego, a fome, a guerra e o individualismo. Hoje, o medo que assombra a sociedade tecnológica deve ser o que irá despertá-la para o encontro de soluções, reflexões e busca do outro. É o mesmo que a incitará ao movimento. O temor da desumanização, da fluidez e da fragmentação, encontrado na realidade, é o primeiro sinal de que se luta para a humanização, para a unidade e para o encontro de si, do outro e de Deus.

O Deus da história é o mesmo Deus que continua criando! Deus criador e salvador, dois aspectos da única realidade divina, realidade relacional: Deus, que é Amor em si mesmo, é também amor na relação com o ser humano, com cada uma das criaturas e com o universo inteiro. ${ }^{374}$

O Concílio Vaticano II, no ano de 1962, surgiu com o propósito de resgatar, naquela época, o objetivo de missão da Igreja, que é a solidariedade, a salvação e a libertação de todo ser humano. "Pretendeu renovar a vida e a atividade da Igreja, de acordo com as necessidades do mundo contemporâneo.. ${ }^{375}$ Os diversos documentos desse Concílio fazem alusão, direta e indiretamente, ao tema da mobilidade humana, deslocamentos humanos sempre maiores e mais intensos. ${ }^{376}$ Entre as preocupações pastorais estão a unidade da família, os direitos fundamentais da pessoa humana, o direito de ter uma pátria, de migrar e de conservar a vida e o patrimônio espiritual.

O Concílio Vaticano II abriu as portas da Igreja para acolher o diferente, ir ao encontro de todos e soube valorizar a beleza do seu tempo. Colocou a Igreja em movimento. Ele é um grande exemplo, mostrando que para evangelizar é preciso ter humildade e reconhecer que muitas vezes uma mudança é necessária.

O Concílio foi reinterpretado na América Latina de forma criativa, através das conferências episcopais[...] Na América Latina, a Conferência de Medellín (1968) busca colocar em prática a Igreja que fazia opção pelos pobres [...] de Puebla (1979), com sua eclesiologia de comunhão buscava a participação de todos(as); de Santo Domingo (1992), preocupada com a inculturação e as grandes cidades, e de Aparecida (2007), chamando-nos para sermos discípulos(as) e missionários(as) para anunciar a Boa Nova de Jesus. ${ }^{377}$

\footnotetext{
${ }^{374}$ RUBIO, A. G., A teologia da criação desafiada pela visão evolucionista da visão e do cosmo. In: RUBIO, A. G. (org.) \& AMADO, J. P. (org.), Fé Cristã e pensamento evolucionista: aproximações teológico-pastorais a um tema desafiador, p.51.

${ }^{375}$ CARTA ENCÍCLICA, Redemptoris Missio. A validade permanente do mandato missionário. $6^{\mathrm{a}}$ ed. São Paulo: Paulinas, 2003, p.5.

${ }^{376} \mathrm{CNBB}$, Mobilidade Humana no Brasil: orientações pastorais, p.62.

${ }^{377}$ TEPEDINO, A. M. A. L., Uma Igreja em Kénose. In: RUBIO, A. G. (org.) \& AMADO, J. P. (org.), Fé Cristã e pensamento evolucionista: aproximações teológico-pastorais a um tema desafiador, p.318.
} 
O Vaticano II possibilita esta razão: “o Verbo de Deus, antes de fazer-se carne para salvar ao ser humano e recapitulá-lo todo Nele, (já) estava no mundo como a verdadeira luz que ilumina a todo homem (Jo 1,9-10). ${ }^{\text {,378 }}$ Ele apresenta Jesus Cristo como critério para discernir, nas culturas, o que é compatível ou incompatível com a fé cristã. Os frutos serão conhecidos no amor ao próximo, e onde há frutos do Espírito na cultura, há vontade de Deus.

Nunca houve, por parte das religiões, tantos apelos pessoais para a conversão. Sempre é um apelo individual, para uma vida nova, para libertação, de modo a fazer com que cada pessoa tome consciência do seu estado de pobreza espiritual, do vazio de sentido da vida e busque encontrar-se por intermédio do encontro com o Criador. É sempre um apelo ao movimento. Nesta circunstância em que a pessoa se sente em estado de fraqueza e perde a falsa segurança encontrada na cultura, a evangelização deve oferecer um modelo alternativo, pondo o ser humano em contato com Jesus Cristo.

A evangelização consiste em tornar presente o anúncio da Boa Nova, que é o mesmo de antes, porém de maneira diferente. Por isso é preciso mostrar um testemunho de vida cristã alegre, livre, com metas positivas, com mensagem para o futuro, com ousadia e sem medo do novo. Necessário se faz mostrar um Deus vivo e presente, por meio do testemunho de vida. Por isso, a necessidade da sua presença em todos os ambientes em que se realiza a socialização. Trata-se de criar ambientes propícios para que o encontro com Deus, com os outros e consigo mesmo passe a ser agradável. A conversão é sempre voltada para o amor encontrado em Jesus Cristo, vocação para segui-lo. Nunca foi tão fácil, como nos ambientes móveis atuais, evangelizar, nunca foi tão fácil levar à conversão e à fé cristã, porém nunca foi tão difícil manter e viver essa fé diante de tamanha mobilidade.

Ninguém se entrega a Cristo só por motivos racionais ou intelectuais. Ninguém se converte só por pura razão. Trata-se de suscitar uma expressão de fé e de vida, que envolva a totalidade do ser humano, o ser inteiro e não somente a razão abstrata ou científica. A experiência mostra que, na atualidade, o encontro dá-se, sempre, por meio de uma experiência ou de um conjunto de experiências

\footnotetext{
${ }^{378}$ BRAVO, Benjamin, A pastoral urbana: À luz de Aparecida 10. Regional Sul: CNBB, 2008, p.50.
} 
onde todas as faculdades humanas se movem. "Na pastoral urbana é necessário seguir a rota de São Paulo: regressar às casas das cidades e aí formar a Igreja de casa." $" 379$

A humanização passa por milhares de pequenas transformações no tecido urbano atual, o desafio de passo a passo, e por passos pequenos, transformar os ambientes em lugares de humanidade. A verdadeira evangelização está no serviço a Deus através do próximo. O critério de autenticidade da vivência do Evangelho está no efeito produtivo, que promove uma vida de serviço autêntico. O Evangelho é sempre um apelo dirigido pelo próprio Deus para que se aceite o amor Dele para se viver Nele, uma verdadeira vocação.

A Igreja tem diretrizes que também foram formadas no contexto do Concílio Vaticano II e nos documentos das Conferências Episcopais. Enquanto a sociedade global pensa no enriquecimento, a economia mundial na abertura do comércio, circulação financeira e nos bens de cultura, com a entrada de capital estrangeiro, a Igreja age diferentemente: faz a opção preferencial pelos pobres, pelo desenvolvimento social moldado na solidariedade, na redução de diferenças, na defesa da vida e na construção de uma sociedade mais justa, que condiga com os pobres do Evangelho. Isto tudo é realizado pela prática e o testemunho profético.

O desafio está em agir nos ambientes urbanos, de modo a promover nas grandes cidades a convivência comunitária e fraterna entre pessoas de mobilidade constante. Nas culturas se encontra a palavra de Deus em forma de sementes do Verbo. O ser humano é chamado a construir uma comunidade de discípulos missionários de Cristo nesses ambientes de mobilidade urbana atual. "É chamado a promover uma cultura do compartilhar em contraposição a uma cultura dominante de acumulação egoísta, assumindo com seriedade a virtude da pobreza para ir ao encontro dos necessitados [...]." ${ }^{380}$ Existe uma razão para tudo isso: "porque Deus abraça "a todos e especialmente aos pobres e aos que sofrem [...] o povo pobre" ${ }^{381}$. O Papa Bento XVI afirma:

seja no socorro de suas necessidades, como também na defesa de seus direitos e na promoção comum de uma sociedade fundamentada na justiça e na paz (n.550) tudo

\footnotetext{
${ }^{379}$ BRAVO, Benjamin, A pastoral urbana: À luz de Aparecida 10, p.69.

${ }^{380}$ Ibid., p.65.

${ }^{381}$ Idem.
} 
o que tenha relação com Cristo tem relação com os pobres, e tudo o que está relacionado com os pobres clama por Jesus Cristo (n. 593). ${ }^{382}$

Ao longo da história, a Igreja sempre teve particular atenção à mobilidade humana, reconhecendo nesse fenômeno uma grande possibilidade para sua ação evangelizadora. A riqueza se encontra nos pronunciamentos doutrinais e, nas diretrizes pastorais, a Igreja atesta a relevância dada ao tema da mobilidade. Reconhece a si mesma como Igreja peregrina nesta terra. Volta-se ainda mais para todos os seres humanos, em especial os que experimentam a mobilidade geográfica, na maioria das vezes forçada.

Alguns pronunciamentos pastorais do magistério universal da Igreja, que dispensaram atenção especial para a mobilidade geofísica, impulsionadas em sua maioria por questões socioeconômicas próprias do acelerado e desumano processo de industrialização, pelo êxodo rural, pela violência e pela cultura, podem ser aqui citados a título de ilustração. São eles:

Constituição Apostólica EXSUL Família do Papa Pio XII (1952) possibilitou, naquele período de pós-guerra, oferecer particular atenção para com os itinerantes de modo a ajudá-los a conservar a fé e superar obstáculos da vida cristã; ${ }^{383}$

Encíclica Mater et Magistra (1961) do Papa João XXIII - fez exigências de justiça nas relações entre os setores produtivos e o fenômeno do êxodo rural, através dos processos de industrialização; ${ }^{384}$

Carta Apostólica Octogésima Adveniens (1971) do Papa Paulo VI por ocasião do $80^{\circ}$ aniversário da publicação da Encíclica Rerum Novarum - abordou, dentre outras, as questões da urbanização, dos jovens, das mulheres, dos trabalhadores, as discriminações, as comunicações e o meio ambiente; ${ }^{385}$

Carta Circular às Conferências Episcopais (1978) da Pontifícia Comissão para a Pastoral dos Migrantes e do Turismo - Igreja e Mobilidade - debruçou sobre o fenômeno da mobilidade humana dentro do contexto das mudanças observadas na época. A carta chama para a caridade eclesial que se traduz em

\footnotetext{
${ }^{382}$ BRAVO, Benjamin, A pastoral urbana: À luz de Aparecida 10, p. 65.

${ }^{383}$ CNBB, Mobilidade Humana no Brasil: orientações pastorais, p.60.

${ }^{384}$ CARTA ENCÍCLICA, Mater et Magistra de 1961. Disponível em: <http:// www . vatican. va/holy _ father / john _ xxiii / encyclicals / documents/hf_jxxiii_enc_15051961_mater_po.html>. Acesso em 17 jul. 2012, n.120 et. seq.

${ }^{385}$ CNBB, op. cit., p.66.
} 
hospitalidade, compreensão, valorização, que se tornam, na evangelização, o testemunho cristão; ${ }^{386}$

Instrução Erga Migrantes Caritas Christi - A caridade de Cristo para com os migrantes (2004) do Pontifício Conselho para pastoral dos migrantes e itinerantes - apresentou uma proposta eclesial às novas necessidades pastorais a fim de transformar a experiência de mobilidade em uma ocasião não só de crescimento na vida cristã, mas de nova evangelização emissão; ${ }^{387}$

Documento de Aparecida (2007) - aponta as principais causas de mobilidade, como por exemplo, a violência em suas diversas formas, a pobreza, a falta de oportunidades, o trabalho escravo e o vergonhoso tráfico de pessoas. Este documento apresentou propostas para o agir diante deste cenário que são: a experiência religiosa, a vivência comunitária, a formação bíblica-doutrinal e o compromisso missionário de toda a comunidade. ${ }^{388}$

Encíclica Caritas In Veritatis (2009) do Papa Bento XVI - chama a atenção para o desenvolvimento integral do ser humano, o cuidado de salvaguardar os direitos tanto os dos indivíduos e famílias, como os da sociedade de acolhimento, pois cada ser é uma pessoa humana e possui direitos fundamentais inalienáveis e devem ser respeitados por todos e em toda e qualquer circunstância. ${ }^{389}$

Esses documentos procuraram chamar a atenção para os problemas que as formas de mobilidade instaladas na sociedade humana, oriundas de processos desenfreados do desenvolvimento econômico e financeiro, especialmente nos período pós-segunda guerra mundial e, agravados, posteriormente, pela globalização e as ideologias da pós-modernidade, geraram desigualdades e violências que contribuíram para situações desumanizadoras. No entanto, desejase chamar a atenção para a necessidade de se refletir e buscar outras formas de evangelizar e agir nesse novo modelo de mobilidade e nomadismo que se instalou na sociedade tecnológica que inclui a do tipo virtual.

A ação evangelizadora diante desse novo tipo de mobilidade urbana atual tem como urgência promover a dignidade da pessoa, renovar e integrar a comunidade, construir uma sociedade solidária, justa e fraterna.

\footnotetext{
${ }^{386}$ CNBB, Mobilidade Humana no Brasil: orientações pastorais. Brasília: CNBB, 2009, p.67.

${ }^{387}$ Ibid., p.74.

${ }^{388}$ Ibid., p. 89 et. seq.

${ }^{389}$ Ibid., p. 81.
} 
A caridade na verdade, que Jesus Cristo testemunhou com a sua vida terrena e sobretudo com a sua morte e ressurreição, é a força propulsora principal para o verdadeiro desenvolvimento de cada pessoa e da humanidade inteira. $\mathrm{O}$ amor « caritas »- é uma força extraordinária, que impele as pessoas a comprometeremse, com coragem e generosidade, no campo da justiça e da paz. ${ }^{390}$

São passos e desafios fundamentais no mundo em movimento: a construção ou o resgate da identidade pessoal e da convivência comunitária, inclusive nos meios virtuais para conduzir o encontro pessoal com Jesus Cristo que impulsiona a promover o Reino da Vida, e diz respeito à totalidade da existência humana, numa entrega livre a Jesus, Caminho, Verdade e Vida.

A salvação de Jesus Cristo deve continuar a atingir as relações sociais entre os seres humanos, desenvolver a promoção humana e a sua autêntica libertação. É importante viver a espiritualidade do ser peregrino, aquele que vai ao encontro do outro; fazer-se mobilidade com os que se movem nas diferentes e inovadoras formas de movimento; sentir compaixão pelas alegrias e sofrimentos da pessoa que está nesse movimento. Ao experimentar Deus, que caminha com seu povo, sentir a presença de Jesus em cada pessoa em mobilidade, acolhendo nela a pessoa de Jesus Cristo. Pela fé, o cristão se une a Ele e entra em comunhão com o Pai e o Espírito Santo.

A evangelização requer serviço, juntamente com o diálogo, o anúncio e o testemunho de comunhão como exigências intrínsecas da evangelização, em que o evangelizador e o evangelizado põem-se a serviço da libertação integral da humanização, da reconciliação e da inserção social. "O testemunho da vida cristã é a primeira e insubstituível forma de missão." 391 O missionário é profeta no ambiente em que se encontra, é um semeador de esperança no mundo da mobilidade humana. Por isso, será sempre um missionário em movimento.

Para a humanização, nos ambientes de mobilidade urbana atual, faz-se necessário um acompanhamento e fortalecimento no processo de uma nova evangelização no mundo globalizado. Requer ter um olhar e a atenção de Jesus Cristo para com as pessoas que se deslocam, no sentido de contribuir para que a luz do Evangelho construa uma sociedade justa, fraterna e solidária, que é

390 CARTA ENCÍCLICA, Caritas In Veritatis de 2009. Disponível em: <http://www.vatican.va/holy_father/benedict_xvi/encyclicals/documents/hf_benxvi_enc_2009062 9_caritasinveritate_po.html>. Acesso em 17 jul. 2012, n.1.

${ }^{391}$ CARTA ENCÍCLICA, Redemptoris Missio. A validade permanente do mandato missionário, $\mathrm{p}$. 69. 
fermento na construção do Reino de Deus; representa oferecer o amor, sem distinção de religião ou de raça, respeitando em cada ser humano a dignidade inalienável de pessoa humana, criada à imagem de Deus e defender sempre a vida que é a melhor forma de humanizar.

No agir de Jesus Cristo o próprio Deus se dá a conhecer. Ele lutou para superar situações de opressão, buscou alterar situações de menos vida para situações de mais vida, e quer a libertação de todas as opressões: psíquicas, corporais, sociais, religiosas, estruturais e culturais (Cf. Mt 11,3-5; Lc 4,18-19; Mt 12,28; Mc 2,4-5).

É preciso anunciar esse Reino de Deus, como o próprio Jesus Cristo fez e ensinou, com coragem, ousadia e compaixão, dentro da realidade vivida hoje, de mobilidade urbana, inclusive a virtual. É diante desse quadro atual que o Reino de Deus deve ser anunciado, acolhido e vivido. Os espaços de movimento presentes na vida dos indivíduos em seu tempo, todos eles, precisam ser ocupados e colocados a serviço da evangelização e do desenvolvimento fraterno da humanidade. A doutrina que é o próprio ensinamento de Deus, revelado e testemunhado por Cristo, precisa ser democratizada e se fazer conhecida para todas as pessoas.

Cabe à Igreja recuperar e inculturar a verdade revelada e dar-lhe forma sempre nova, apropriada ao tempo e às culturas utilizando-se, para isso, dos mecanismos de comunicação e interação que a vida atual oferece e, dentre eles, os espaços virtuais onde a mobilidade se dá de maneira cada vez mais acelerada e ampla. "Por sua vez, a Igreja, com a inculturação torna-se um sinal mais transparente daquilo que realmente ela é, e um instrumento mais apto para a missão."392

Desde o início desta dissertação, insistimos no fato de que a cultura hoje é de mobilidade humana constante e a Igreja deve acompanhar essa mudança e se adaptar. O testemunho fiel a Cristo faz com que a Igreja seja fonte de esperança para o mundo. Os elementos essenciais da Igreja são a doutrina dos apóstolos, solidariedade e comunhão fraterna, eucaristia (partilha do pão), a oração

\footnotetext{
${ }^{392}$ CARTA ENCÍCLICA, Redemptoris Missio. A validade permanente do mandato missionário, p.85.
} 
comunitária e a verdade, pois “a verdade é luz que dá sentido e valor à caridade." $" 393$

O cristão é um migrante à procura de uma terra interior. Para ele o essencial não é estar aqui ou ali, mas sim o tipo de humanidade que é construído em si e em torno de si, qualquer que seja o lugar onde se encontre. É importante que não seja dominado pela cobiça ou desejo de concorrência com o outro, mas pratique o respeito e a fraternidade. Finalmente, é assim que se tem um caminho de viver a aliança.

Como Cristo, luz e caminho das nações, se encarnou em uma realidade concreta, a Igreja também deve situar-se a partir do contexto da mobilidade urbana e das culturas em que se encontra. A Igreja tem como princípios a comunhão e a missão na evangelização dos povos, no mundo do trabalho, da política e da cultura.

O Reino presente se identifica com fraternidade, justiça, amor, luta pela vida e respeito às culturas, que dá um colorido especial na esperança. Esse Reino é poder estar face a face com Deus em tudo e em todos. Então Deus será “[...] tudo em todos" (1Cor 15,28).

Quem ama os outros com caridade é, antes de mais nada, justo para com eles. A justiça não só não é alheia à caridade, não só não é um caminho alternativo ou paralelo à caridade, mas é « inseparável da caridade », é-lhe intrínseca. A justiça é o primeiro caminho da caridade ou, como chegou a dizer Paulo VI, « a medida mínima » dela, parte integrante daquele amor «por acções e em verdade » (1 Jo 3 , 18) a que nos exorta o apóstolo João. Por um lado, a caridade exige a justiça: o reconhecimento e o respeito dos legítimos direitos dos indivíduos e dos povos. Aquela empenha-se na construção da « cidade do homem » segundo o direito e a justiça. Por outro, a caridade supera a justiça e completa-a com a lógica do dom e do perdão. A « cidade do homem » não se move apenas por relações feitas de direitos e de deveres, mas antes e sobretudo por relações de gratuidade, misericórdia e comunhão. A caridade manifesta sempre, mesmo nas relações humanas, o amor de Deus; dá valor teologal e salvífico a todo o empenho de justiça no mundo. ${ }^{394}$

A Igreja revela mobilidade testemunhada por sua índole escatológica, que nela alimenta as tensões polares rumo ao eschaton de sua realização. A condição individual do cristão é, por consequência, como uma grande peregrinação rumo ao Reino dos Céus: “do nascimento até a morte, a condição de cada um é aquela que

\footnotetext{
${ }^{393}$ CARTA ENCÍCLICA, Caritas In Veritatis, n.3.

${ }^{394}$ Ibid., n.6.
} 
é própria do homo viator" (IM, n.7). ${ }^{395} \mathrm{O}$ ser humano vive nesta condição itinerante, quer na sua realidade objetiva, quer como visão de vida, tornando-se uma vocação permanente por meio da qual "não temos aqui uma cidade permanente, mas buscamos a cidade futura" $(\mathrm{Hb} \mathrm{13,14)}$.

Deus revela-se Criador, Pai de todos os homens e de todas as mulheres que formam uma só família, toda a humanidade. Cada pessoa foi criada à imagem de Deus (Cf. Gn 1, 27-28), em solidariedade com os outros. Assim, a relação de Deus com o ser humano é vital, fundamento da dignidade da pessoa humana. No dom da vida, Deus manifesta seu amor criador, assim como Cristo o revela a toda a humanidade, com as suas palavras e ações, com a sua paixão e ressurreição. $\mathrm{Na}$ presença atual deste amor criador, que também é redentor, somos chamados a viver numa única família enriquecida pelos dons de cada um e pelas características de cada povo. Todos são chamados a construir uma humanidade fraterna e isto se faz entrando em movimento.

A unidade da família humana manifesta-se também no reconhecimento da dignidade e da liberdade de cada pessoa, qualquer que seja sua etnia, seu país de origem e sua religião, numa relação de solidariedade com todos. A prioridade do amor pelo outro que Cristo proclamou e viveu deverá assim conduzir os cristãos ao amor incondicional por cada ser humano e a ocupar com Ele o lugar de serviço. Foi desta forma que Ele combateu, sem violência, o desejo de poder que subpugnava e desumanizava.

Na conjuntura de hoje, é necessário que a vida humana seja preservada pelo respeito aos princípios cristãos e da vida, de modo que, os homens se encontrem a si e, nos outros, se encontrem com Deus. Cabe à Igreja tornar-se presente, dialogar com essa realidade complexa e plural, fazer-se ouvir em seu caminhar evangelizador cumprindo seu papel de ensinar, acolher e salvar.

Por fim, vale reafirmar que, na realidade atual, onde as distâncias se diluem, as diferenças se evidenciam, tudo se comunica, é preciso o cuidado para não tornar a tecnologia mais um fator de desigualdade social. Hoje, a luta contra a pobreza de alimentos, de educação, de saúde, também deve ser uma luta contra a pobreza nas relações e nos meios de sustento da vida tecnológica, pois, da era

395 BULA DE PROCLAMAÇÃO DO GRANDE JUBILEU DO ANO 2000, Incarnationis mysterium. Disponível em: <http://www.vatican.va/jubilee_2000/docs/documents/hf_jp-ii_doc_ 30111998_bolla-jubilee_po.html>. Acesso em: 20 nov. 2012, n.7. 
digital, quem não participa, por falta de oportunidade, está sofrendo discriminação tecnológica e exclusão; o analfabetismo digital se constitui fator de exclusão.

O avanço tecnológico, se é capaz de promover a fragmentação do indivíduo e a perda da identidade, paradoxalmente, ele promove uma união social e global jamais vista. Nesse universo digital de tantos encontros, desencontros e contradições, universo controverso da mobilidade, para que o ser humano não perca a sua essência, é fundamental buscar e resgatar a ética pessoal e social.

$\mathrm{O}$ agir ético de Jesus pode ser uma resposta a essas questões e o mandamento do amor também pode ser vivido longe dos redutos sagrados e dos espaços eclesiais. A luta pela justiça deve ser a bandeira de cristãos e não cristãos, deve ser uma brigada humana. ${ }^{396}$

Chamar o ser humano a refletir sobre sua práxis em relação à urgência nos ambientes urbanos atuais e móveis, como condição humana, diante dos vários estilos de vida que são oferecidos na atualidade, faz-se necessário pensar, refletir e avaliar a conjuntura plural e móvel do mundo contemporâneo.

Para tentar viver nesse mundo contemporâneo, de uma maneira mais coerente, onde a liberdade individual se faz tão presente, é importante assumir, com o mesmo entusiasmo, a responsabilidade advinda dessa liberdade. A Igreja tem o papel de conscientizar, firmemente, as pessoas dessa responsabilidade, pois a liberdade é oferecida e desejada por Deus, porém a verdadeira liberdade traz consigo a responsabilidade. "Junto com a liberdade, emerge a questão do amor e do respeito ao outro." 397

Nessa dimensão de ser livre e responsável, deve-se ter sempre em mente que essa liberdade busca se firmar num tempo de grande complexidade. O sujeito dessa liberdade é criatura, é ser possuidor de corporeidade, de inteligência, de capacidade de decisão, de diálogo e de necessidades de lazer, de sociabilidade, de trabalho e de religião.

Esse é o contexto em que a Igreja precisa agir e acompanhar cada vez mais a sociedade, para ajudá-la a ter a atenção necessária em relação às consequências

\footnotetext{
${ }^{396}$ PINTO, M. J. F., Farinha pouca? Meu pirão primeiro! In: RUBIO, A. G. (org.) \& AMADO, J. P. (org.), Fé Cristã e pensamento evolucionista: aproximações teológico-pastorais a um tema desafiador. São Paulo: Paulinas, 2012, p. 276.

${ }^{397}$ AMADO, J. P., Entre Deus e Darwin: contenda ou envolvimento? A respeito dos desafios que o pensamento evolucionista apresenta para a compreensão de Deus e vice-versa. In: RUBIO, A. G. (org.) \& AMADO, J. P. (org.), Fé Cristã e pensamento evolucionista: aproximações teológicopastorais a um tema desafiador, p.88.
} 
advindas de um estilo de vida imposto pelos novos modelos de mobilidade, dos usos dos produtos dos avanços tecnológicos, especialmente os do mundo eletrônico; consequências que podem ser positivas ou negativas, dependendo do grau de responsabilidade, ressaltando, sempre, que "o amor e a vida têm a última palavra." 398

Assim, a ação evangelizadora da Igreja levará em consideração as necessidades que interpelam a sensibilidade cristã, com o dever de colaborar para a superação das contradições do crescimento econômico, cultural e tecnológico, contra a miséria, a fome e a exclusão. ${ }^{399}$

Nessa dinâmica da vida, é importante frisar a capacidade que o ser humano tem de aprender, descobrir e de investigar, pois é a partir dessa capacidade que ele cresce, amadurece e se desenvolve como pessoa em meio à sociedade. Diante de todas as dimensões do ser humano, essenciais para a sua vida, está a dimensão de ser espiritual. A religião é uma manifestação tipicamente humana, que está em seu passado, em seu presente e irá acompanhá-lo no seu futuro. O ser humano é esse ser aberto para o infinito, inacabado, com sede de algo mais, com necessidade de Deus. É o ser-criatura finita que se completa no Ser-Criador infinito; é o passageiro que vai ao encontro do eterno.

A relação com Deus é, na verdade, uma necessidade para mim. Pois assim como todos os dias precisamos respirar, assim como todos os dias precisamos de luz e de alimento, assim como, também todos os dias, precisamos de amizade e, na realidade, precisamos de determinadas pessoas, a relação com Deus pertence aos elementos que sustentam absolutamente a vida. ${ }^{400}$

A Igreja é chamada a demonstrar essa capacidade do ser humano. Deve ajudar a cada um descobrir a necessidade que tem do amor, do cuidado, do respeito que devem estar presentes nas relações pessoais, tanto presenciais como virtuais, características da mobilidade urbana atual. Também é papel da Igreja ajudar o ser humano a resgatar a noção de criatura de Deus, feita à sua imagem e semelhança. Com essa conscientização, o ser humano poderá olhar para o mundo tecnológico com o olhar do próprio Cristo e tentar utilizar-se do que lhe é oferecido da mesma maneira como Jesus Cristo o utilizaria.

\footnotetext{
${ }^{398}$ RUBIO, A. G., A caminho da maturidade na experiência de Deus. São Paulo: Paulinas, 2008, p.58.

${ }^{399}$ CNBB, Projeto Nacional de Evangelização (2004-2007): queremos ver Jesus - Caminho, Verdade e Vida. $4^{a}$ ed. São Paulo: Paulinas, 2004, p.16.

${ }^{400}$ RATZINGER, J. (Cardeal), O Sal da terra: o cristianismo e a Igreja Católica no limiar do Terceiro Milênio: um diálogo com Peter Seewald. Rio de Janeiro: Imago, 2005, p.11.
} 
Também importante revisitar o entendimento de que nesse mundo de mobilidade urbana, onde o individualismo, em inúmeras situações, impera, devese resgatar a prática do acolhimento. Saber acolher o outro que vai a seu encontro, incluindo-se neste universo aquele ser humano veiculado pelas tecnologias e vinculado à comunidade virtual, torna-se uma atitude indispensável para não se perder a noção de humanidade.

São muitas as diferenças e semelhanças que vão ao encontro da pessoa, saber compreender a todas e agir sem preconceitos. Cabe à Igreja fazer esse acolhimento de modo a despertar nos fiéis o pensamento de que, como ser humano, ele não deve perder a sua consciência, pois é ela que conduz as suas atitudes e decisões; é ela quem dá valor às relações cotidianas, mesmo diante da acelerada mobilidade urbana vivida nos dias de hoje. É essa mesma consciência que poderá fazer com que o ser humano não perca, por exemplo, no mundo virtual experimentado hoje, sua identidade de ser e de criatura que caminha ao encontro do seu Criador. A consciência tem o poder de conduzi-lo em sua mobilidade, para buscar o exercício e a prática das virtudes, como a solidariedade, a alegria do encontro com o outro e a caridade.

A vida é uma constante procura, um caminho que nunca se sabe por onde vai passar e onde vai chegar. Como os antigos hebreus do deserto e como o próprio Jesus que experimentou o nomadismo com seus apóstolos, só aqueles que têm coragem de caminhar podem viver todos os dias na certeza de chegar.

O Deus dos que caminham está presente em todas as partes da Sagrada Escritura. O Povo de Deus é chamado a caminhar e Deus caminha com seu povo. A Igreja tem uma numerosa quantidade de filhos vivendo uma itinerância real e contínua em que o acolher e o ir ao encontro do outro, bem como o respeito às diferenças, são procedimentos básicos para o estabelecimento de relações sólidas e fraternas, em uma sociedade complexa e plural.

Nessa sociedade, a Igreja precisa lutar pela salvação do povo de Deus que, diante de tantas realidades perversas encontradas nesse período de mobilidade urbana, apresenta sinais de desânimo e descrença. Também ela precisa mostrar o que existe de bom dentro dessa nova realidade, o que pode e deve ser posto a contribuir para a salvação e pleno desenvolvimento da natureza humana. 
A morte de Jesus representa o projeto de sua missão redentora: “[...] amouos até o fim" (Jo 13,1) "[...] para servir e dar a sua vida em resgate de muitos" (Mc 10,45). Esse é o exemplo do supremo amor de Cristo para com todos. A esperança cristã não aponta para a cruz, mas para o Crucificado, porque Ele é o vivente e o Ressuscitado. "A soberania de Deus deve pôr-se antes de tudo no amor, e por isso é necessário pensar no sofrimento." ${ }^{\text {401 }}$ Os pobres, os pecadores, os doentes e rejeitados pela cultura de morte, destinatários do Reino de Deus, podem contar com sua palavra, que foi confirmada pela ação poderosa de Deus: vitória sobre a morte e superação definitiva das raízes profundas de toda escravidão e limitações humanas. Deus rejeita qualquer outro projeto baseado na opressão, na injustiça ou na morte.

Com Jesus ressuscitado inicia-se o tempo da missão da Igreja, que é a esperança da concretização do Reino de Deus, iluminado pela luz do Espírito Santo.

A adesão ao Reino de Deus, o compromisso com a justiça, o esforço constante por viver a atitude fundamental de Jesus Cristo, traduzido nas realizações limitadas, sujeitas ao aperfeiçoamento e, portanto, provisórias, condicionadas por novos e imprevisíveis contextos e desafios, com os quais se depara nossa liberdade ao longo de nossa vida, significam, à luz da fé, a realização total do ser humano, o que, mais frequentemente, denominamos salvação. ${ }^{402}$

Aquele que nasceu na periferia, na pobreza e na simplicidade de uma manjedoura, que caminhou por tantas cidades e aldeias pregando o amor, o perdão e a misericórdia para com todos; que se preocupou com os mais marginalizados e, por eles, ensinou justiça e igualdade de direitos; que era profundamente sensível, afável, terno e pacífico; que foi perseguido, injustiçado, desprezado e espancado, torturado e coroado com espinhos, despido de sua dignidade, cuspido e crucificado e que remiu a todos com seu precioso sangue, com doação de vida e salvou o ser humano, ressuscitou e está entre nós, caminhando com o seu povo.

Esta pesquisa teve como finalidade indagar se os contextos de aguda mobilidade, notadamente os contextos urbanos atuais, são humanizantes ou não. Para isso, vimos que o ponto de partida consiste em considerar o termo mobilidade em sentido mais amplo do que o usual, que se restringe ao geográfico.

\footnotetext{
${ }^{401}$ LADARIA, L. F., O Deus vivo e verdadeiro: o mistério da Trindade. São Paulo: Loyola, 2005, p.90.

${ }^{402}$ MIRANDA, M. F., A Salvação de Jesus Cristo: a Doutrina da Graça. São Paulo: Loyola, 2004, p.165.
} 
O ser humano, em nossos dias, se movimenta em todas as direções, em todos os sentidos e de todas as formas. Movimenta-se, por exemplo, dentro de uma cidade, tendo que trabalhar distante da residência, pois exerce suas atividades em um outro lugar. Movimenta-se também socioeconomicamente, por ser possível ascender socialmente, por ampliar suas condições financeiras ou, ao contrário, descender, muitas vezes numa rapidez até maior que no processo de ascensão. Movimenta-se religiosamente, diante de um horizonte de forte pluralismo religioso, em que as ofertas antigas precisam se reciclar diante das novas ofertas que aparecem a cada dia, numa espécie de shopping do sagrado. Movimenta-se dentro de si mesmo, ao oscilar em critérios e valores, de acordo com as tendências indicadas, por exemplo, pela mídia.

Na medida, portanto, em que o ser humano é um ser para si, mas também para os outros e, mais ainda, para o Outro, que é Deus, podemos concluir que ele é, como já dissemos antes, um ser de movimento, um ser para o movimento. Consequentemente, um contexto de mobilidade - em que as garantias não são dadas de modo tão definitivo, tão perene como acontece nos contextos sedentários, pode ser altamente positivo conduzir o ser humano a este encontro com os outros e com o Outro, encontrando-se a si mesmo.

Quando o movimento, de que tanto falamos, for um possibilitador de alteridade, os ambientes atuais são humanizadores; quando, ao contrário, a alteridade, resumo de tudo que refletimos sobre o ser humano à luz da antropologia teológica for agredida, for considerada irrelevante, os horizontes de mobilidade são desumanizadores. Isto acontece, como indicamos antes, em várias situações. Recordamos aqui dois exemplos, por considerá-los agudos e essenciais. De um lado, deparamo-nos com o individualismo, a partir do qual a alteridade, quando não é suprimida, é reduzida a níveis muito baixos e o Eu fechado em si mesmo torna-se o critério final de todo julgamento; de outro, é a consideração dos outros seres humanos como não humanos, como ocorre nos vergonhosos casos citados de pobreza e exclusão, tráfico de drogas e de pessoas, fome, desemprego e tudo mais que conhecemos tanto. Nestes casos, os ambientes de altíssima mobilidade são desumanizadores.

A Igreja, em atitude de diálogo com todas as instâncias e tendo como base o Reino de Deus, que é amor, alteridade e, em certo sentido, movimento, participa 
deste processo de discernimento, na medida em que contribui para os processos humanizadores, entendidos como ajuda a cada ser humano a se abrir aos outros e ao Outro e ajuda toda a humanidade a superar as situações de desumanidade acima descritas. Esta foi a razão pela qual, já quase ao final da dissertação, fizemos opção por mencionar um pouco da rica história de solidariedade da Igreja com os nômades geográficos. Sua referência se deve à história pessoal do pesquisador, que neles enxerga um exemplo típico da realidade atual, que aprendeu a conviver com o nomadismo em escala mais ampla, em escala existencial, mas que ainda não aprendeu a lidar com as massas sobrantes, para quem resta, na maioria das vezes, apenas migrar. 


\section{CONCLUSÃO}

A mobilidade, na contemporaneidade, configura-se como fenômeno complexo, marcado por avanços e retrocessos em relação à integralidade do ser humano. Avança nos acessos relacionais e comunicativos com mais rapidez e facilidades e retrocede pelo desenraizamento identitário que delineia o mundo contemporâneo. Esse processo de mobilidade teve um maior crescimento com a Revolução industrial que intensificou a corrida para a urbanização, e como decorrência, possibilitou ao ser humano viver mais intensamente sua autonomia como pessoa, com liberdade e identidade.

Nestas considerações finais, deseja-se dar destaque a dois eixos da pesquisa que são essenciais, no sentido de indicar caminhos nos processos de evangelização. Um eixo diz respeito à identidade do ser humano frente à mobilidade atual e à experiência cristã nesse contexto; o outro quer despertar para o serviço pastoral mediante os processos de mobilidade atual, mostrando e resgatando aspectos positivos e negativos da mobilidade nos processos de humanização.

No decorrer de sua história, o ser humano foi aos poucos se descobrindo como um ser de potencialidades para criar, descobrir e reinventar; descobriu-se com potencialidades para mover-se, não apenas de territórios, mas também no mapa mental, criando uma permanente circulação. A partir dessa nova perspectiva, incentivada pela crescente urbanização, o ser humano vai aventurando-se cada vez mais em sua vontade de crescer, de descobrir e de movimentar-se.

A irreversível revolução tecnológica e o mundo da imagem, nos últimos anos, incentivaram mudanças e comportamentos sociais que tornaram quase impossíveis de acompanhar e analisar suas impressões nos comportamentos dos seres humanos. Esses processos se multiplicaram, rapidamente, por meio da urbanização generalizada, nas pequenas, grandes e médias cidades. Esses movimentos tecnológicos redefiniram o tempo e espaço e, principalmente, o ser humano.

O fenômeno da complexidade ocorre, justamente, por efeito das transformações vividas no mundo da ciência, que ocasionaram por meio das descobertas e inovações, avanços em todos os aspectos da vida, especialmente dos 
meios tecnológicos e da incorporação da comunicação aos processos de formação e qualificação humana, ampliando seus impactos por meio da globalização. Esta, por sua vez, transformou todo o cenário econômico e social com reflexos, por exemplo, nas relações familiares, dentre outros fatores da vida em sociedade.

A pós-modernidade traz consigo mudanças em diferentes setores da vida humana em sociedade; mudanças que trazem aspectos vantajosos como o avanço na produção do conhecimento, a rapidez na circulação das informações e facilidades na vida cotidiana, no trabalho e no lazer, além da promoção de encontros. Juntamente com as facilidades, no entanto, muitos também são os fatores negativos derivados dessas mudanças, tais como a violência, o isolamento, o individualismo, o anonimato, a irresponsabilidade e até mesmo a insatisfação identitária. A maioria das coisas se mundializou, encolheram o planeta e tudo se tornou mais próximo. Essa proximidade trouxe, enfim, para dentro de casa, o mundo com toda a sua riqueza cultural e humana, mas também, pela força do mercado, arrebatou a coisificação do ser humano e a sua desumanização.

Apesar de todo o avanço tecnológico de mobilidade constante, o ser humano se vê sem rumos definidos e estáveis, sem saber, muitas vezes, para onde moverse. Faz-se necessário construir valores que sejam para todos, não somente para os mais aptos e rápidos, para quem os limites não existem e os comportamentos tornam-se, muitas vezes, individualistas.

É singular na história humana a motilidade e a busca pelo outro. Percebe-se que a mobilidade e a estabilidade são recorrentes na sociedade, porém os processos de mobilidade nunca foram tão intensos como nos ambientes urbanos atuais.

Como visto, o ser humano é um ser criado à imagem e semelhança de Deus e com capacidade inata de pensar, descobrir e criar a realidade em que habita. Assim, é necessário anunciar o Evangelho que o promova com dignidade, consciência, capacidade de decisão e resposta livre e corajosa para Deus e para o próximo. Enxergar a integralidade do ser humano, ajudá-lo a definir-se como ser humano pela consciência faz com que ele possa reconhecer-se como pessoa. E para vencer a desumanização inserida na sociedade, percebe-se ser preciso buscar a força da decisão da consciência humana, e pela experiência cristã vencer a apatia e o medo instalados. 
É preciso fazer a experiência de filhos de Deus que, em comunhão de amor, tomam consciência de que, em primeiro lugar, vem o ser humano, que deve ser infinitamente mais valorizado do que a última novidade, seja ela a ecológica, a tecnológica, a cultural, a moral ou a religiosa. Não será suficiente, pois, mudar a catequese; é preciso mudar o estilo de vida e de evangelização. É preciso ousadia para desinstalar-se, para ir ao encontro pessoal do ser humano, perceber que toda descoberta e toda tecnologia modificam a vida do ser humano e, portanto, devem ser submetidas aos valores éticos cristãos.

A humanidade de ontem, de hoje e de amanhã depende do compromisso de cada um de resgatar o sentido e a dignidade da vida e a partir deste sentimento construir para si uma proposta cultural, cristã e salvífica. A evangelização destacase, nessa realidade, na medida em que se torna instrumento capaz de promover a ética, o cuidado nos relacionamentos e a responsabilidade nas relações pessoais e comunitárias. Um dos serviços pastorais da Igreja deve ser de conscientizar os seres humanos de sua responsabilidade, pois a liberdade é querida por Deus, no entanto, a verdadeira liberdade traz consigo a responsabilidade.

O anúncio de Jesus Cristo precisa estar inserido na sociedade, acompanhá-la em seu movimento, avaliar seus aspectos negativos e destacar os positivos, dar oportunidades ao ser humano para aprender, crescer, refletir, amar, capacidades intrínsecas a ele. É por meio de um corpo que ele consegue expressar suas emoções, sentimentos, pensamentos e agir com responsabilidade. Também é por meio do corpo que consegue se relacionar com o outro, compreender o diferente, e vivenciar o Transcendente. É importante destacar que o ser humano também é um ser espiritual, um ser de abertura para o infinito e capaz de Deus, um ser criatura finito que se completa no Ser Criador infinito. É o passageiro que vai ao encontro do eterno.

Fazer o ser humano não perder a noção de criatura de Deus, pela experiência do sagrado, é possibilitar a ele reconhecer a necessidade de se abrir para o outro e para a comunhão, pois dessa maneira estará cada vez mais encontrando e reconhecendo a Deus.

A Igreja tem a missão de ajudá-lo na construção de sua identidade e viver uma evangelização dinâmica, sem perder ou modificar a mensagem que é Jesus 
Cristo, ontem, hoje e sempre, mas numa nova releitura bíblica: a da experiência do Deus que caminha com seu povo.

É dever da Igreja investigar a todo momento os sinais dos tempos e interpretá-los à luz do Evangelho, para que assim possa responder, de modo adaptado a cada geração, às eternas perguntas dos homens acerca do sentido da vida presente e da futura, e da relação entre ambas. É, por isso, necessário conhecer e compreender o mundo em que vivemos, as suas esperanças e aspirações e o seu caráter tantas vezes dramático (GS 4).

É preciso ir ao encontro de seres humanos que se comprometam em colaborar na construção do Reino de Deus, como discípulos chamados por Jesus Cristo para com Ele conviver, participar de sua vida, unir-se a sua pessoa e aderir a sua missão. O encontro pessoal com Jesus Cristo impulsiona a promover o Reino da vida, que diz respeito à totalidade da existência humana, incluindo a sua dimensão pessoal, familiar, social, cultural e religiosa. A salvação de Jesus Cristo deve atingir as relações sociais entre os seres humanos, o que envolve a promoção humana e sua autêntica libertação.

Importante é viver a espiritualidade do peregrino, fazer mobilidade com os que se movem e sentir compaixão pelos sofrimentos dos seres humanos que estão a caminho, experimentando o Deus que caminha com seu povo. Da fé em Jesus Cristo suscitada, acolhida e partilhada nasce a comunidade, chamada a dar testemunho de comunhão.

Dessa forma, para acontecer uma evangelização eficaz neste mundo de mobilidade constante, é preciso ser evangelizador tendo a certeza de que aquilo que se fala e se faz é algo de valor e representa muito para a humanidade, para os seres humanos e para todos, pois cada ser é criatura de Deus, feito à sua imagem e semelhança. Estar sacerdote, religioso, religiosa, leigo e leiga representa apenas mais um que busca um lugar básico na sociedade e na vida. Aquele que é, assume a sua responsabilidade de ser e age, e seu agir é serviço não por conveniência, mas por vocação e convicção.

Os seres humanos experimentam hoje um tempo de solidão coletiva, de perda de sua vocação para o absoluto e de distanciamento da realização do maior mandamento de Deus: o amor. Por isso, os evangelizadores são chamados, nos dias atuais de constante mobilidade, a voltar às origens dos primeiros séculos da Igreja quando, com mais intensidade, ela era peregrina e sua prática pastoral ia ao encontro de todos os seres humanos em seus ambientes específicos e em suas 
realidades culturais; são chamados hoje a uma pastoral encarnada na história e profética nas realidades móveis, que são, por vezes, desestabilizadoras e individualizantes e ameaçam o ser humano, inclusive, a perder sua identidade de criatura divina.

Isto representa incentivar os seres humanos à reflexão a respeito de seu ser e estar no mundo, sobre como se servir dos avanços do seu tempo sem perder a sua humanidade; significa ajudar a fazer a experiência de Deus e facilitar o próprio conhecimento da fé em Deus que vem por Jesus Cristo, abrindo portas e janelas para que, como na mobilidade do Espírito Santo, possa ajudar a tornar as comunidades sem fronteiras, fraternas e solidárias; uma ação voltada para a vida em meio às diferenças $\mathrm{e} o$ diferente, e aberta para as diversidades com misericórdia. Uma pastoral que interpela para a convivência, para a comunhão, para a solidariedade e a alteridade para com os outros seres humanos; aberta, pois, aos movimentos atuais de mobilidade e disposta a caminhar com os outros, fazendo, com humildade, a experiência cristã no Deus da vida que se faz presente na história e no agora.

Ao refletirmos sobre mobilidade urbana atual, deparamo-nos com desafios para apresentar Jesus às culturas urbanas em constante mobilidade. No caminho de Jesus Cristo, Verbo de Deus, que se fez carne, que se fez Homem em tudo, exceto no pecado, a ação evangelizadora é incessantemente chamada a se encarnar nas diversas culturas, assumindo o que nelas existe de evangélico e interpelando o que nelas fere os valores do Reino de Deus.

$\mathrm{Na}$ medida em que se anuncia Jesus Cristo encarnado, o anúncio desta encarnação precisa fazer-se presente lá, onde as pessoas e povos se encontram e do modo como se encontram. Evangelizar é comunicar, e não se faz comunicação sem uma linguagem apta a estabelecer o diálogo. O que se percebe em nossos dias de mobilidade é que novamente é preciso descentralizar, ir ao encontro de pessoas e grupos lá, onde eles estão. Nunca é demais recordar que a referência do mundo urbano globalizado e de mobilidade constante não é mais a praça central da cidade como ícone da estabilidade e da proteção, mas o deserto onde o clã se reúne para viver relacionamentos mais imediatos, diretos, personalizantes e, por tudo isso, protetores. Pela mobilidade, as cidades tornaram-se fragmentadas; são cidades 
dentro de uma cidade. O anúncio de Jesus Cristo ou considera essa realidade ou não conseguirá ir às raízes da cultura urbana atual de mobilidade e dialogar.

Numa outra dimensão, a perenidade é uma categoria teológica cujas bases se encontram na raiz do Cristianismo. O relacionamento com Jesus Cristo implica adesão radical, entrega absoluta. Mais um desafio para a evangelização na mobilidade afirmar a perenidade de vínculos com Jesus Cristo por meio de um constante processo de escolha, opção e conversão. A mobilidade afeta a configuração pastoral da Igreja. É urgente um testemunho pessoal e capaz de responder, cativar e transmitir uma postura mais missionária, reconhecendo que a missão não é mais uma questão de território, mas de atitude.

Diante do quadro de forte mobilidade, o primeiro anúncio de Jesus Cristo passa a ser uma atitude prioritária no exercício evangelizador. Para a fé cristã, a salvação do ser humano é Deus. E todo ser humano se encontra no interior de um contexto vital, sociocultural e histórico. A evangelização deve possibilitar que o ser humano faça experiência de Deus na realidade concreta em que se encontra. A práxis cristã, marcada pela gratuidade, pela misericórdia, pelo perdão, pela justiça e pelo amor, recupera e fortalece o que há de melhor no ser humano e gera uma comunidade menos deformada pelo egoísmo.

Auxiliar para que a pessoa saiba que ninguém pode se constituir em ser humano senão numa sociedade humana, no interior de uma tradição cultural, no meio de outras pessoas é fundante. Somente assim, a pessoa pode usar sua inteligência e atuar em sua liberdade. É no encontro com outras pessoas que chegamos a nossa identidade pessoal. É também na comunidade que interage com os seus semelhantes que se realiza a identidade cristã. Por viver em uma sociedade humana, não podemos nos omitir em colaborar para a construção de uma sociedade melhor e de relações mais humanas. Todas as injustiças e sofrimentos, principalmente aos mais pobres, desumanizam o ser humano. A realização do Reino de Deus presente na história não se realiza no individualismo, mas na comunhão. O ser humano só se constitui como tal em relação com outros seres humanos, no amor autêntico e desinteressado aos outros.

Numa sociedade móvel e plural, marcada por diversas interpretações e práticas que acontecem numa espantosa velocidade, deixando a impressão de que 
tudo é efêmero e descartável, os seres humanos anseiam por referenciais sólidos que iluminem o cotidiano.

Jesus Cristo leva-nos a experimentar um modo novo de viver a própria vida, libertando do egocentrismo, do individualismo, e da hegemonia do econômico, superando projetos pessoais realizados pela racionalidade funcional, para fazermos a aventura do amor. E a fé cristã, a última palavra sobre a história, nos convida à construção de valores que humanizem através da evangelização nos ambientes de mobilidade atual. Caminhar com Jesus é se comprometer com o amor e a justiça. 


\section{Referências Bibliográficas}

ALMEIDA, Maria Izabel Mendes de \& TRACY, Kátia Maria de Almeida. Noites nômades: espaço e subjetividade nas culturas jovens contemporâneas. Rio de Janeiro: Rocco, 2003.

ANDRADE, Paulo Fernando Carneiro de (org) \& NEUTZLING, Inácio (org). Uma sociedade pós-humana: possibilidades e limites das nanotecnologias. São Leopoldo: Unisinos, 2009.

AQUINO, Tomás de. Summa Theologiae, I, q. 75, a. 4.

ARDUINI, Juvenal. Ética responsável e criativa. São Paulo: Paulus, 2007.

AUGÉ, Marc. Não lugares: introdução a uma antropologia da supermodernidade. São Paulo: Papirus, 1994.

BARROS, José D’Assunção. Cidade e História. Petrópolis: Vozes, 2007.

BARROS, Marcelo. Dom Helder Câmara: profeta para os nossos dias. São Paulo: Loyola, 2011.

BAUMAN, Zygmunt. A vida fragmentada: ensaios sobre a moral pós-moderna. Lisboa: Relógio D’água, 2007.

__. Ética pós-moderna. Lisboa: Relógio D’água, 2007.

Identidade. Rio de Janeiro: Jorge Zahar, 2005.

. Modernidade Líquida. Rio de Janeiro: Zahar, 2001.

1999.

Globalização: as consequências humanas. Rio de Janeiro: Jorge Zahar,

O mal-estar na pós-modernidade. Rio de Janeiro: Zahar, 1998.

BARBOTIN, Edmond. Humanité de l'homme. Strasbourg: Aubier, 1970.

BAUR, Benedikt. A vida espiritual. São Paulo: Quadrante, 2004.

BENEVOLO, Leonardo. História da Cidade. São Paulo: Perspectiva, 1993.

BÍBLIA. Português. Bíblia de Jerusalém. 5ª ed. São Paulo: Paulus, 2008.

BOFF, Leonardo. Ethos Mundial: um consenso mínimo entre os humanos. Rio de Janeiro: Record, 2009. 
A águia e a galinha: uma metáfora da condição humana. $38^{\mathrm{a}}$ ed. Petrópolis: Vozes, 2002.

, em colaboração com Werner Müller. Princípio de compaixão e cuidado. Petrópolis-RJ: Vozes, 2001. 1999.

Saber cuidar: ética do humano, compaixão pela Terra. Petrópolis: Vozes,

BRAVO, Benjamim. A pastoral urbana: À luz de Aparecida 10. Regional Sul: CNBB, 2008.

BRUMER, Anita. Gênero, família e globalização. Porto Alegre: Sociologias, n. 21, jun. 2009. Disponível em <http://www.scielo.br/scielo.php?script=sci_arttext \&pid=S151745222009000100002\&lng=pt\&nrm=iso>. Acesso em 01 out. 2012. http://dx.doi.org/10.1590/S1517-45222009000100002.

CAIAFA, Janice. Aventuras das cidades: ensaios e etnografias. Rio de Janeiro: FGV, 2007.

CARTA ENCÍCLICA. Caritas In Veritatis de 2009. Disponível em: <http://www.vatican.va/holy_father/benedict_xvi/encyclicals/documents/hf_benxvi_enc_20090629_caritas-in-veritate_po.html>. Acesso em 17 jul. 2012.

Evangelium Vitae de 1995. Disponível em: <http://www.vatican.va/holy_ father/john_paul_ii/encyclicals/documents/hf_jp-ii_enc_25031995_evangeliumvitae_po.html>. Acesso em 29 jul. 2012.

Laborem Exercens de 1981. Disponível em: <http://www.vatican.va/holy _father/ john_paul_ii/ encyclicals / documents/hf_jp - ii_enc_14091981_laboremexercens_po.html>. Acesso em 7 fev. 2012.

Mater et Magistra de 1961. Disponível em: <http://www.vatican.va /holy_father/john_xxiii/encyclicals/documents/hf_j- xxiii_enc_15051961_mater_ po.html>. Acesso em 17 jul. 2012.

Redemptoris Missio de 1990. A validade permanente do mandato missionário. $6^{\mathrm{a}}$ ed. São Paulo: Paulinas, 2003.

CNBB, Conferência Nacional dos Bispos do Brasil. Mobilidade Humana no Brasil: orientações pastorais. Brasília: CNBB, 2009.

COMBLIN, José. Pastoral Urbana: o dinamismo na evangelização. $3^{\mathrm{a}}$ ed. Petrópolis-RJ: Vozes, 2002.

Evangelização e missão profética da Igreja: novos desafios. $2^{\mathrm{a}}$ ed. São Paulo: Paulinas, 2005. 
Projeto Nacional de Evangelização (2004-2007): queremos ver Jesus Caminho, Verdade e Vida. $4^{\text {a }}$ ed. São Paulo: Paulinas, 2004.

COSTA, Jurandir Freire. O ponto de vista do outro: figuras da ética na ficção de Graham Greene e Phillip K. Dick. Rio de Janeiro: Garamond, 2010.

DOMINGUES, José Maurício. Interpretando a modernidade: imaginário e instituições. Rio de Janeiro: FGV, 2002.

DOWBOR, Ladislau. A reprodução social. vol. I. Petrópolis: Vozes, 2011.

FORTE, Bruno. Um pelo outro: por uma ética da transcendência. São Paulo: Paulinas, 2006.

FREITAG, Bárbara. Teorias da cidade. Campinas: Papirus, 2006.

GALANTINO, Nunzio. Dizer homem hoje: novos caminhos da antropologia filosófica. São Paulo: Paulus, 2003.

GASPARET, Murialdo. O rosto de Deus na cultura milenar dos ciganos. São Paulo: Paulinas, 1999.

GIDDENS, Anthony. As consequências da modernidade. São Paulo: UNESP, 1991.

GOITIA, Fernando Chueca. Breve história do urbanismo. Lisboa: Presença, 1992.

GUSDORF, Georges. A agonia da nossa civilização. São Paulo: Convívio, 1978.

HABERMAS, Jüngen. O futuro da natureza humana. São Paulo: Martins Fontes, 2004.

HAROUEL, Jean-Louis. História do Urbanismo. Campinas: Papirus, 1990

HERVIEU-LÉGER, Danièle. O peregrino e o convertido: a religião em movimento. Petrópolis-RJ: Vozes, 2008.

João Paulo II. Bula de Proclamação do Grande Jubileu do Ano 2000. Incarnationis Mysterium. Disponível em: <http://www.vatican.va/jubilee_ 2000/docs/ documents/hf_jpii_doc_30111998_bolla-jubilee_po.html>. Acesso em: 20 nov.

A peregrinação aos lugares relacionados com a História da Salvação. São Paulo: Paulinas, 1999.

LADARIA, Luis Francisco. O Deus vivo e verdadeiro: o mistério da Trindade. São Paulo: Loyola, 2005.

Introdução à Antropologia Teológica. São Paulo: Loyola, 1998. 
LEMOS, André. Cultura da Mobilidade. Porto Alegre: Revista FAMECOS, $\mathrm{n}^{\circ} 40$, dezembro de 2009, p.28-35.

LIBANIO João Batista. As lógicas da cidade: o impacto sobre a fé e sob o impacto da fé. São Paulo: Loyola, 2002.

MCC, Grupo Executivo Nacional do Movimento de Cursilhos de Cristandade do Brasil. Guia do Peregrino. Rio de Janeiro: MCC, 2003.

MERTON, Thomas. Na liberdade da Solidão. $2^{\text {a }}$ ed. Petrópolis: Vozes, 2002.

MIRANDA, Mário de França. Igreja e sociedade. São Paulo: Paulinas, 2009.

A Igreja numa sociedade fragmentada. São Paulo: Loyola, 2006.

2004.

A salvação de Jesus Cristo: a doutrina da graça. São Paulo: Loyola,

MOLTMANN, Jürgen. Teologia da Esperança: estudos sobre os fundamentos e as consequências de uma escatologia cristã. $3^{\text {a }}$ ed. São Paulo: Loyola, 2005.

MONDIN, Battista. O homem, quem é ele? Elementos de Antropologia Filosófica. 12a ed. São Paulo: Paulus, 1997.

MOSER, Antônio. O pecado: do descrédito ao aprofundamento. $4^{\mathrm{a}}$ ed. Petrópolis: Vozes, 2006.

MUlLER, Ivo (org.). Perspectivas para uma Nova Teologia da Criação. Petrópolis: Vozes, 2003.

MUMFORD, Lewis. A cidade na história: suas origens, transformações e perspectivas. $2^{a}$ ed. São Paulo: Martins Fontes, 1990.

NODARI, Paulo César \& CESCON, Everaldo. Os sacramentos da Igreja: subsídio teológico-pastoral para formar e educar na fé. São Paulo: Paulus, 2009.

OLIVEIRA, Manfredo Araújo de. Antropologia Filosófica Contemporânea: subjetividade e inversão teórica. São Paulo: Paulus, 2012.

Filosofia Transcendental e Religião: Ensaio sobre a Filosofia da Religião em Karl Rahner. São Paulo: Loyola, 1984.

PERGOLA, Giuliano Dello. Viver a cidade: orientações sobre problemas urbanos. São Paulo: Paulinas, 2000.

PRETTO, Hermilio. A teologia tem algo a dizer a respeito do ser humano? São Paulo: Paulus, 2003. 
RATZINGER, Joseph (Cardeal). O Sal da terra: o cristianismo e a Igreja Católica no limiar do Terceiro Milênio: um diálogo com Peter Seewald. Rio de Janeiro: Imago, 2005.

RICOEUR, Paul. Finitude et culpabilité, I L'homme Faillible. Paris: Aubier, 1960.

RIESMAN, David \& GLAZER Nathan \& DENNEY, Reuel. A multidão solitária. Um estudo de mudanças do caráter americano. São Paulo: Perspectiva, 1971.

ROLNIK, Raquel. O que é cidade. $3^{\text {a }}$ ed. São Paulo: Brasiliense, 1994.

RUBIO, Alfonso García (org.) \& AMADO, Joel Portella (org.). Fé Cristã e pensamento evolucionista: aproximações teológico-pastorais a um tema desafiador. São Paulo: Paulinas, 2012.

RUBIO, Alfonso Garcia. O encontro com Jesus Cristo vivo: um ensaio de cristologia para nossos dias. 14ª ed. São Paulo: Paulinas, 2010.

2008 .

A caminho da maturidade na experiência de Deus. São Paulo: Paulinas,

Unidade na pluralidade: o ser humano à luz da fé e da reflexão cristãs.

São Paulo: Loyola, 2001.

SANTOS, Boaventura Souza. A construção multicultural da igualdade e da diferença. Oficina do CES n.135. Janeiro 1999. Disponível em <http://www. ces.uc.pt/publicacoes/oficina/135/135pdf>. Acesso em 20 jul de 2012.

SANTOS, Milton. A Urbanização Brasileira. São Paulo: Hucitec, 1993.

SCIENCE, Chico (compositor). Afrociberdelia: Um Passeio No Mundo Livre. Chico Science \& Nação Zumbi, 1996.

SCOTT, John. Sociologia: conceitos-chave. Rio de Janeiro: Zahar, 2010.

SICRE, José Luíz. Profetismo em Israel: o profeta, os profetas, a mensagem. Petrópolis: Vozes, 2002.

SUSIN, Luiz Carlos. Mysterium Creationis. Um olhar interdisciplinar sobre o Universo. São Paulo: Paulinas, 1999.

TEIXEIRA, Luiz Caetano Grecco. Realidade virtual e testemunho real. Tempo e Presença, v. 20, 1998, nº 298, ISSN 1981-1810.

TOURAINE, Alain. Poderemos Viver Juntos? Iguais e Diferentes. São Paulo: Instituto Piaget, 1998. 
VALADIER, Paul. Des repères pour agir. Paris: Desclée de Brouwer-Bellarmin, 1977.

VIANNA, Oliveira. Evolução do Povo Brasileiro, 4.ed. Rio de Janeiro: José Olympio, 1956.

VORGRIMLER, Herbert. Karl Rahner: experiência de Deus em sua vida e em seu pensamento. São Paulo: Paulinas, 2006.

WÉNIN, André. O homem bíblico. São Paulo: Loyola, 2006. 